483

N54433

1908

\title{
ANALYSIS
}

OF THE

Departmental Estimate for 1908

OF THE

\section{DEPARTMENT OF PARKS}

(Borough of The Bronx).

October 9, 1907.

Bureau of Municipal Investigation and Statistics, Department of Finance. 
$\gamma$ 


\title{
ANALYSIS
}

OF THE

\section{Departmental Estimate for 1908}

\author{
OF THE
}

\section{DEPARTMENT OF PARKS \\ (Borough of The Bronx).}

October 9, 1907.

Bureau of Municipal Investigation and Statistics, Department of Finance.

$$
5190 \%
$$




$$
\begin{aligned}
& S B 483 \\
& N 5443
\end{aligned}
$$

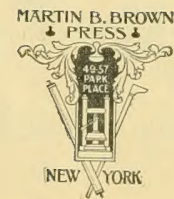

By firzohange

New Xask Pab. Iuby.

MAR 121934

(2136́3G) 


\title{
DEPARTMENT OF PARKS, BOROUGH OF THE BRONX.
}

\author{
Analysis of Departmental Estimate for 1908.
}

Hon. HERMAN A. METZ, Comptroller:

New York, October 9, 1907.

Dear Sir-I beg to transmit herewith a report giving the results of an analysis made under your directions, in the Bureau of Municipal Investigation and Statistics, of the departmental estimate for 1908 of the Commissioner of Parks, Borough of The Bronx.

\section{ADMINISTRATION.}

Salaries and Wages.

In the Budget for 1907 the allowance for Salaries and Wages of the administration force was provided in two separate funds, viz.: Administration, $\$ \mathrm{r} r, 100$, and Salaries of Chief Engineer and Employees, $\$ 16,032$, or a total of $\$ 27,130$. The Commissioner, in his departmental estimate, as originally transmitted to the Mayor as Chairman of the Board of Estimate and Apportionment, requested that appropriations be made for Igo8 as follows: Administration Account, \$13,150; Salaries of Chief Engineer and Employees, $\$ 20,440$; a total of $\$ 33.590$, or an increase of $\$ 6,460$ over the total 1907 Budget allowance. Undèr date of October 4, 1907, the Commissioner addressed to the Mayor a supplemental estimate, requesting that appropriation be made for the employment during 1908 of two additional Clerks, at $\$ 1,200$ per annum each, and a Stenographer and Typewriter at \$1,050 per annum, in the office of the Superintendent of Parks. This makes a total of $\$ 37,040$ requested for 1908 , or a net increase of $\$ 10,910$ over the Budget allowances for 1907 . The total expenditures for the salaries and wages of the administration force from the two salary appropriation accounts previously specified during 1906 were $\$ 26,025.88$. However, the fact has been disclosed in the course of this examination that it had been the custom, until a few months ago, to detail from time to time men from the labor force, whose compensation was paid from the Budget account for Maintenance and Construction, to do clerical work in the offices of the Commissioner, Superintendent of Parks and Chief Engineer. This practice having been discontinued by direction of the Muni- 
cipal Civil Service Commissioners, provision is asked to be made for the employment of two additional Clerks, at $\$ \mathrm{I}, 200$ each, in the Commissioner's office; a messenger at $\$ 1,200$, two Clerks at $\$ 1,200$ each and a Stenographer and Typewriter at $\$ \mathrm{I}, 050$ in the office of the Superintendent of Parks.

Continuing the adoption of the modified form of Budget for the several branches of the Department of Parks recommended by the Conference Committee on Budget, it is proposed to set up the Salaries and Wages account of the force connected with Administration under three separate headings, as follows:

A-Commissioner's office.

B-Superintendent's office.

C-Chiei Engineer's office.

\section{Account No, I-B-Salaries and Wages-Commissioner's Office.}

On the payroll of the Commissioner's office there may be placed the following:

\begin{tabular}{|c|c|c|}
\hline$=$ & $\begin{array}{c}\text { Present } \\
\text { Saląry Cost. }\end{array}$ & $\begin{array}{l}\text { Proposed } \\
\text { Salary for } \\
\text { I908. }\end{array}$ \\
\hline I Chief Clerk $\ldots \ldots \ldots \ldots \ldots \ldots \ldots \ldots \ldots \ldots \ldots \ldots \ldots \ldots \ldots$ & $\$ 2,40000$ & $\$ 2,400$ 00 \\
\hline 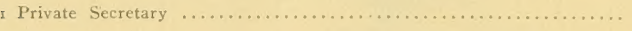 & 2,40000 & 2,50000 \\
\hline 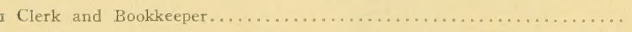 & 1,950 00 & 2,250 00 \\
\hline 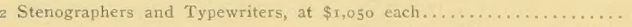 & 2,10000 & 2,40000 \\
\hline 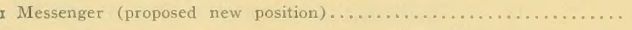 & $\ldots \ldots$ & $I, 20000$ \\
\hline 2 Clerks, at $\$ 1,200$ each (proposed new positions)................. & $\ldots \ldots$ & 2,40000 \\
\hline$\ldots \ldots \ldots \ldots \ldots \ldots \ldots \ldots \ldots \ldots \ldots$ & $\$ 8,850$ oo & $\$ 13,15000$ \\
\hline
\end{tabular}

The Commissioner says the proposed increase of $\$ 150$ in the salary of the Private Secretary is requested in order to equalize the salary of that official with that paid to the Secretary to the Commissioner in the Department of Parks, Boroughs of Brooklyn and Queens. The increase of $\$ 300$ in the salary of the Clerk and Bookkeeper is to restore that official to his former grade, his salary having been reduced under the provisions of chapter 435 of the Laws of 1902 . The incumbent has been in the service of the department since 1898 , and the responsibilities and duties of the office have so increased that the proposed restoration of his former salary grade seems only a reasonable request.

The increases proposed in the salaries of the Stenographers and Typewriters of $\$ 150$ each are requested for the reason that these employees have been in the department several years, and there have been no increases in their salaries during the past three years. The salary of the Telephone Switchboard Operator, $\$ 600$ a year, is now paid from Maintenance and Construction account. 
The new positions, appropriations for which are asked to be made, are those of two Clerks, at $\$ 1,200$ each, and one Messenger, at $\$ 1,200$. The request for an increased clerical force to assist the Bookkeeper would appear to be justified, but the character of the work to be done is such that it could be performed as well by Clerks at $\$ 900$ a year as by $\$ 1,200$ men. Such duties as would ordinarily be assigned to a Messenger in this department should be satisiactorily performed by an Office Boy.

An allowance of $\$ 12,250$ is recommended for Salaries and Wages in the office of the Commissioner, to be divided as follows:

Recommended Salary Allowances for 1908 .

I Chief Clerk

$\$ 2,400$ 00

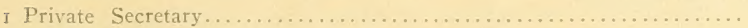

2,50000

I Clerk and Bookkeeper................................ 2,250 00

2 Stenographers and Typewriters, at $\$ 1,200$ each.................. 2,400 00

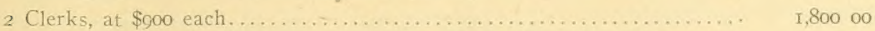

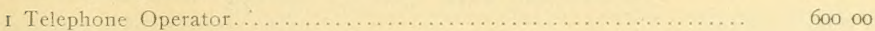

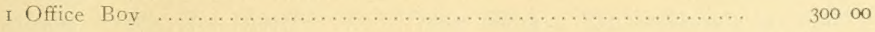

Total ...................................... $\$ 12,25000$

\section{Account No. 2-B-Salaries and Wages-Superintendent's Office.}

Below is given a tabulation showing the present organization of the Superintendent's office, with the salaries now paid and the proposed salaries for Igos:

\begin{tabular}{|c|c|c|}
\hline 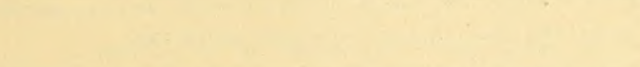 & $\begin{array}{c}\text { Present } \\
\text { Salary Cost. }\end{array}$ & $\begin{array}{l}\text { Próposed } \\
\text { Salary for } \\
\text { 1908. }\end{array}$ \\
\hline I Superintendent & $\$ 3,00000$ & $\$ 3,000 \quad 00$ \\
\hline 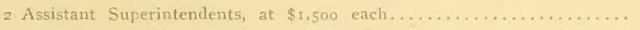 & 3.00000 & 3.00000 \\
\hline 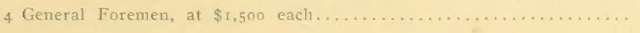 & 6,00000 & 6,00000 \\
\hline 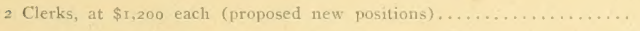 & …... & 2,400 o0 \\
\hline i Stenographer and Typewriter (proposed new position)..$\ldots \ldots \ldots \ldots$ & $\ldots \ldots$ & 1,05000 \\
\hline Total............... & $\$ 12,000$ 00 & $\$ 15,450^{\prime} 00$ \\
\hline
\end{tabular}

Of the several positions specified above, the salaries of the Superintendent, the Assistant Superintendents and the General Foremen are now and have previously been paid from the Budget appropriations account known as Maintenance and Construction. The clerical work in the office of the Superintendent has been in the past performed by men detailed from the laboring force, and the Commissioner states that in order to effect a proper working administration force, and further to comply with the 
requirements of the Civil Service laws he has asked for the creation of these additional clerkships and a new position for a stenographer and typewriter.

To further carry out the recommendations of the Conference Committee on Budget it is here suggested that compensation of the two Assistant Superintendents and four General Foremen be included in the proposed appropriation account for Salaries and Wages of the Superintendent's office. The establishment of one new clerkship at $\$ 900$ is recommended. There are now three Stenographers and Typewriters connected with the administration, and your Examiner suggests that this force should be sufficient, if their labors were judiciously divided to meet all the requirements for dictation, typewriting and correspondence of the offices of Commissioner, Superintendent and the Chief Engineer.

It is recommended that the allowance for Salaries and Wages-Office of the Superintendent, be $\$ \mathrm{I} 2,900$, divided as follows:

Recommended Salary Allowances for Igo8.

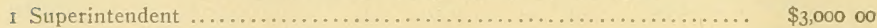

2 Assistant Superintendents, at $\$ 1,500$ each.................... 3,00000

4 General Foremen, at $\$ 1,500$ each.......................... 6,00000

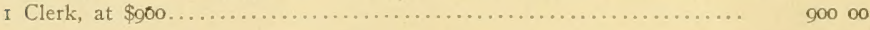

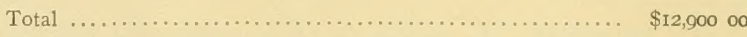

Account No. 3-B-Salaries and Wages-Engineer's Office.

Herewith is presented a summary showing the present positions and the salaries paid in the Engineer's office, with those proposed to be paid during 1908:

\begin{tabular}{|c|c|c|}
\hline$=$ & $\begin{array}{c}\text { Present } \\
\text { Salary Cost. }\end{array}$ & $\begin{array}{c}\text { Proposed } \\
\text { Salary for } \\
1908 \text {. }\end{array}$ \\
\hline x Chief Engineer .............. & $\$ 4,000$ o0 & $\$ 4,00000$ \\
\hline 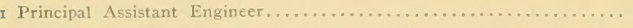 & 2,10000 & 2,10000 \\
\hline 2 Assistant Engineers, at $\$ 2,100$ each................ & 4,20000 & 4,20000 \\
\hline I Horticultural Draughtsman & $x, 80000$ & 1,95000 \\
\hline r Rodman....... & 2,10000 & 2,10000 \\
\hline 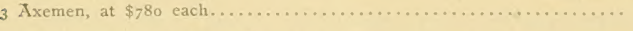 & 2,34000 & 2,34000 \\
\hline 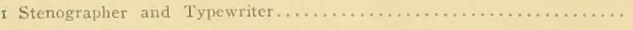 & 1,05000 & 1,20000 \\
\hline I Leveler & $\ldots \ldots$ & 1,35000 \\
\hline Total....... & $\$ 17,590$ 00 & $\$ 19,24000$ \\
\hline
\end{tabular}


The position of Leveler, at $\$ 1,350$, was established and a man appointed subsequent to the date of transmitting the Departmental Estimate for 1908. The increase of $\$ 150$ in the salary of the Horticultural Draughtsman has also been made since the estimate for 1908 was furnished.

The only proposed new position is that for a Clerk, at $\$ 1,200$ per annum. It is necessary, the Commissioner says, to establish a clerkship in the Engineer's bureau, so as to permit of the employment on field work continuously of one of the Assistant Engineers, much of whose time is now taken up with office work, when his services should be utilized on teclmical engineering work in the office as well as in the field.

Much of the compensation of the engineering force is properly chargeable to Corporate Stock appropriations for the construction and improvement of parks, parkways and public places under the jurisdiction of the department, and for the purposes of the Budget allowances it has been suggested by the Conference Committee on Budget that there be included therein only the salaries of the office and supervisory forces, leaving the cost of the technical corps to be charged against Corporate Stock appropriations, authorized from time to time for specific construction work and improvements. It is therefore recommended that an allowance be made in the Budget for 1908 , to be divided as follows:

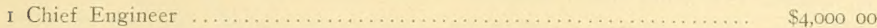

I Principal Assistant Engineer............................ 2, 100 oo

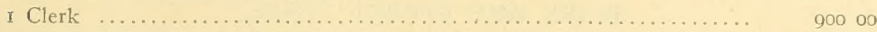

I Stenographer and Typewriter.......................... I,200 00

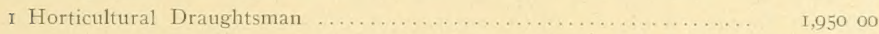

Total .................................... $\$ \$_{10,450} 00$

A summary of the Salaries and Wages Budget appropriation accounts for the offices of the Commissioner, Superintendent and Chief Engineer, as herein recommended would show a total of $\$ 35.000$ for administration purposes, as follows:

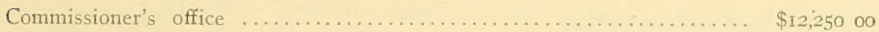

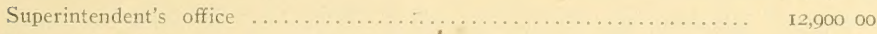

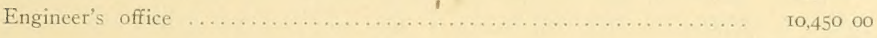

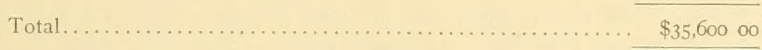

This represents an increase of $\$ 8,470$, as compared with the Budget allowances for Administration salaries in 1907 , and will reduce the requirements of the Budget account for Maintenance and Construction $\$ 9,600$, this amount now being paid to two Assistant Superintendents, two General Foremen and one Telephone Operator now being charged to that account. The account for the Engineer's office, if paid at $\$ 10,450$, will represent a decrease of $\$ 5,580$ as compared with the amount included in the Budget for 1907 . 
In the Budget for 1907 an appropriation of $\$ 1,500$ was made for Supplies and Contingencies. In 1906 the expenditures were $\$ 1,600$, of which $\$ 700$ was for telephone service and about $\$ 900$ for office supplies and contingencies, some of the office supplies having been charged to Maintenance and Construction account.

The modified Budget form for 1908 provides for a segregation of this account as follows:

Supplies, Contingencies, Telephone, Rental of.

\section{Account No. 4-B-Supplies.}

An allowance of $\$ 500$ for office supplies is recommended.

Account No. 5-B-Contingencies.

An allowance of $\$ \mathrm{r}, 000$ is recommended for 1908 , this account being intended for postagc, carfares, automobile repairs and other contingent expenses related to administration.

Account No. 6-B-Telephone, Rental of.

The estimated cost of telephone service for 1908 is $\$ 800$. In 1906 the cost was $\$ 700$. An allowance of $\$ 750$ is recommended.

\section{II.-MAINTENANCE OF PARKS, BOULEVARDS, DRIVES, STONE WORK AND STREET TREES.}

Parks and Boulevards-The accounts now known as Maintenance and Construction and Forestry Work, for all the purposes of which the sum of $\$ 293.774 .68$ was provided in the Budget for 1907 , is to be subdivided in accordance with the revised Budget form as follows:

(a) Salaries and Wages.

(b) Hired Teams and Carts, Rnad Machines and Rollers

(c) Equipment, Repairs and Renewal, Stupplies.

(d) Consumable Supplies

In the Budget for 1907 the appropriation for all purposes for which the account known as Maintenance and Construction is now $115 e d$, was $\$ 289,774.86$, and for the Forestry Work account $\$ 4,000$ was provided, making a total of $\$ 293,774.86$, In 1906 the expenditures from these two appropriation accoints were from Maintenance and Construction, $\$ 246,450$, and Forestry Work, $\$ 5,000$, a total of $\$ 25 I, 450$,

In response to a request from the Commissioner addressed to the Board of Aldermen and the Board of Estimate and Apportionment, additional appropriations, part of which were to be used for maintenance purposes during Igo6, Special Revenue Bonds were authorized to be issued amounting to $\$ 101,000$. Of this amount $\$ 20,000$ was for the care of trees in City streets, $\$ 7,000$ for the purchase of new iron benches or settees, $\$ 4,000$ for an automobile and $\$ 70,000$ to cover estimated deficiencies in the 
maintenance account. Subsequently the maintenance account was further increased by a transfer of $\$ 7,963.07$ from other Budget approptiation accounts in which there existed unexpended balances.

Thus during Ino6 there was appropriated, and otherwise made available for mainterance purposes, $\$ 336,413.07$, as follows:

Budget Appropriations-

Mraintenance and Construction account..................... \$246,450 00

Forestry Work account............................ 5,00000

Special Reventse Bond Funds-

For deficiencies in maintenance account................... 70,00000

To purchase park benches or settees..................... 7,000 00 By transfers from unexpended balances in other appropriation accounts. 7,96307

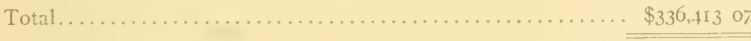

The Commissioner under date of January 30, 1907, again made application to the Board of Alfermen for an issue of Special Revenue Bonds, this time asking that $\$ \mathrm{r} 40, \mathrm{coo}$ be provided, in anticipation of an estimated deficit which was expected to occur in the 1907 Budget appropriation maintenance accounts, which aggregated $\$ 293,774.86$, as previously stated.

The Chairman of the Finance Committec of the Board of Aldermen requested the Comptroller to cause to be made an eximination and report as to the financial needs of the Department of Parks, Lorough of The Broux, and such examination and report was made under your direction by the Burean of Municipal Investigation and Statistics. In the report, which was transmited, with the Comptroller's approval, to the Chaiman of the Finance Committee of the Board of Aldermen, it was recommended that authority be given for an issue of Special Revenue Bonds to the amount of $\$ 46,000$ to provide funds to cover a probable deficit in the maintenance appropriations of the Department. It was not, however, until October I, r907, that the Board of Aldermen acted upon the request of the Commissioner. On that date the recontmendation contained in the report of the Burcau of Numicipal Investigation and Statistics was approved, the resolution therefor being now before the Board of Estimate and Apportionment for concurrence. Assuming that the resolution will receive the concurrence of the Board of Estimate and Apportionment, it will be seen that the amount available for maintenance purposes during 1907 will be $\$ 339,77+86$, divided as follows:

Budget appropriation, Maintenance and Construtction account......... \$289.774 86 Budget appropriation, Forestry Work account................ 4,000 00 Special Revenuc Bond fund for deficiencies in maintenance accounts... 46,000 oo 
It will be seen that $\$ 339,774.86$, the amount avalable for maintenance in 1907 , exceerls that provided and made available for similar purposes last year, $\$ 336,413.07$, by $\$ 3.361 .79$.

Of the amount $\$ 336.413 .0 \%$, made available for 12 se in 1906 , an analysis of the expenditures therefrom shows that the total disbursements were $\$ 335.408 .99$, divided as follows:

\begin{tabular}{|c|c|c|c|c|c|}
\hline & $\begin{array}{c}\text { From } \\
\text { Budget } \\
\text { Jccount, } \\
\text { Maintenance } \\
\text { and } \\
\text { Construction. }\end{array}$ & $\begin{array}{l}\text { From } \\
\text { Budget } \\
\text { Account } \\
\text { for } \\
\text { Forestry } \\
\text { Work. }\end{array}$ & $\begin{array}{l}\text { From } \\
\text { Special } \\
\text { Revenue } \\
\text { Bond Fund } \\
\text { for } \\
\text { Deficit. }\end{array}$ & $\begin{array}{l}\text { From } \\
\text { Special } \\
\text { Revenue } \\
\text { Pond Fund } \\
\text { for Penches, } \\
\text { Etc. }\end{array}$ & Total \\
\hline Payrolls of Department force... & $\$ 204,179$ or & $\$ 4,84695$ & $\$ 60,80720$ & $\ldots \ldots$ & $\$ 269, \$ 33$ I \\
\hline l'ayrolls of hired teams, horses & & & & & \\
\hline and carts $\ldots \ldots \ldots \ldots \ldots \ldots$ & $19,490 \quad 12$ & 12375 & $9,0912.4$ & $\ldots \ldots$ & $28.705 \mathrm{I}$ \\
\hline$\ldots \ldots \ldots \ldots \ldots$ & 29.87472 & $\ldots \ldots$ & . . . . & $\ldots \ldots$ & $29.87+7$ \\
\hline Park benches ot settees........ & $\ldots \ldots$ & $\ldots \ldots$ & $\ldots \ldots$ & $\$ 6,99600$ & $\$ 6,996$ or \\
\hline Total........... & $\$ 253.54385$ & $\$ 4,97070$ & $\$ 69,898+4$ & $\$ 6,996$ oo & $\$ 335,408$ \\
\hline
\end{tabular}

\section{Accounts Nos. 7-B and 8-B-Salaries and Wages, and Hired Teams and Carts, Road Machines and Rollers.}

Special examination has been made of the payroll payments durirg 1 gor and to August 3I, 1907, to ascertain what may be the reasonable requirements of the department for labor. Complete schedules have been prepared giving in detail the amounts expended for salaries and wages of departmental employees and hired teams and carts. road machines and rollers, chargeable to the appropriation accounts known as Maintenance and Construction and Forestry. Work, as well as to the several Special Reveme Bond Funds for the maintenance of parks and boulcvards, but not including appropriations made for the care of trees in city streets. These schedules will be found appended to this report and marked, viz.: Payroll Schedirles Nos. I-B, 2-B, 3-B, 6-B, 7-B, I1- B, 12-B, I3-B, I7-B and I8-B.

Summarics of the weekly payroll schedules previously referred to, showing the amounts expended monthly on account of departmental labor fron January I, 1906, to August $3 \mathrm{~T}, 1907$, are given in the following tabulations:

\section{Monthly Summary of Pay-roll Schedule No. I-B.}

Showing payments by months on account of payrolls for departmental employees during 1906, engaged in Parks and Boulevards, and charged to Budget appropriation account, Maintenance and Construction. 


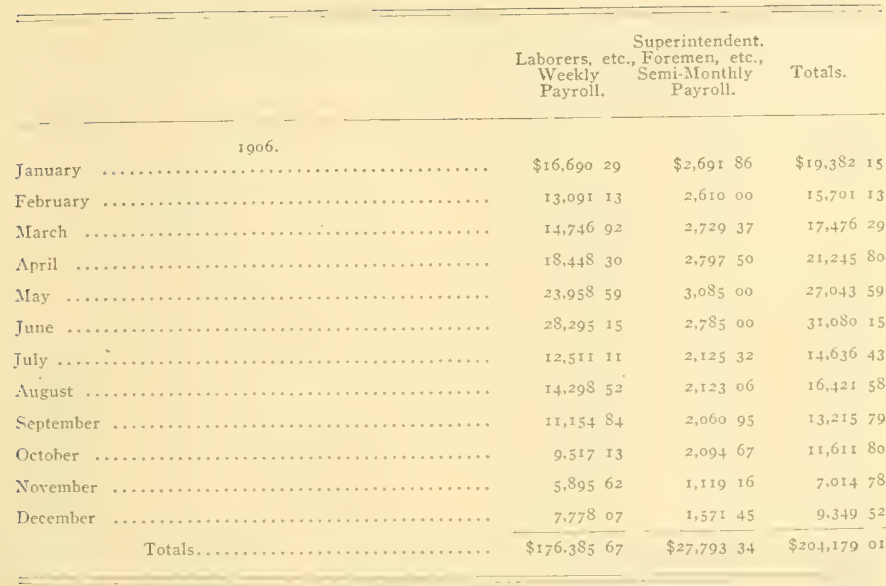

Monthly Summary of Pay-roll Schedule No. 2-B.

Showing payments by montlis on account of payrolls for department labor engaged in Parks and Boulevards and charged to Forestry Work Budget appropriation account.

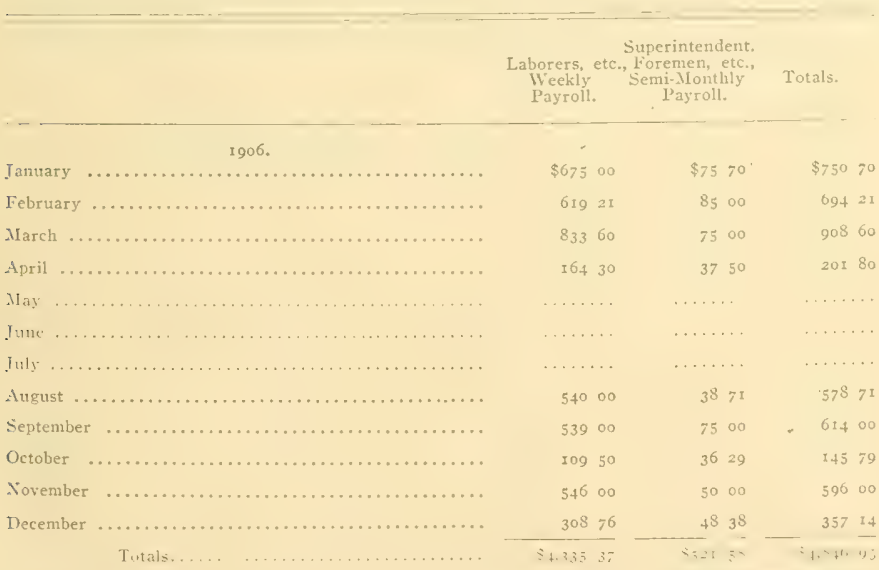


Monthly Summary of Pay-roll Schedule No. 3-B.

Showing payments monthly on account of payrolls for department labor engaged in Parks and Boulevards, charged to Special Revenue Bond Fund for Deficiencies in Maintenance Accounts.

\begin{tabular}{|c|c|c|c|c|}
\hline & & $\begin{array}{l}\text { Laburers, etc., } \\
\text { Weekry } \\
\text { Payroll. }\end{array}$ & $\begin{array}{l}\text { Superintendent. } \\
\text { Foremen, etc., } \\
\text { Semi-Monthly } \\
\text { Payroll. }\end{array}$ & Totals. \\
\hline \multicolumn{5}{|c|}{1906.} \\
\hline July $\ldots .$. & $\ldots \ldots \ldots+\cdots \cdots \cdots \cdots$, & $\$ 10,16584$ & $\$ 80000$ & $\$ 10.96584$ \\
\hline August $\ldots$ & $\ldots \ldots \ldots \ldots \ldots$ & $12,493 \quad 32$ & 82000 & $x 3.3 \times 3.32$ \\
\hline September & 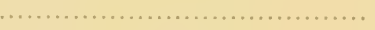 & 8,90077 & 81250 & 9,71327 \\
\hline October .. & $\ldots \ldots \ldots \ldots$ & 6,02374 & $761 \quad 28$ & $6,785 \quad 02$ \\
\hline November & 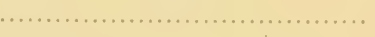 & $8,771 \quad 75$ & 1,71750 & $10,489 \quad 25$ \\
\hline December. & & $8,0963 x$ & $x, 444 \quad 19$ & $9.540 \quad 50$ \\
\hline- & Totals.......... & $\$ 54,45$ I $\quad 73$ & $\$ 6,355 \quad 47$ & $\$ 60,80720$ \\
\hline
\end{tabular}

\section{Monthly Summary of Pay-roll Schedule No. 6-B.}

Showing payroll payments, January I to Augnst 3r, 1907, for services of Superinrendent, Engineers, Foremen, Laborers, etc., in Parks and Boulevards, charged against Budget appropriation account, Maintenance and Construction.

Superintendent.
Laborers, etc., Foremen, etc,
Weekly Semi-Monthly
Payroll. Totals.

1907

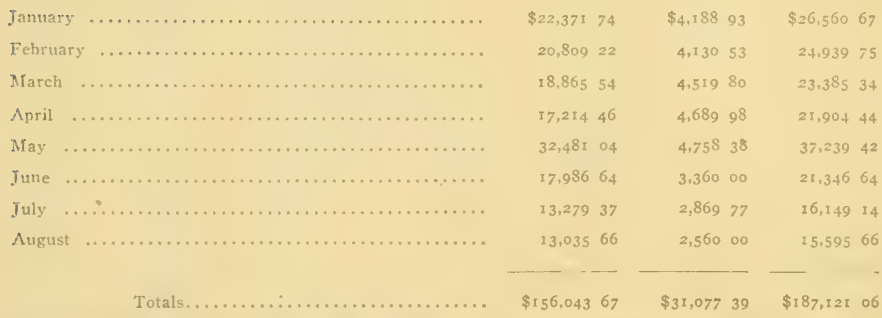


Monthly Summary of Pay-roll Schedule No. 7-B.

Showing payroll payments, January I to August 31, 1907. for scrvices of Superintendent, Engineers, Foremen, Laborers, etc., in Parks and Boulevards, charged against Budget appropriation account, Forestry Work.

$$
\begin{array}{ccc} 
& \text { Superintendent. } \\
\text { Laborers, etc., Foremen, etc., } & \text { Totals. } \\
\text { Weekly } & \text { Semi-Monthly } & \text { Totall. } \\
\text { Payroll. } & \text { Payroll. } &
\end{array}
$$

1907.

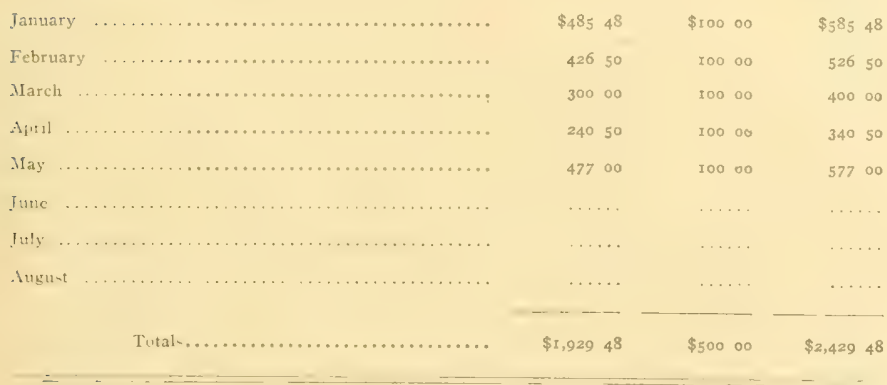

Recapitulations of the monthly summaries for payroll disbursements for department employees in 1906 and 1907 on account of Maintenance of Parks and Boulevards are herewith given:

\section{Salary and Wages Cost (Department Employees) (January I to December 3 I,}

\begin{tabular}{|c|c|c|c|c|}
\hline & & $\begin{array}{c}\text { From Budget } \\
\text { Appropriations. }\end{array}$ & $\begin{array}{c}\text { From } \\
\text { Special Revenue } \\
\text { Bond Fund } \\
\text { for Deficiency. }\end{array}$ & Total. \\
\hline \multicolumn{5}{|l|}{ s9o6. } \\
\hline January & 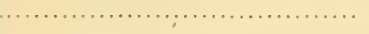 & $\$ 20,132 \quad 85$ & & $\$ 20,1_{32} 8_{5}$ \\
\hline Vebruary & 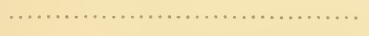 & 16,39534 & & 16,39534 \\
\hline M.utel: & $\cdots$ & $18,3 \times 4 \times 2$ & $\cdots \cdots$ & 18,38489 \\
\hline April $\ldots$ & $\ldots \ldots \ldots \ldots \ldots \ldots \ldots \ldots \ldots \ldots \ldots \ldots \ldots \ldots \ldots \ldots \ldots \ldots \ldots$ & 21,44760 & . . . . . & 21,44760 \\
\hline May & 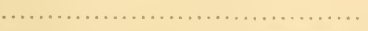 & 27,04359 & & $27,0+3 \quad 59$ \\
\hline
\end{tabular}
1906). 


\begin{tabular}{|c|c|c|c|c|}
\hline \multirow{2}{*}{\multicolumn{2}{|c|}{ Ftne $\ldots \ldots \ldots \ldots \ldots \ldots \ldots \ldots \ldots \ldots \ldots \ldots \ldots \ldots$}} & \multirow{2}{*}{$\begin{array}{c}\begin{array}{c}\text { From Budget } \\
\text { Appropriations. }\end{array} \\
\$ 31,0 \text { \$o } \text { I5 }\end{array}$} & $\begin{array}{c}\text { From } \\
\text { Special Revenue } \\
\text { Bond Fund } \\
\text { for Deficiency. }\end{array}$ & Total. \\
\hline & & & $\ldots \ldots \ldots$ & $\$ 31,0$ So I5 \\
\hline July & $\ldots \ldots \ldots \ldots \ldots \ldots \ldots \ldots \ldots \ldots \ldots \ldots$ & $14,636,43$ & $\$ 10,965 S_{4}$ & $25,602 \quad 27$ \\
\hline August .. & $\ldots \ldots \ldots \ldots \ldots \ldots \ldots \ldots \ldots \ldots \ldots \ldots \ldots$ & 17,00029 & $13.313 \quad 32$ & $30,3+36 \mathrm{r}$ \\
\hline September & $\ldots \ldots \ldots \ldots \ldots \ldots \ldots \ldots \ldots \ldots \ldots \ldots \ldots$ & 13,82979 & 9.71327 & 23.543 o6 \\
\hline October & $\ldots \ldots \ldots \ldots \ldots \ldots \ldots \ldots \ldots \ldots \ldots$ & 11,75759 & $6,-7 S_{5} \quad 02$ & 18,54261 \\
\hline November & $\ldots \ldots \ldots \ldots \ldots \ldots, n_{n} \ldots \ldots \ldots \ldots$ & $7,610,78$ & $10,489 \quad 25$ & $18,100 \quad 03$ \\
\hline 1)ecember & $\ldots \ldots \ldots \ldots \ldots \ldots \ldots \ldots \ldots \ldots \ldots \ldots$ & 9.70666 & $9.5 \div 0 \quad 50$ & $19.247 \quad 16$ \\
\hline & Total......................... & $\$ 209,02596$ & $\$ 60,80720$ & $\$ 269, \$ 33$ 16 \\
\hline
\end{tabular}

\section{Salary and Wages Cost (Department Employees Engaged in Parks and Boulevards) (January I to August $3 \mathrm{x}$, 1907).}

1907.

From Budget Appropriation Accounts.

Jammity $\$ 27, I_{7} 6$ is

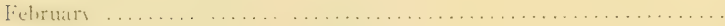
$25.466 \quad 25$

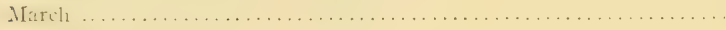
23.78534

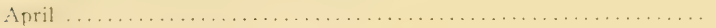
22,24494

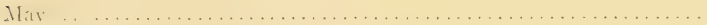
$37 . \operatorname{Sic}+2$

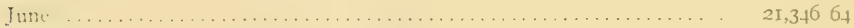

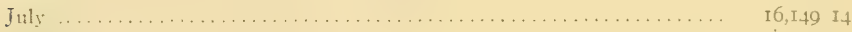

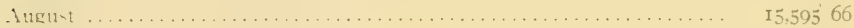

Tutal ............................. $\$$

In order that there may be presented an intelligible idea of the actual charges of all kinds incident to maintenance during 1906 and 1907 , except supplies, which will be discussed separately, monthly summaries have also been made of the expenditures from Budget Accounts and Special Revemue Bond Funds for hired teams and carts, road machines and rollers. These summaries are herewith given: 
Monthly Summary of Pay-roll Schedule No. II-B.

Showing Payroll Payments Monthly During 1906 for Hired Teams, Horses and Carts in Parks and Boulevards from Budget Appropriation Account, XIaintenance and Construction.

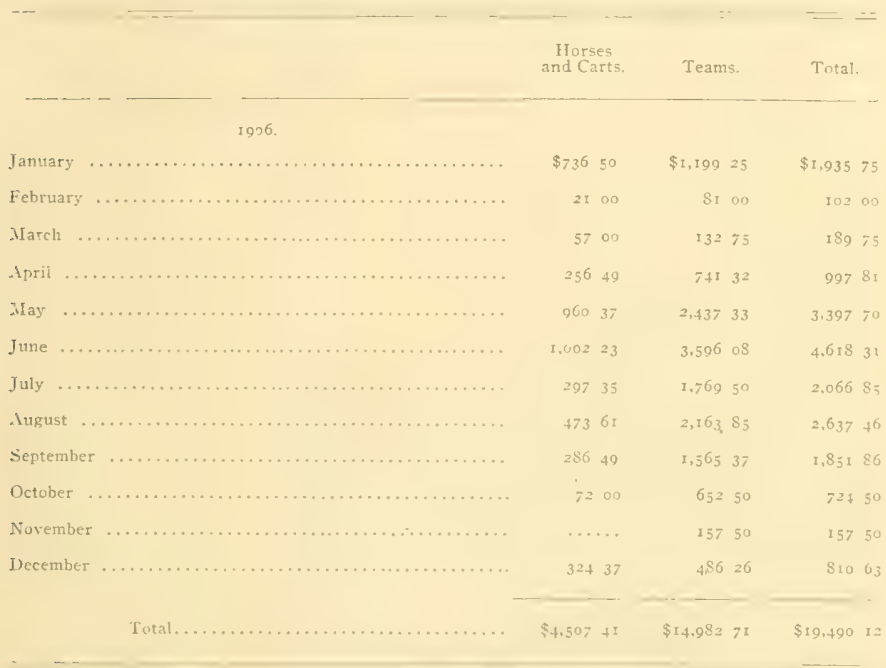

Menthly Summary of Pay-roll Schedule No. I2-B.

Slowing payroll payments monthly during 1906 for hired teams, horses and carts, in Parks and Boulevards, from Budget appropriation account, Forestry- Work.

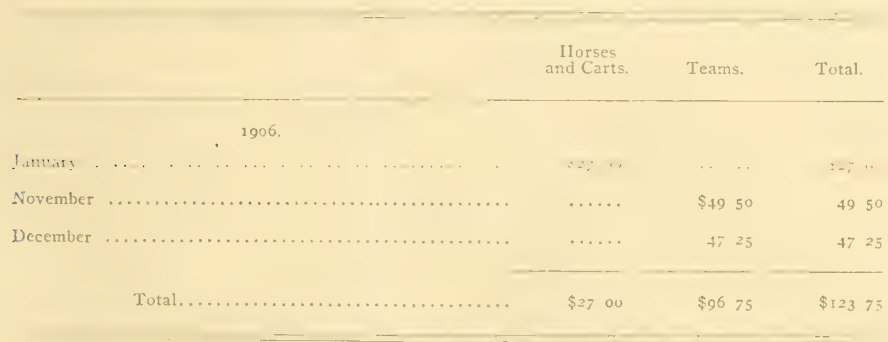


Monthly Summary of Pay-roll Schedule No. r3-B.

Showing payroll payments monthly during 1906 for hired teams, horses and carts, in Parks and Boulevards, from Special Revenue Bond Fund to meet deficiencies in Budget appropriation account.

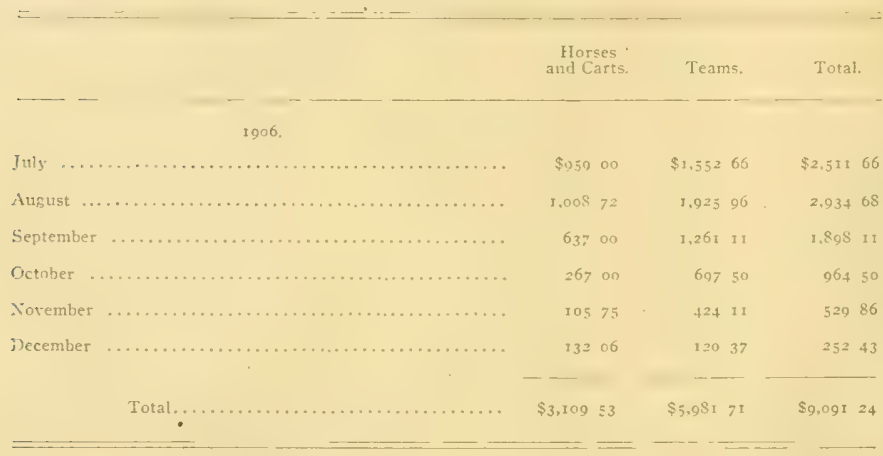

Monthly Summary of Pay-roll Schedule No. I7-B.

Showing monthly payroll payments, January I to August I, 1907, for hired teams, horses and carts, in Parks and Boulevards, charged against Budget appropriation account, MIaintenance and Construction.

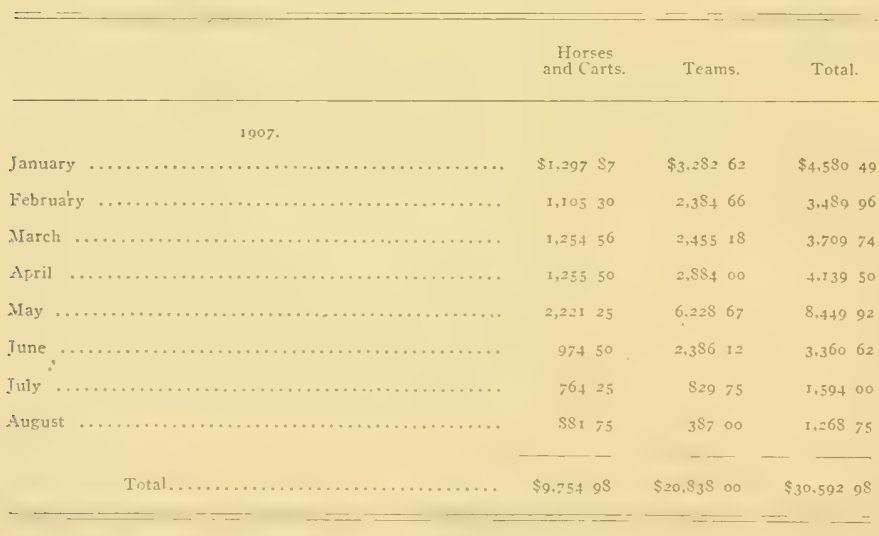


Monthly Summary of Pay-roll Schedule No. I8-B.

Showing monthly payroll payments, January I to August 3I. 1907, for hired tcams, horses and carts, in Parks and. Boulevards, charged against Budget appropriation account, Forestry Work.

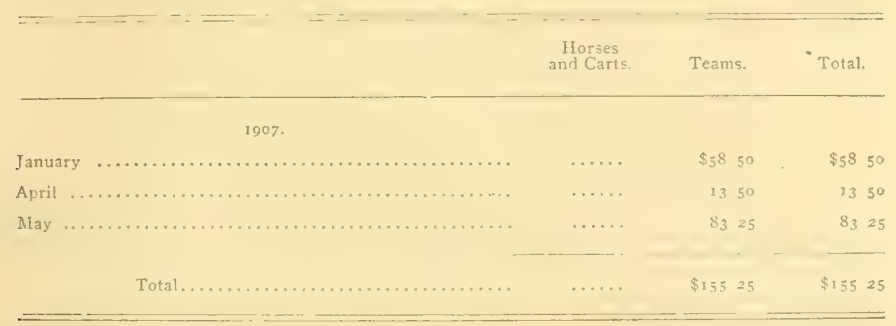

Summarized Statement of the Labor Charges for Maintenance of Parks and Boulevards, rgo6-rgo7 (to August 3r).

Following is a summarized statement of all the maintenance charges for labor during 1906 and 1907, whether for payrolls of departmental employees or for hired teams, horses and carts, and from which may be drawn conciusions as to the requirements of the two proposed new Budget appropriation accounts for Igo8, viz:

Parks and Boulevards-

Salaries and Wages.

Hired Teams and Carts, Road Machines and Rollers. 
January

February

March

April

May

June

July

August

September

October

November

December 
tenance Accounts, Parks and Boulevards, Ig06 and 1907 (to August 3r).

\begin{tabular}{|c|c|c|c|c|c|}
\hline \multicolumn{2}{|l|}{$\overbrace{\ldots . .}^{1906 .}$} & \multicolumn{2}{|c|}{ To August 31, 1907. } & \multirow[b]{2}{*}{$\begin{array}{l}\text { Total All } \\
\text { Labor } \\
\text { Charges for } \\
\text { Maintenance, } \\
\text { r9o6. }\end{array}$} & \multirow{2}{*}{$\begin{array}{c}\text { Total All } \\
\text { Labor } \\
\text { Charges for } \\
\text { Maintenance } \\
\text { to August } 31, \\
\text { 1907. }\end{array}$} \\
\hline $\begin{array}{c}\text { Salary and Wage } \\
\text { Cost of } \\
\text { Departmental } \\
\text { Employees. }\end{array}$ & $\begin{array}{l}\text { Hired Teams, } \\
\text { Carts, etc. }\end{array}$ & $\begin{array}{c}\text { Salary and Wage } \\
\text { Cost of } \\
\text { Departmental } \\
\text { Employees. }\end{array}$ & $\begin{array}{l}\text { Hired Teams, } \\
\text { Carts, etc. }\end{array}$ & & \\
\hline$\$ 20,13285$ & $\$ 1,96275$ & $\$ 27,146$ I5 & $\$ 4,63899$ & $\$ 22,09560$ & $\$ 3 x, 785 \quad x 4$ \\
\hline $16,395 \quad 34^{\prime}$ & 10200 & $25,466 \quad 25$ & 3,48996 & $16,497 \quad 34$ & 28,95621 \\
\hline $18,3^{84} 89$ & 18975 & $23,785 \quad 34$ & 3,70974 & $x 8,574 \quad 64$ & $27,495 \quad 08$ \\
\hline 21,44760 & 99781 & 22,24494 & 4,15300 & $22,445 \quad 41$ & 26,39794 \\
\hline 27,04359 & $3,397 \quad 70$ & $37,8 \times 6,42$ & $8,533 \quad 17$ & $30,441 \quad 29$ & $46,349 \quad 59$ \\
\hline $31,080 \times 5$ & $4,628 \quad 31$ & 21,34664 & $3,360 \quad 62$ & $35.698 \quad 46$ & 24,70726 \\
\hline $25,602 \quad 27$ & $4,5785 t$ & $16,149 \quad 14$ & $x, 59400$ & $30,180 \quad 78$ & $17,743 \quad 14$ \\
\hline $30,3136 \mathrm{I}$ & $5.572 \quad 14$ & 15.59566 & $x, 268 \quad 75$ & 35,88575 & $16,8644 \mathrm{I}$ \\
\hline 23,543 o6 & $3,749 \quad 97$ & ........ & $\ldots \ldots \ldots$ & $27,293 \quad 03$ & ....... \\
\hline $18,5,426 \pi$ & $\mathrm{x}, 68900$ & $\cdots \cdots \cdots$ & $\cdots \cdots \cdots$ & $20,23 \times 61$ & $\ldots \ldots$ \\
\hline $18,100 \quad 03$ & 73686 & 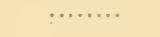 & ......... & 18,83689 & $\cdots \cdots \cdots$ \\
\hline $19,247 \quad 16$ & $\mathrm{I}, \mathrm{x} I 03 \mathrm{I}$ & $\cdots \cdots \cdots$ & $\ldots \ldots \ldots$ & 20,35747 & $\cdots \cdots \cdots$ \\
\hline$\$ 269,833 \quad 16$ & $\$ 28,705 \mathrm{II}$ & $\$ 189,550 \quad 54$ & $\$ 30,748=23$ & $\$ 298,538 \quad 27$ & $\$ 220,298 \quad 77$ \\
\hline
\end{tabular}


In explanation of the fact that the payroll disbursements for the first five months of 1907 ranged from $\$ 26,397.94$, the minimum monthly charge in April, to $\$ 46,349.59$, the maximum monthly expenditure in May, notwithstanding the Board of Aldermen had taken no action on the request of the department for an additional maintenance appropriation of $\$ 1$ to,000 in Special Revenue Bonds, the Commissioner said to your Exaniner that during the early months of the ycar it was found necessary to make many extraordinary expenditures for labor, in order to bring into public use certain parks and public places which had not previously been properly maintained, owing to insufficient funds, and which had in consequence greatly deteriorated.

On the payrolls during the month of September, 1907, the Commissioner says, there were approximately $6_{30}$ men, whose compensation was charged to all accounts. The highest number of men employed during the current year, he said, was approximately 700 . The Commissioner states that the improved park acreage in the Borough of The Bronx is about 870 acres and 63 -1o miles of parkways, 126 acres of "improved woodlands" and 28 acres of skating ponds and lakes requiring attention in winter. The Commissioner gives it as his judgment that it will require not less than $\$ 420,000$ for labor and wages of departmental employees, hired teams, horses, carts and supplies, to properly maintain these areas in 1908. The amount available for Igoy (providing the Board of Estimate and Apportionment approves the Special Revenue Bond fund issue of $\$ 46.000)$, as has previously been shown, is $\$ 339,774.86$.

The Commissioner's estimate of $\$ 420,000$ required for 1908 is an increase of $\$ 80$,225. I. over that made available in I007. Of the increased amount an analysis of the labor schedule submitted with the departmental estimate shows \$29.532.50 are asked for to provide for the employment of Laborers, Drivers, Carpenters, Painters and hired teams, horses and carts for an increased number of days, and $\$ 45.450$ to provide for the employment of an increased number of Foremen, Assistant Foremen, Laborers, the balance of the increase asked for being for supplies.

It having appeared from facts disclosed in connection with this examination that the work of maintenance and construction and improvement of parks, boulevards, drives, etc. (much of which is still in process of development) is correlated to such a degree that if has been deemed wise to include in this report an analysis of the payroll charges for work performed by department employees and hired teams, carts, etc., charged to the several Corporate Stock appropriations which were available during 1906-1907 for the construction, improvement and permanent betterment of parks, boulevards, etc.

That the Budget appropriation and Corporate Stock accounts made available during the past two years have been made to bear a close relation to each other would seem to be assured by an examination of the weekly payments for labor and hired teams charged to the several Budget, Revente Bond and Corporate Stock accounts, which will be found in detail attached to this report. It will be scen that, for the 
most part, while the amounts severally charged weekly to the various accounts available varied considerably; the total weekly charges were more steady and uniform in amount.

It seems that the regular maintenance account provided by tax levy for the Department of Parks, Borough of The Bronx, has, in contradistinction to those of the other branches of the Department of Parks, for several years past been designated as "Maintenance and Construction Account." It is stated that this title was first given the Budget account for maintenance in 1898 , and that the purpose of so designating it was to permit of construction and improvement work for small sums being done and charged to this accosult that would not seem to justify specific issues of Corporate Stock to accomplish the same purposes. Notwithstanding the account was given this peculiar title, being intended to provide for and allow the expenditures of small sums for park construction and improvement, as just stated, the following sums have been expended during 1906 and 1907 , in addition to those previously enumerated, for departmental labor and hired teams, and charged to Corporate Stock appropriation accounts:

Labor Cost Charged to Corporate Stock Accounts.

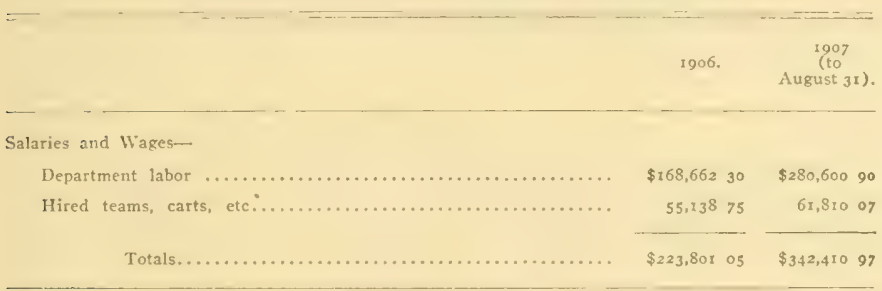

A summary of all the payments made for department labor and hired teams, horses and carts, etc., from all accounts made available for the uses of the department is here given so as to make complete the analysis of the labor cost.

\section{Summary of Payments for Labor Charged to: All Funds.}

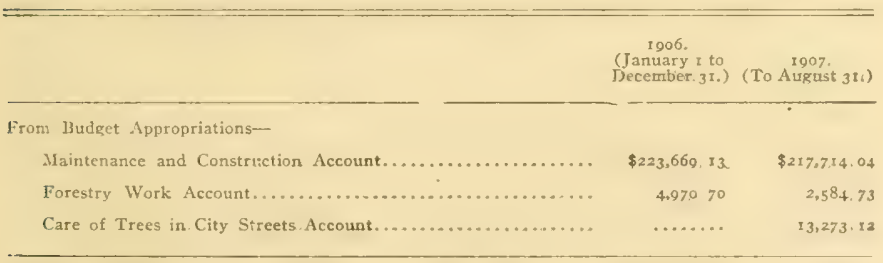




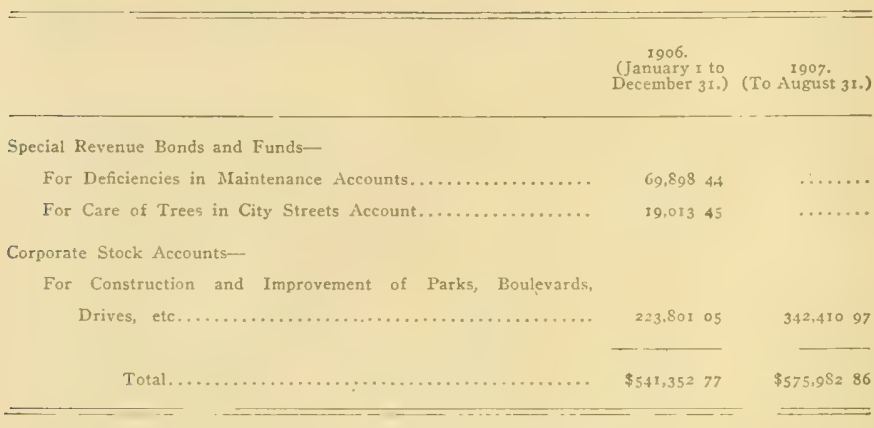

Leaving out of the calculations for both years, the payroll expenditures on account of Care of Trees in City Streets, that account being hereinafter senarately discussed, the average monthly payments for labor from maintenance accounts provided in the Budget and by Special Revente Bond issues and Corporate Stock appropriations for construction and improvements have been as follows:

\begin{tabular}{|c|c|c|}
\hline & \multicolumn{2}{|c|}{ Average Monthly Payroll } \\
\hline & 1906. & 1907. \\
\hline From Budget and Special Revenue Bond Funds............... & $\$ 24,8,800$ & $\$ 18,358$ oo \\
\hline From Corporate Stock Appropriations ........................ & 18,650 on & 28,53400 \\
\hline Average monthly payroll, all funds (approximate) .......... & $\$ 43.52800$ & $\$ 46,89200$ \\
\hline
\end{tabular}

The certifications made on the payrolls transmitted to the Department of Finance for audit and payment, are said to be based upon "time sheet" returns made by the several foremen having in charge the various gangs of workmen, it being required that the character of the service performed or description of the job be indicated on the foremen's "time sheets." Your Examiner was also informed by the Commissioner that it is the rule in the Department to assign continuously certain particular foremen to maintenance work and other certain foremen to construction and improvements. In this manner, it is claimed, the correctness is assured of the certifications on the payrolls by which are determined the charges to be made to Budget maintenance appropriations or Corporate Stock accounts. There has not, however, been sufficient time at the disposal of your Examiner to enable him to make a special examination into this matter. The statement is made by the officials of the Department that the disbursements for labor charged to Corporate Stock accounts of \$223,- 
801.05 in 1906 and $\$ 342,410.97$ during the first eight months of 1907 were proper charges, and also that it has been found more economical and more satisfactory to employ department labor in making roads and in other park construction and improvement work than to let it out to private contractors. In this connection it is hereby respectfully suggested that a special examination be made to determine the amount and character of the construction and improvement work accomplished by the Department since January $\mathrm{I}$, I906, for which charges have been made against Corporate Stock appropriations authorized for improvements.

It is recommended that the allowance for 1008 for salaries and wages be $\$ 205.000$, and for hired teams, horses and carts $\$ 30,000$.

Accounts Nos. 9-B and Io-B.

Equipment, Repairs and Renewal, Supplies and Consumable Supplies.

The disbursements for supplies made from Budget appropriation accounts during I906, as shown by the books of the Department, amounted to $\$ 29,874.72$. Of this amount about $\$ 14,000$ was for consumable supplies and $\$ 15, \$ 7+72$ for equipment repairs and renewal supplies.

It is recommended that the allowances for 1908 be as follows:

Equipment, Repairs and Renewal Supplies.................... \$18,000 00

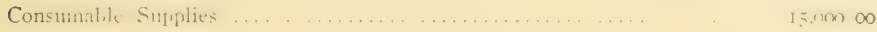

\section{Care of Trees in City Streets.}

Accounts Nos. II-B and 12-B-Salaries and Wages and Supplies.

The Budget allowance for 1907 is $\$ 20,000$, a similar amount having been provided by the issue of Special Revenue Bonds in June, Igo6. The fund for 1906 was disbursed as follows:

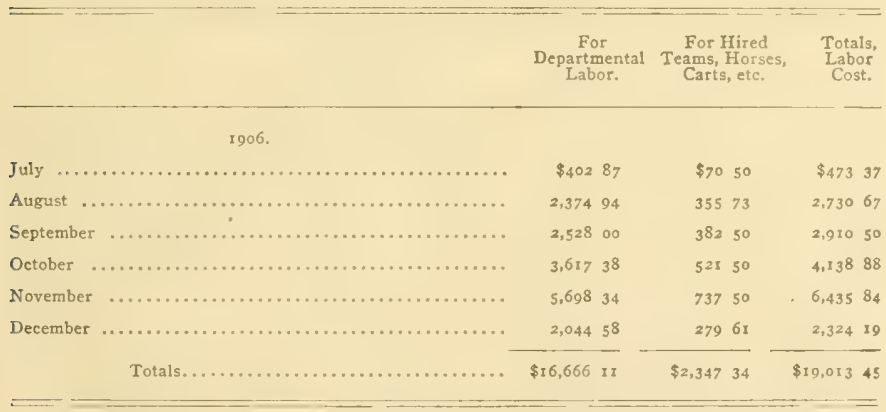

Supplies used in connection with the work of caring for street trees during 1906 cost $\$ 943.80$. 
An appropriation of $\$ 20,000$ was included in the Budget for 190\%. The disbursements from this account to August 3 i have been as follows:

\begin{tabular}{|c|c|c|c|c|}
\hline & ' & $\begin{array}{c}\text { For } \\
\text { Departmental } \\
\text { Labor. }\end{array}$ & $\begin{array}{l}\text { For Hired } \\
\text { Teams, Horses, } \\
\text { Carts, etc. }\end{array}$ & $\begin{array}{l}\text { Totals, } \\
\text { Labor } \\
\text { Cost. }\end{array}$ \\
\hline & 1907. & & & \\
\hline January . & 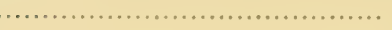 & $\$ 1,258 \quad 56$ & $\$ 19512$ & $\$ 1,45368$ \\
\hline February & 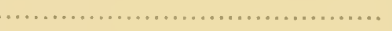 & 88373 & $118 \quad 12$ & $\mathbf{x}, 00185$ \\
\hline March ... & $\cdots \cdot$ & 685 oo & 91.00 & 77600 \\
\hline April .... & $\cdots$ & $555 \quad 25$ & Bo 50 & 63575 \\
\hline May ... & $\ldots$ & $x, 15800$ & $200 \quad 37$ & $x, 358 \quad 37$ \\
\hline June .... & $\cdots$ & $x, 58250$ & 22925 & $x, 8: 175$ \\
\hline July ... & & $2,222 \quad 72$ & 25875 & $2,481 \quad 47$ \\
\hline August: . . & ( $\ldots \ldots \ldots$ & 3,31175 & 44250 & 3.75425 \\
\hline & 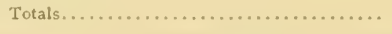 & $\$ 11,65751$ & $\$ \mathrm{x}, 6156 \mathrm{r}$ & $\$ 23,273 \quad 12$ \\
\hline
\end{tabular}

Your Examiner was informed that during the past year the Head Gardener of the Department, under the direction of the Commissioner, plotted out the streets of the borough into sections, and has made an estimate of the number of trees which are now under the law placed in the jurisdiction of the Department of Parks. It is estimated that there are $\mathrm{I} \_0,000$ such trees.

The estimate for $190 \$$ is $\$ 40,092.50$, the estimate for labor being $\$ 38,092.50$ and $\$ 2,000$ being for supplies:

It is recommended that an allowance of $\$ 38,000$ be made for salaries and wages and $\$ 2,000$ for supplies.

\section{III:-SUNDRY APPROPRIATIONS.}

Account No. ${ }_{3}-\mathrm{B}-$ Music. .

The appropriation for music in the 1907 Budget was $\$ 9,000$. The amount asked for 1908 is $\$ 15,600$. In 1906 the amount expended was $\$ 9,000$. This provided for ninety concerts, or ten each. in. nine different parks, the bands consisting of a leader, one soloist and sixteen musicians each. In I900 and I90I, thè Commissioner says, the annual appropriation for music was $\$ 12,400$. This allowed for each park, twentytwo musicians, at $\$ 5$; one soloist, at $\$ \mathrm{ro}$, and one leader, at $\$ \mathrm{ro}$, a total of $\$ 130$ for each concert. The appropriations in these years permitted a series of twelve concerts in eight parks: It is the desire of the Commissioner that provision be made for 1908 for ten concerts each in twelve parks, with twenty-two pieces, one soloist and one leader, at a cost of $\$ 130$ per concert.

It is recommended that an allowance of $\$ 12,000$ be made for 1908 . 


\section{IV.-MAINTENANCE OF INSTITUTIONS.}

\section{Botanical Gardens.}

The Budget appropriation for the maintenance of the New York Botanical Garden during 1907 was $\$ 75,000$, or $\$ 5,000$ less than was provided in the Budget of 1906 . The estimated amount required in 1908 is $\$ 104,630$. The expenditures in 1906 were $\$ 80,000$, and for 1907 it is estimated the cost of maintenance will reach approximately $\$ 88,000$. In this event the difference between this amount and $\$ 75,000$, provided by the City in the Tax Budget, will have to be made up out of the funds of the Botanical Garden Corporation. It is discretionary with the budget-making authorities of the City as to what sums may be provided for the maintenance of the New York Botanical Garden. (See sections 613 and 625 of the Greater New York Charter.) The Budget allowances for maintenance since 5000 have been as follows:

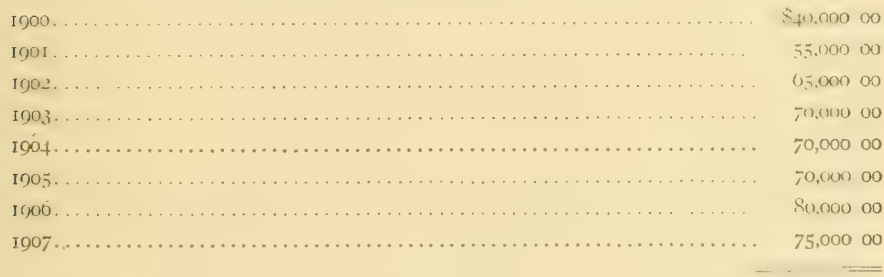

The New York Botanical Garden was incorporated by the enactment of chapter 285 of the Laws of 1891 , which enactment was amended by chapter 103 of the Laws of 1894 . The management is intrusted to eleven directors, of whom the Mayor of The City of New York and the President of the Board of Commissioners of the Department of Public Parks shall be two. On July 3I, I895, the directors accepted an appropriation of two hundred and fifty acres in the Bronx Park, authorized by the Commissioners of Parks for the establishment of a butanical garden, as provided in the acts of incorporation previously referred to. After some time spent in perfecting an organization, development plans were prepared and approved for parking, grading, water supply and draining the land, as weil as for the construction of certain roads, drives, paths, conservatories, hothouses, bridges, muscum buildings, etc.

Inasmuch as the yearly appropriations for maintenance are in a large sense controlled by the areas of park lands and buildings to be cared for and kept in repair, inquiry was made by your Examiner as to what stage the development scheme had reached at this time. The Director of the Garden says that the work of parking, road and path building has continued steadily since 1895 , much of it being done by the labor force of the corporation, there being large quantities of stone on the land available for roudmaking. The work of parking has been completed in about three-fourths of the area; seven-eighths of the roadmaking and three-fifths of the pathbuilding has 
been finished. There is a large boiler house and low glass-covered hothouse now being built, which, when finished, will probably be all that may be required in the way of buildings. It is therefore the conclusion of the Director that within a year or two at the most the Gardens will have been completed, when the cost of yearly maintenance may be determined and fixed at a specific amount, which shall relatively be unchanging from year to year.

\section{Account No. I4-B-Salaries and Wages.}

The amount asked for Salaries and Wages is $\$ 83.830$, the yearly cost for 1007 , as indicated by the payroll on July I last, being $\$ 70,860$. The proposed increase of $\$ 12,970$ is to provide for small advances in the salaries and wages of certain of the present force, amounting to $\$ \mathrm{r}, 4$ To (the highest amount in any one case being $\$ 180$ ), and $\$$ II,560 for the establishment of new positions. Examination has shown that the salaries and wages paid to the employees of the corporation are in every case as low, if not lower than those paid to employees of other City departments where the duties are similar. There will be no advances allowed during the current year owing to the shortage of the appropriation account, and there were only a few very small ones in 1906 .

The proposed new positions are to provide for the maintenance of the second range of conservatories and plantations now under development and the care of the new greenhouses and boiler house, both of which are now being built. As the new boiler house and greenhouses will probably not be completed until April or May and but little work can be done on the new parking, plantations and lawns until the spring season, $\$ 8,000$ will be sufficient to provide for all the new help that will be required next year. This, with the $\$ 1$.fio for small advances in wages and salaries, should be

allowed. It is therefore recommended that the allowance for salaries and wages for 1008 be $\$ 80,270$.

\section{Account No. I5-B-Repairs and Renewals (Buildings).}

The amount specified as being required during 1908 for general expenses, including telephone and supplics and repairs, is $\$ 20,800$. or $\$ 3,670.01$ more than was expended for similar purposes in rgo6.

The items specified in the estimate for 1908 which may be classified under the heading Repairs and Renewals (Buildings) amount to $\$ 3,000$, and it would seem a reasonable estimate, judging from the number and character of the buildings to be maintained during 1908 .

An allowance of $\$ 3.000$ is recommended.

\section{Account No. 16-B-Supplies.}

The items specified in the 1908 estimate aggregate $\$ 17,100$. Of this amount $\$ 13,000$ is for coal, as compared witl expenditures of $\$ 10,641.64$ in 1906 . The coal estimate 
may be reduced $\$ 1,000$, as the new grecnlouses, the heating of which during the coming winter and spring was contemplated when the estimate was prepared, will not require coal until October. Some of the other items may also be reducul proportionately for $t^{\text {t }}$ : same reason.

It is recommended that an allowance of $\$ \mathrm{r}, 4,000$ be made.

\section{Account No. 17-B-Incidental Expenses.}

An allowance of $\$ 600$ is recommended for incidental expenses, to cover the cost of office supplies, lantern slides and other lecture supplies and casualty insurance on the boilers and elevators.

Account No, 18-B-Telephone, Rental of.

The cost of telephone service for 1908 is placed at \$Ico and an inpropriation of this amount is recommended.

\section{Zoological Gardens.}

The estimate of the New York Zoological Gardens for 1908 aggregates \$168,200, as compared with $\$ 141,558.75$ appropriated for 1907 . The disbursements for maintenance during the year I906, as shown by the annual report of the treasurer of the New York Zoological Gardens, were $\$ 141.965$, of which amount \$93.831.87 were expended for Salaries and Wages, $\$ 1 \mathrm{r}, 279.57$ for Repairs and Renervals of Buildings and Installations, $\$ 844.22$ for telephone rental and the balance of $\$ 39,009.3+$ for supplies and incidental expenses.

The Director of the Gardens, in a communication dated July 6, 1907, transmitting the estimate for 1908 to the Commissioner of Parks, Borough of The Bronx, said:

"I respectilly call your attention to the fact that a large increase over 1907 is imperatively necessary; first, because the appropriation for 1907 is entirely inadequate, and will leave a deficiency at the end of the year to be met by private individuals; and, secondly, because of the increase in the buildings and animals to be cared for in 1908. Last year we asked for the increase that was needed for this year, but instead of an increase the amount allowed for 1906 was reduced by $\$ 3,400$. * * *

"We have to maintain Io very large animal buildings, to animal buildings of smaller size, ro large groups of outdoor dens, aviaries and corrals, 6 public comfort buildings, 8 entrances, $73 / 4$ miles of walks and roads, $10 \frac{1}{2}$ miles of fences, and care for a park of 264 acres. The living animals to be cared for number over 3,800 , and there came to see them in $1906 \mathrm{I}, 321,917$ visitors.

"We respectiully insist that the amount of maintenance now allowed by the City is entirely out of proportion with the total cost of supplies and fuel to be purchased and work to be done. A small increase over 1907 will not answer, because the amount for 1907 is at least $\$ 10,000$ below what it should be. 
"I beg to assure you that in asking for $\$ 168,200$ for 1908 we ask only for what we actually need for legitimate and imperative demands, based on a long-standing system of close economy in expenditures."

The estimate of $\$ 168,200$, as furnished by the Director, is divided into five items, as follows:

Salaries and Labor, General Administration.................... \$19,532 oo Salaries, Labor in Maintenance and Repairs of Buildings, and Care of

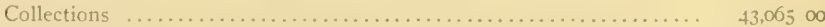

Salaries and Labor in Mlaintenance and Care of Grounds............ 35,410 oo

General Expenses, including Materials, Food, Supplics and Services.... 59,6r3 oo

Additional maintenance funds now required for new buildings and in-

stallations, and for the care of roo acres of park lands east of the

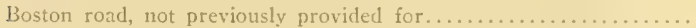

10,55000

\section{Account No. Ig-B-Salaries and Wages.}

The payrolls for June, 1907, contained the names of 123 employees at rates of compensation aggregating $\$ 97,977$ per annum. The estimate for 1908 is for $\$ 105,447$, or an increase of $\$ 7,470$, it being proposed to add eleven persons to the force.

The orly salary increase proposed ove- those now being paid is $\$ 60$ for one Gatekeeper, whose present rate of comyensation : $\$ 660$ a year. Provision is asked for the establishment of new positions to care for and maintain a new public comfort station at the subway entrance now nearing completion, a new concourse entrance to be finished early in I908; and for the care of the park grounds east of the Boston road, for which, it is stated, insufficient appropriations have been allowed in the past, the result being thiat these grounds liave never been fully developed. The proposed new positions and the compensation to be paid in each case are as follows:

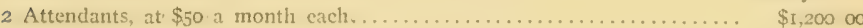

3 Attendants, at $\$ 60$ a month each........................... 2,160 oo

2. Helpers, at $\$ 20$ a month each......................... $\$ 80$ oo

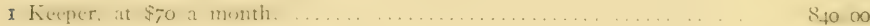

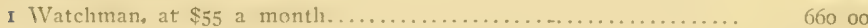

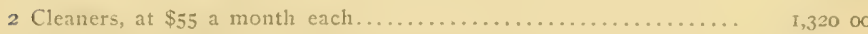

I Horse, Cart and Driver, 300 days, at $\$ 2.50$ per day................ 750 oo

Tital...................................... \$7,410 oo

The total net increase in salaries and wages as proposed for Igo 8 , over the yearly cost as indicated by the payrolls for June, I907, is therefore $\$ 7,470$. Of this amount it would appear that not less than $\$ 6,000$ will be actually required on account of the new responsibilities of the management for maintenance.

An allowance of $\$ 103,977$ for Salaries and Wages is recommended. 


\section{Account No. 20-B-Repairs and Renewal Supplies (Buildings).}

Under the head of general experses, disbursements during 1906, amounting to $\$ 51,133.13$, are scheduled and enumerated in the Igo\$ estimate furnished by the Director. The expenditures for items that may properly be classified as Repairs and Renewal, Supplies (Buildings), amounted to $\$ \mathrm{II}, 279.57$. The amount asked for 1908 is $\$ \mathrm{II}, 6 \mathrm{I} 3$.

It is recommended that an allowance of $\$ 11,500$ be made for igos.

\section{Account No. 2I-B-Supplies.}

The most important items under this head are food for the animals and fucl. In 1906 the total expenditures for consumable supplies, such as it is proposed to provide for in this account, were $\$ 37,272.17$. Of this amount $\$ 26,269$. I 8 were for foot for the animals and $\$ 4,904.66$ for fuel. It is estimated that $\$ \$ 4,034$ will be required for supplies during 1908. Of this amount $\$ 31,116$ is specified as being needed for food and $\$ 6,052$ for fuel.

Examination of the schedules submitted with the estimate shows that certain of the amounts specified as required during I908 may be considerably reduced, as it would seem that the disbursements made in 1906 for these purposes represent purchases for original equipment, the 1908 estimates in each instance being based upon the expenditures during 1906. The increased amount asked for in Igos over the boo disbursements is $\$ 6,761.83$.

It is recommended that an allowance of $\$ 40,750$ be made in the Budget for rgas.

\section{Account No. 22-B-Incidental Expenses.}

This account is intended to provide for such expenditures as office supplies and printing, postage, telegraph and express charges, office furniture and fixtures, medical attendance for the animals, signs and labels, etc. In Igor the expenditures for these purposes were $\$ 2,729.17$. For I908 the Director asks that $\$ 3.037$ be allowed.

It would appear from an examination of the several items specified that $\$ 2,500$ would be sufficient for 1908 .

\section{Account No. 23-B-Telephone, Rental of.}

Telephone service cost $\$ 844.92$ in 1906 . For $1908 \$ 929$ is requested. An allowance of $\$$ soo is recommended.

\section{COMPARATIVE STATEMENT OF ALL ACCOUNTS.}

Attached to this report will be found a tabulation showing the Budget appropriations for 1907 , the estimated amounts required for 1908 , with the recommended allowances as contained herein. 


\section{LIST OF SCHEDULES OF PAYROLL PAYMENTS, I906-I907.}

Appended hereto will also be found statements showing the payments made on account of payrolls by the Department of Parks, Borough of The Bronx, from January I, 1906, to August 3I, 1907, marked as specified below:

Payroll Schedule No. I-B, showing payroll payments for Department employees during I906, from Budget account, Maintenance and Construction.

Payroll Schedule No. 2-B, showing payroll payments for Department employees during 1906, from Budget account, Forestry Work.

Payroll Schedule No. 3-B, showing payroll payments for Department employees during 1906, from Special Revenue Bond Funds.

Payroll Schedule No. 4-B, showing payroll payments for Department employees during 1906, from Corporate Stock Appropriations.

Payroll Schedule No. 5-B, Summary, showing payroll payments for Department employees during 1906 , from all accounts.

Payroll Schedule No. 6-B, showing payroll payments for Department employees during 1907 (to August 3r), from Budget account, Maintenance and Construction.

Payroll Schedule No. 7-B, showing payroll payments for Department employees during 1907 (to August 31), from Budget account, Forestry Work.

Payroll Schedule No. 8-B, showing payroll payments for Department employees during 1907 (to August 3I), from Budget account, Care of Trees in City Streets.

Payroll Schedule No. 9-B, showing payroll payments for Department employees during 1907 (to August 3I), from Corporate Stock appropriations.

Payroll Schedule No. IO-B, Summary, showing payroll payments for Department employees during 1907 (to August 31 ), from all accounts.

Payroll Schedule No. II-B, showing payroll payments during 1906 for hired teams, horses and carts, from Budget account, Maintenance and Construction.

Payroll Schedule No. I2-B, showing payroll payments during 1906 for hired teams, horses and carts, from Budget account, Forestry Work.

Payroll Schedule No. 13-B, showing payroll payments during Igo6 for hired teams, horses and carts, from Special Revenue Bond Funds for Deficiencies.

Payroll Schedule No. I4-B, showing payroll payments during 1906 for hired teams, horses and carts, from Special Revenue Bond Funds for Care of Trees in City Streets.

Payroll Schedule No. 15-B, showing payroll payments during 1906 for hired teams, horses and carts, from Corporate Stock appropriations.

Payroll Schedule No. 16-B, Summary of Schedules Nos. II-B, I2-B, 13-B, I4-B and I5-B. 
Payroll Schedule No. I7-B, showing payroll payments, Jantary $\mathrm{r}$ to August 3r, 1907, hired teams, horses and carts, from Budget account, Maintenance and Construction.

Payroll Schedule No. I8-B, showing payroll payments, January I to August 3I, 1907, hired teams, horses and carts, from Budget account, Forestry Work.

Payroll Schedule No. I9-B, showing payroll payments, January I to August 3I, 1907, hired teams, horses and carts, from Budget account, Care of Trees on City Streets.

Payroll Schedule No. 20-B, showing payroll payments, January I to August 3I, 1907, hired teams, horses and carts, from Corporate Stock appropriations.

Payroll Schedule No. 2I-B, Summary of Schedules Nos. I7-B, I8-B, I9-B and 20-B.

Respectfully,

CHARLES S. HERVEY,

Supervising Statistician and Examiner. 


\section{Administration.}

Salaries and Wages:

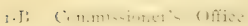

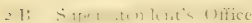

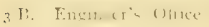

$\therefore$ II Xing it .

5.1: Cintinzture

o.1: Tileflane. Rental of

II. Maintenance of Parks, Boulevards, Drives, Stonework and Street Trees.

Parks and Boulevards:

-.I:. Salaries and IVages.

8.1: Hired Teams and Carts, Road Macinines and Rollers.

1. 1:. Equipment, Repairs and Renewal Supplies....

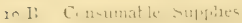

Care of Trees in City Streets:

:r-R. Stark- anil Wages

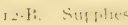

III. Sundry Appropriations.

13-13. $1111 \div$

* Surveys, Maps and Plans.

Totat

IV. Maintenance of Institutions.

New York Botanical Garden:

1.5. Fi. Saltric and Wages.

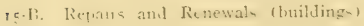

16. B. Silvplies"

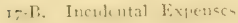

18.B. Telegdune, licntal of . 


\section{BOROUGH OF THE BRONX.}

I907, the Estimate and Recommended Allowances for Igo8.

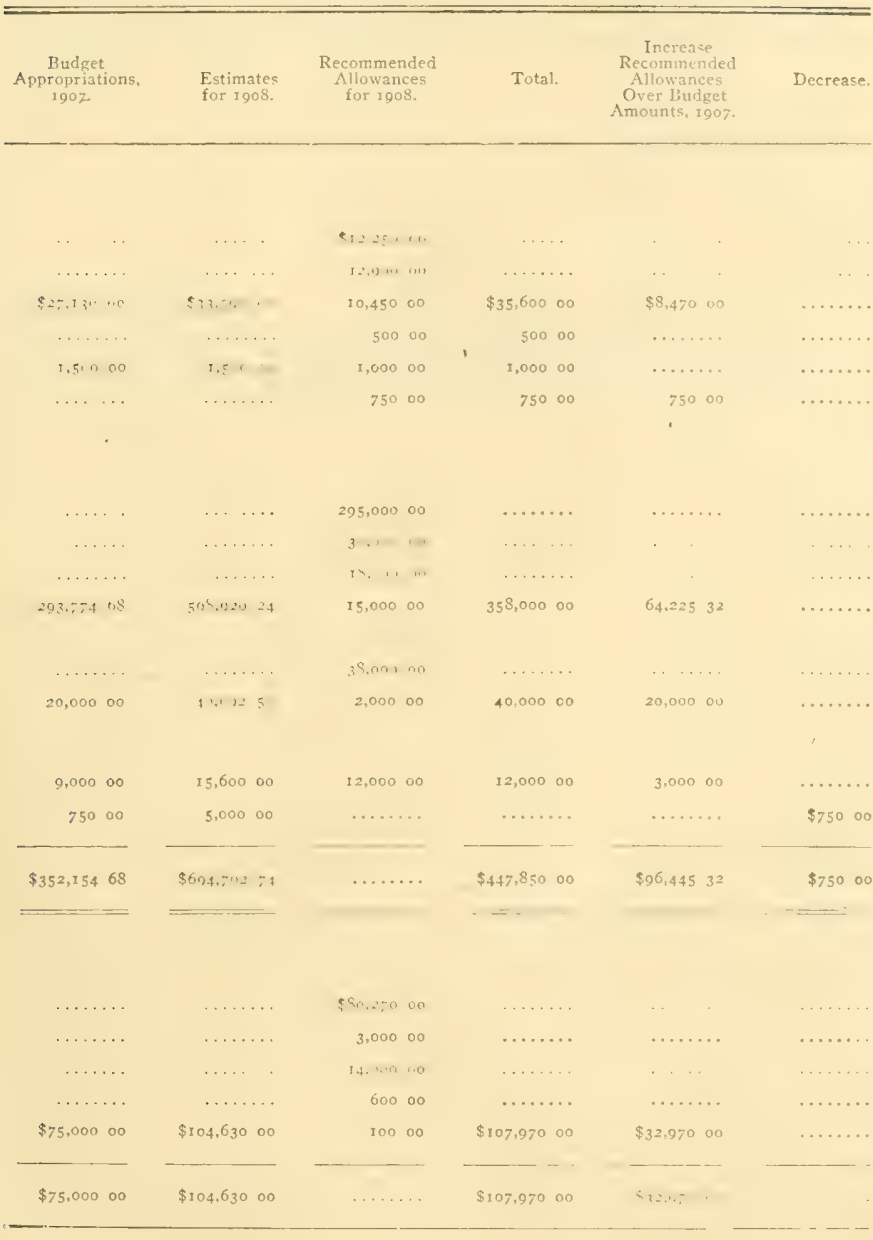


New York Zoological Garden:

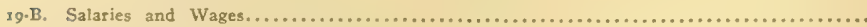

20-B, Repairs and Renewals (buildings)

ar.B. Supplies

20-B. Incidental Expenses

23-B. Telephone, Rental of....

Total

"This Appropriation Account has been eliminated in the revised Budget form.

Note-Increase recommended allowances over 1907 Budget allowances, \$95,695.32. Deducting $\$ 20,000$ is in the Account for the Care of Trees in City Streets. 
35

\begin{tabular}{|c|c|c|c|c|c|}
\hline $\begin{array}{c}\text { Budget } \\
\text { Appropriations, } \\
\text { I907. }\end{array}$ & $\begin{array}{l}\text { Estimates } \\
\text { for } 1908 .\end{array}$ & $\begin{array}{l}\text { Recommended } \\
\text { Allowances } \\
\text { for } 1908 .\end{array}$ & Total. & $\begin{array}{l}\text { Increase } \\
\text { Recommended } \\
\text { Allowances } \\
\text { Over Budget } \\
\text { Amounts, r907. }\end{array}$ & Decrease. \\
\hline \multicolumn{6}{|l|}{, } \\
\hline ........ & ........ & $\$ 103.97700$ & ........ & ......... & . \\
\hline ........ & $\ldots ; \ldots \ldots$ & $I I, 50000$ & ........ & ........ & \\
\hline ........ & ....... & 40,75000 & $\cdots \ldots \ldots$ & ........ & \\
\hline ........ & ........ & 2,50000 & ........ & ........ & $\ldots$ \\
\hline$\$ 141,55^{8} 75$ & $\$ 168,20000$ & 90000 & $\$ 159,62700$ & $\$ 28,068=5$ & ........ \\
\hline$\$ 141,558 \quad 75$ & $\$ 168,20000$ & $\ldots \ldots$ & - $\$ 159,62700$ & $\$ 18,068 \quad 25$ & ....... \\
\hline
\end{tabular}

Special Revenue Bonds amounting to $\$ 46,000$, leaves a net increase of $\$ 49,695.32$, of which amount 
Recapitulation.

\begin{tabular}{|c|c|c|c|c|}
\hline & $\begin{array}{l}1907 \text { Budget } \\
\text { Appropriations. }\end{array}$ & $\begin{array}{c}\text { Departmental } \\
\text { Estimates } \\
\text { for } 1908 .\end{array}$ & $\begin{array}{l}\text { Recommended } \\
\text { Allowances } \\
\text { for } 1908 .\end{array}$ & $\begin{array}{c}\text { Increase } \\
\text { Recommended } \\
\text { Allowances } \\
\text { for } 1908 \\
\text { Over } 1907 \\
\text { Budget } \\
\text { Appropriations. }\end{array}$ \\
\hline Department of Parks.......... & $\$ 352,15468$ & $\$ 694,70274$ & $\$ 447,850$ oo & $\$ 95,695 \quad 32$ \\
\hline New York Botanica! Gardens... & 75,00000 & 104,630 o0 & 107,97000 & 32,97000 \\
\hline New York Zoological Gardens.... & $147,558 \quad 75$ & 168,20000 & 159,62700 & $18,068 \quad 25$ \\
\hline Total............ & $\$ 568,71343$ & $\$ 967,53274$ & $\$ 715.44700$ & $\$ 146,73357$ \\
\hline
\end{tabular}

Payroll Schedule No. iB.

DEPARTMENT OF PARKS, BOROUGH OF THE BRONX.

Statemcrit shoacing payments on accoint of payrolls for Superintendent, Engincers, Foremen, Gardeners, Laborers, etc., during 1906, from Budget Appropriation Account, Maintenance and Construction:

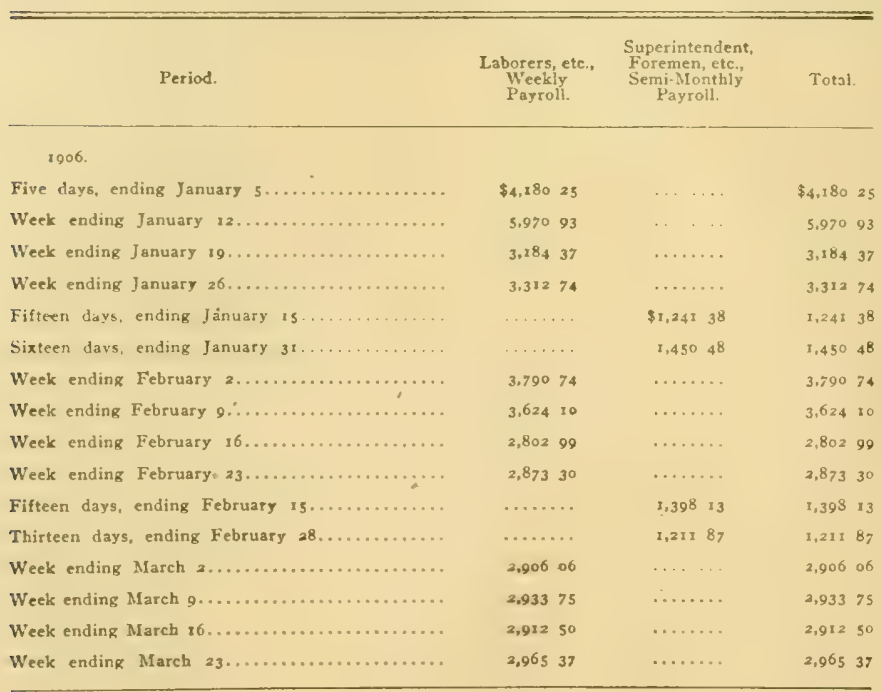




\begin{tabular}{|c|c|c|c|}
\hline Period. & $\begin{array}{c}\text { Laborers, etc., } \\
\text { Weekly } \\
\text { Payroll. }\end{array}$ & $\begin{array}{c}\text { Superintendent, } \\
\text { Foremen, efc.; } \\
\text { Semi-Monthly } \\
\text { Payroll. }\end{array}$ & Total. \\
\hline 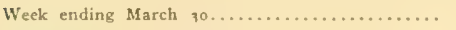 & 3.02924 & $\ldots \ldots \ldots$ & $3,029 \quad 24$ \\
\hline Fifteen days, ending March $85 \ldots \ldots \ldots \ldots \ldots$ & $\ldots \ldots \ldots$ & 1,26276 & $1,26 \times 76$ \\
\hline Sixteen days, ending March $31 \ldots \ldots \ldots \ldots \ldots$ & $\ldots \ldots \ldots$ & 1,46668 & $x, 466 \quad 6 \mathrm{r}$ \\
\hline 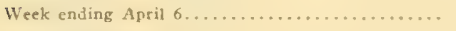 & 3,06982 & $\ldots \ldots \ldots$ & 3.06982 \\
\hline 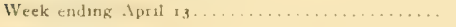 & 4,69809 & $\ldots \ldots \ldots$ & 4,69809 \\
\hline Week ending April $20 \ldots \ldots \ldots \ldots \ldots \ldots \ldots \ldots$ & 5,55350 & $\ldots \ldots \ldots$ & $5,553 \quad 50$ \\
\hline Week ending April $27 \ldots \ldots \ldots \ldots \ldots \ldots \ldots . . . . . . .$. & 5,12759 & $\ldots \ldots \ldots$ & $5, \mathbf{3} 2759$ \\
\hline Fifteen days, ending April $15 \ldots \ldots \ldots \ldots \ldots \ldots$ & ...... & 1.40500 & 1,405 o0 \\
\hline Fifteen days, ending April $30 \ldots \ldots \ldots \ldots \ldots \ldots$ & $\ldots \ldots \ldots$ & $x, 39250$ & 1,39250 \\
\hline Week ending May $4 \ldots \ldots \ldots \ldots \ldots \ldots \ldots \ldots \ldots \ldots \ldots \ldots \ldots \ldots$ & 6,10368 & 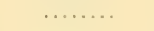 & 6,10368 \\
\hline 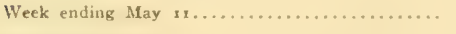 & $5,9 \times 423$ & $\cdots \cdots \cdots$ & $5,914 \quad 23$ \\
\hline Week entung May $18 \ldots \ldots$. . . & 6,09168 & .. $\ldots$ & $6,0,9108$ \\
\hline Week enting May $25 \ldots \ldots \ldots \ldots$. & 5.84900 & $\ldots \ldots$ & 5.84900 \\
\hline Fifteen days, ending May ${ }^{5} 5 \ldots \ldots \ldots \ldots \ldots$ & $\ldots \ldots \ldots$ & $\mathrm{x}, 49257$ & 1,49257 \\
\hline 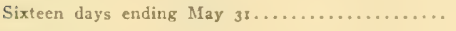 & $\ldots \ldots \ldots$ & 1,59243 & 1,59243 \\
\hline Week ending June $r \ldots \ldots \ldots \ldots \ldots \ldots \ldots \ldots$ & 5,25135 & $\ldots \ldots \ldots$ & 5,25135 \\
\hline Week ending June $8 \ldots \ldots \ldots \ldots \ldots \ldots \ldots \ldots$ & 5.92250 & $\cdots \cdots \cdots$ & 5.92350 \\
\hline Week ending June $15 . \ldots \ldots$. & 5.94749 & . & $5.9+749$ \\
\hline Week ending June $22 \ldots \ldots \ldots \ldots \ldots \ldots \ldots \ldots$ & 5.35764 & 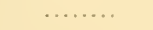 & 5,35764 \\
\hline Week ending June $29 \ldots \ldots \ldots \ldots \ldots \ldots \ldots \ldots$ & $5,816 \quad 17$ & $\cdots \cdots \cdots$ & $5,8 \times 6 \times 7$ \\
\hline Fifteen days, ending June $15 \ldots \ldots \ldots \ldots \ldots \ldots$ & $\cdots \cdots \cdots$ & 1,39250 & 1,39250 \\
\hline Fifteen days, ending June $30 \ldots \ldots \ldots \ldots \ldots \ldots$ & $\cdots \cdots \cdots$ & 1,39250 & $x, 39250$ \\
\hline 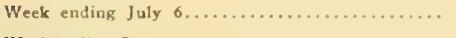 & 2,92700 & $\cdots \cdots \cdots$ & 2,92700 \\
\hline 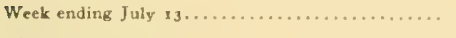 & 3,32625 & $\cdots \cdots \cdots$ & 3.32625 \\
\hline Week ending July $20 \ldots \ldots \ldots \ldots \ldots \ldots \ldots \ldots$ & 3.37254 & ........ & 3.37254 \\
\hline Week ending July $27 \ldots \ldots \ldots \ldots \ldots \ldots \ldots \ldots \ldots$ & $2,885,73$ & $\cdots \cdots \cdots$ & 2,88532 \\
\hline Fifteen days, ending July $85 \ldots \ldots \ldots \ldots \ldots$ & $\cdots \cdots \cdots$ & 1,02328 & 1,02328 \\
\hline Sixteen days, ending July s $\ldots \ldots \ldots \ldots \ldots \ldots$ & $\cdots \cdots \cdots$ & 1,10204 & 1,10204 \\
\hline Week ending August $3 \ldots \ldots \ldots \ldots \ldots \ldots \ldots \ldots$ & 3,89899 & $\ldots \ldots \cdots$ & 2,89899 \\
\hline Week ending August $t 0, \ldots \ldots \ldots \ldots \ldots \ldots$ & $2,720 \quad 50$ & $\cdots \cdots \cdots$ & 2,720 so \\
\hline Week ending August $27 \ldots \ldots \ldots \ldots \ldots \ldots \ldots$ & $2,97+81$ & $\ldots \ldots \ldots$ & $2,97+82$ \\
\hline Week ending August $24, \ldots \ldots \ldots \ldots \ldots \ldots . . . . . .$. & 2,87272 & $\cdots \cdots \cdots$ & 2,87272 \\
\hline Week ending August $3 x \ldots \ldots \ldots \ldots \ldots \ldots \ldots$ & 2,83150 & $\ldots \ldots \ldots$ & $2,83 \mathrm{r}$ so \\
\hline Fifteen days, ending August $15 \ldots \ldots \ldots \ldots \ldots$ & $\ldots \ldots \ldots$ & $x, 01296$ & 2,01296 \\
\hline Sixteen days, ending August $3 x, \ldots \ldots \ldots \ldots \ldots$ & $\cdots \cdots+$ & $1, x \geq 010$ & 1,120 to \\
\hline Week ending September $7 \ldots \ldots \ldots \ldots \ldots \ldots \ldots$ & 2,94350 & $\ldots \ldots \ldots$ & 2,94350 \\
\hline
\end{tabular}




\begin{tabular}{|c|c|c|c|}
\hline Period. & $\begin{array}{c}\text { Laborers, etc., } \\
\text { Weekly } \\
\text { Payroll. }\end{array}$ & $\begin{array}{c}\text { Superintendent, } \\
\text { Foremen, etc., } \\
\text { Semi-Mionthly } \\
\text { Payroll. }\end{array}$ & Total. \\
\hline Week ending September $r 4 \ldots \ldots \ldots \ldots \ldots \ldots . . . . .$. & 2,74400 & $\ldots \ldots \ldots$ & 2,74400 \\
\hline 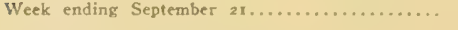 & 2,74975 & $\ldots \ldots \ldots$ & 2,74975 \\
\hline Week ending September $28 \ldots \ldots \ldots \ldots \ldots \ldots$ & $2,682 \quad 59$ & ......... & 2,68259 \\
\hline Fifteen days, ending September rs $\ldots \ldots \ldots \ldots \ldots$ & $\cdots \cdots \cdots$ & 1,05083 & 1,05083 \\
\hline Fifteen days, ending September $30 . \ldots \ldots \ldots \ldots \ldots$. & $\ldots \ldots \ldots$ & 1,01012 & $x, 01012$ \\
\hline Week ending October $5 \ldots \ldots \ldots \ldots \ldots \ldots \ldots \ldots \ldots$ & $2,495 \quad 63$ & $\cdots \cdots \cdots$ & $2,495 \quad 63$ \\
\hline Week ending October $12 \ldots \ldots \ldots \ldots \ldots \ldots \ldots \ldots$ & 2,34200 & $\cdots \cdots \cdots$ & 2,34200 \\
\hline Week ending October $19 \ldots \ldots \ldots \ldots \ldots \ldots \ldots$ & 2,33900 & $\cdots \cdots$ & 2,33900 \\
\hline Week ending October $26 \ldots \ldots \ldots \ldots \ldots \ldots \ldots$ & 2,34050 & $\cdots \cdots \cdots$ & 2,34050 \\
\hline Fifteen days, ending October $15 \ldots \ldots \ldots \ldots \ldots$ & ….... & $8,057 \quad 14$ & $1,057 \quad 14$ \\
\hline Sixteen days ending October $31 \ldots \ldots \ldots \ldots \ldots \ldots$ & $\cdots \cdots \cdots$ & 3,01172 & $2,012 \quad 72$ \\
\hline Week ending November $2, \ldots \ldots \ldots \ldots \ldots \ldots$. & $2,347 \quad 52$ & $\cdots \cdots+$ & 2,34752 \\
\hline Week endings November $9 \ldots \ldots \ldots \ldots \ldots \ldots . . . .$. & $2,355 \mathrm{IX}$ & $\cdots \cdots \cdots$ & $2,355 \quad 13$ \\
\hline Week ending November $16 \ldots \ldots \ldots \ldots \ldots \ldots$ & 1,79298 & $\cdots \cdots \cdots$ & 1,19298 \\
\hline Fifteen days, ending November $15 \ldots \ldots \ldots \ldots$ & $\cdots \cdots \cdots$ & $1 \mathrm{x}, \mathrm{x} I 9 \quad 16$ & $1, x 19 \times 6$ \\
\hline Week ending December $2 x \ldots \ldots \ldots \ldots \ldots \ldots$ & 1,79991 & $\cdots \cdots \cdots$ & 1,79998 \\
\hline Ten days, ending December $32 \ldots \ldots \ldots \ldots \ldots$ & $5.978 \pm 6$ & $\cdots \cdots \cdots$ & 5,97816 \\
\hline Sixteen days, ending December $31 \ldots \ldots \ldots \ldots \ldots$ & $\cdots \cdots \cdots$ & 1,57145 & $1,37 \times 45$ \\
\hline Total.... & $\$ 176,38567$ & $\$ 27,793 \quad 34$ & $\$ 204,179$ o8 \\
\hline
\end{tabular}

Payroll Schedule No. $2 \mathrm{~B}$.

DEPARTMENT OF PARKS, BOROUGH OF THE BRONX.

Statement shorving payments during 1906 on account of payrolls for Superintendent, Foremen, Laborcrs, etc., from Budget Appropriation Account, Forestry Work:

\begin{tabular}{|c|c|c|c|}
\hline Period. & $\begin{array}{c}\text { Laborers, etc., } \\
\text { Weekly } \\
\text { Payroll. }\end{array}$ & $\begin{array}{c}\text { Superintendent, } \\
\text { Foremen, etc., } \\
\text { Semi-Monthly } \\
\text { Payroll. }\end{array}$ & Total. \\
\hline 1906 & & & \\
\hline Five days of week ending January $5 \ldots \ldots \ldots \ldots \ldots$ & $\$ 19350$ & $\cdots \cdots$ & $\$ 19350$ \\
\hline Week ending January $12 \ldots \ldots \ldots \ldots \ldots . . . . . .$. & 29750 & $\therefore \ldots$ & 29750 \\
\hline Week ending January $26 \ldots \ldots \ldots \ldots \ldots \ldots \ldots$ & 38400 & ...... & 18400 \\
\hline Fifteen days ending January $15 \ldots \ldots \ldots \ldots \ldots$ & $\ldots \ldots$ & $\$ 3699$ & 3699 \\
\hline Sixteen days ending $f_{\text {anuary }} 3 x \ldots \ldots \ldots \ldots \ldots$ & $\cdots \cdots$ & $387 x$ & 3878 \\
\hline Week ending February $2, \ldots \ldots \ldots \ldots \ldots \ldots$ & 81500 & $\ldots \ldots$ & 11500 \\
\hline
\end{tabular}




\begin{tabular}{|c|c|c|c|}
\hline Period. & $\begin{array}{c}\text { Laborers, etc., } \\
\text { WVeekly } \\
\text { Payroll. }\end{array}$ & $\begin{array}{c}\text { Superintendent, } \\
\text { Foremen, etc., } \\
\text { Semi-Monthly } \\
\text { Payroll. }\end{array}$ & Total. \\
\hline Week ending February $9 \ldots \ldots \ldots \ldots \ldots \ldots \ldots$ & 23374 & $\cdots \cdots$ & 23374 \\
\hline Week ending February $16 \ldots \ldots \ldots \ldots \ldots \ldots \ldots$ & 18374 & $\ldots \ldots$ & 18374 \\
\hline Week ending February $23 \ldots \ldots \ldots \ldots \ldots \ldots$ & 18673 & $\cdots \cdots$ & 18673 \\
\hline Fifteen days ending February $x 5 \ldots \ldots \ldots \ldots \ldots$ & $\cdots \cdots$ & $40 \times 7$ & 4017 \\
\hline Thirteen days ending February $28 \ldots \ldots \ldots \ldots \ldots$ & $\cdots \cdots$ & 3483 & 3483 \\
\hline Week ending $M$ rarch $2 \ldots \ldots \ldots \ldots \ldots \ldots \ldots \ldots$ & 17742 & $\cdots \cdots$ & 17742 \\
\hline Week ending March $9 \ldots \ldots \ldots \ldots \ldots \ldots \ldots \ldots$ & 26293 & $\cdots \cdots$ & 16293 \\
\hline Wo k endite March its ,.......... & 14943 & $\cdots$ & 2.1643 \\
\hline Weck ending March $23 \ldots \ldots \ldots \ldots \ldots \ldots \ldots \ldots \ldots$ & 16522 & $\cdots \cdots:$ & 16522 \\
\hline Week ending March $30 \ldots \ldots \ldots \ldots \ldots \ldots \ldots . . . . . .$. & 17860 & $\cdots \cdots$ & 17860 \\
\hline Fifteen days ending March $15 \ldots \ldots \ldots \ldots \ldots \ldots$ & $\cdots \cdots$ & 3629 & 3629 \\
\hline 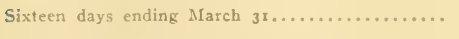 & (...... & $3^{8}>1$ & 3872 \\
\hline 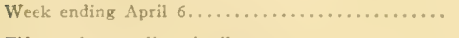 & 16430 & …. & 26430 \\
\hline Fifteen days ending April $r 5 \ldots \ldots \ldots \ldots \ldots \ldots$ & ...... & 3750 & 3750 \\
\hline 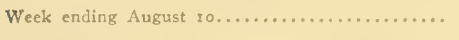 & 13100 & $\cdots \cdots$ & 13100 \\
\hline Week ending August $27 \ldots \ldots \ldots \ldots \ldots \ldots \ldots$ & 33750 & $\cdots \cdots$ & 13750 \\
\hline Week ending August $24 \ldots \ldots \ldots \ldots \ldots \ldots \ldots$. & 12900 & $\ldots \ldots$ & 32900 \\
\hline Week ending August $3 x \ldots \ldots \ldots \ldots \ldots \ldots \ldots . . . . . .$. & $x 4^{2} 50$ & $\cdots \cdots$ & 74250 \\
\hline Sixteen days ending August $31 \ldots . . . \ldots \ldots . . .$. & ...... & $3^{8} 71$ & 3872 \\
\hline Week ending September $7 \ldots \ldots \ldots \ldots \ldots \ldots \ldots$ & 12450 & $\cdots \cdots$ & 22450 \\
\hline Week ending September $14 \ldots \ldots \ldots \ldots \ldots \ldots \ldots$ & 13950 & $\cdots \cdots$ & 13950 \\
\hline Week ending September $21 . . . \ldots \ldots \ldots \ldots . . . . .$. & 23750 & $\cdots \cdots$ & $837 \mathrm{sc}$ \\
\hline Week ending September $28 . \ldots \ldots \ldots \ldots \ldots \ldots \ldots$ & 13750 & $\cdots \cdots$ & 13750 \\
\hline Fifteen days ending September $x 5 \ldots \ldots \ldots \ldots \ldots$ & $\cdots \cdots$ & 3750 & $37 \mathrm{sc}$ \\
\hline Fifteen days ending September $30 \ldots \ldots \ldots \ldots \ldots$ & $\cdots \cdots$ & - 3750 & 3750 \\
\hline Week ending October $5 \ldots \ldots \ldots \ldots \ldots \ldots \ldots \ldots$ & 10950 & $\cdots \cdots$ & 8095 \\
\hline Fifteen days ending October $15 \ldots \ldots \ldots \ldots \ldots \ldots$ & $\cdots \cdots$ & 3639 & 3628 \\
\hline Week ending November $16 \ldots \ldots \ldots \ldots \ldots \ldots . . . . .$. & 18700 & $\cdots \cdots$ & $187 \circ$ \\
\hline Week ending November $23 \ldots \ldots \ldots \ldots \ldots \ldots . . . . . .$. & 20400 & $\cdots \cdots$ & 2040 \\
\hline Week ending November $30 . \ldots . \ldots . \ldots . . . . . . .$. & 15500 & $\cdots \cdots$ & 2550 \\
\hline Fifteen days ending November $30 . \ldots \ldots \ldots \ldots \ldots$ & - $\ldots$ & 5000 & $50 \circ$ \\
\hline Week ending December $7 \ldots \ldots \ldots \ldots \ldots \ldots \ldots$ & 16050 & $\cdots \cdots$ & 1605 \\
\hline Week ending December $14 \ldots \ldots \ldots \ldots \ldots \ldots$ & 14826 & $\cdots \cdots$ & 1483 \\
\hline Fifteen days ending December $15 \ldots \ldots \ldots \ldots \ldots$ & $\cdots \cdots$ & $48 \quad 38$ & 483 \\
\hline , Total $., \ldots \ldots \ldots, \ldots, \ldots, \ldots, \ldots$ & $\$ 4,335 \quad 37$ & $\$ 51258$ & $\$ 4,8469$ \\
\hline
\end{tabular}


DEPARTMENT OF PARKS,

Statement shoceing paymenits on account of payrolls for Superintendent, Foremen, senarce Account:

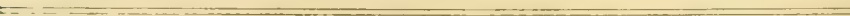

Period, 1906. $\frac{\text { Maintenance }}{\begin{array}{c}\text { Laborers, } \\ \text { etc., Weekly } \\ \text { Payroll. }\end{array}}$

Week ending Iuly 6

5. $.400=5$

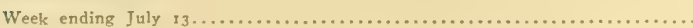

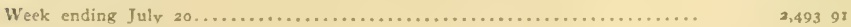

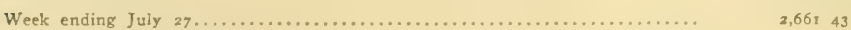

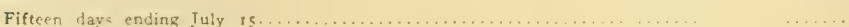

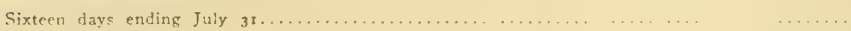

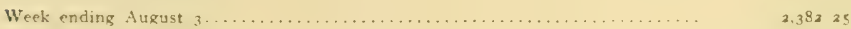

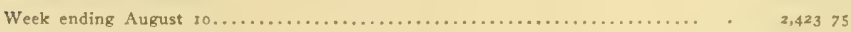

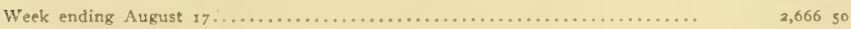

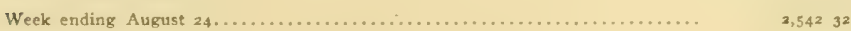

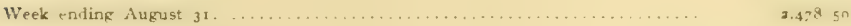

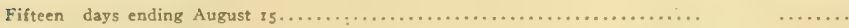

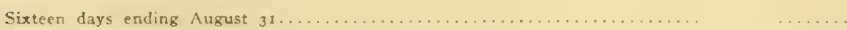

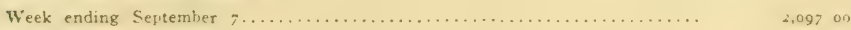

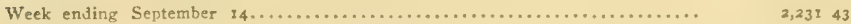

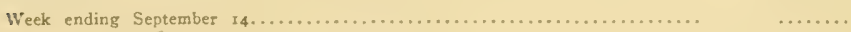

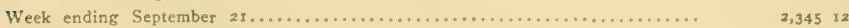

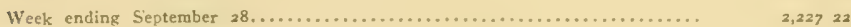

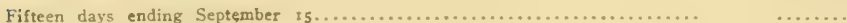

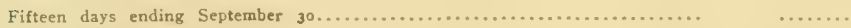

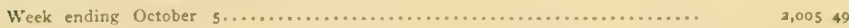

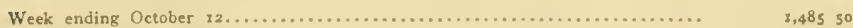

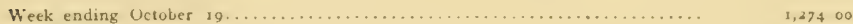

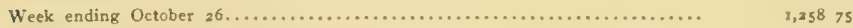

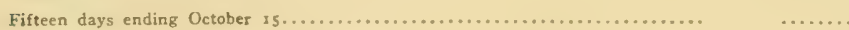

Sixteen days ending October $31 \ldots \ldots \ldots \ldots \ldots \ldots \ldots \ldots \ldots \ldots \ldots \ldots \ldots \ldots \ldots \ldots \ldots \ldots \ldots$

Week ending November $2, \ldots \ldots \ldots \ldots \ldots \ldots \ldots \ldots \ldots \ldots \ldots \ldots \ldots \ldots \ldots \ldots \ldots \ldots \ldots \ldots . . \ldots \ldots$

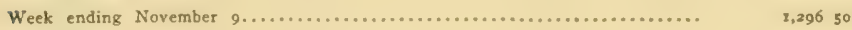

Week ending November $x 6 \ldots \ldots \ldots \ldots \ldots \ldots \ldots \ldots \ldots \ldots \ldots \ldots \ldots \ldots \ldots \ldots \ldots \ldots \ldots$

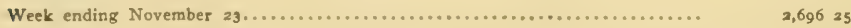


Schedule No. 3 B.

BOROUGH OF THE BRONX.

Laborers, etc., during 1906, charged to Special Revenue Futs for Deficit in Main-

\begin{tabular}{|c|c|c|c|c|c|}
\hline \multirow{2}{*}{$\frac{- \text { Deficit. }}{\begin{array}{c}\text { Superintendent, } \\
\text { Foremen, etc., } \\
\text { Semi-monthly } \\
\text { Payroll. }\end{array}}$} & \multicolumn{3}{|c|}{$\begin{array}{c}\text { Care of Trees in City Streets- } \\
\text { Deficit. }\end{array}$} & \multirow[b]{2}{*}{ Total. } & \multirow[b]{2}{*}{$\begin{array}{c}\text { Revenue } \\
\text { Bond. } \\
\text { Total. }\end{array}$} \\
\hline & Total. & $\begin{array}{l}\text { Laborers, } \\
\text { etc., Weekiy } \\
\text { Payroll. }\end{array}$ & $\begin{array}{l}\text { Superintendent, } \\
\text { Foremen, etc., } \\
\text { Semi-monthly } \\
\text { Payroll. }\end{array}$ & & \\
\hline ......... & $\$ 2,40925$ & ......... & ......... & ......... & $\$ 2,409=25$ \\
\hline ......... & $2,60 \times 25$ & $\cdots \cdots_{\alpha} \cdots$ & ........ & $\ldots \ldots \ldots$ & 2,60125 \\
\hline$\ldots \ldots \ldots$ & 2,493 gr & ......... & ........ & $\ldots \ldots \ldots$ & 2,49391 \\
\hline$\ldots . .$. & $2,66 \times 43$ & 80287 & ........ & $\$ 40287$ & 3,06430 \\
\hline$\$ 38704$ & 387.04 & ......... & ........ & $\ldots \ldots$ & 38704 \\
\hline 41296 & 41296 & n....... & ......... & $\ldots \ldots \ldots$ & 41296 \\
\hline ........ & a, 382,25 & 383 is & ........ & $383 \times 5$ & $2,765 \quad 40$ \\
\hline ....... & 2,42375 & $4 \times 635$ & n..... & $416 \quad 25$ & 2,840 oo \\
\hline$\ldots \ldots$ & 2,66650 & $486 \quad 25$ & $\ldots \ldots \ldots$ & $486 \quad 25$ & 3,15275 \\
\hline$\ldots \ldots \ldots$ & $2,542 \quad 32$ & $467 \quad 04$ & $\ldots \ldots \ldots$ & $467 \quad 04$ & 3,00936 \\
\hline ........ & 2,478 50 & 63225 & ........ & $622 \quad 25$ & $3,100 \quad 75$ \\
\hline 40704 & 407.04 & n...... & ........ & ....... & 40704 \\
\hline 41296 & 41296 & ........ & ....... & ....... & 41296 \\
\hline$\ldots . . \cdots$ & 2,09700 & 33750 & ......... & 53750 & 2,63450 \\
\hline$\ldots \ldots$ & $2,23 \pi \quad 43$ & 70150 & $\ldots \ldots \ldots$ & $70 \mathrm{r} 50$ & 2,93293 \\
\hline$\ldots \ldots$ & $\ldots \ldots \ldots$ & $\ldots \ldots \ldots$ & n....... & $\ldots \ldots \ldots$ & $\ldots \ldots \ldots$ \\
\hline$\ldots \ldots$ & $2,345 \quad 13$ & 70850 & $\ldots \ldots$ & 70850 & 3,05363 \\
\hline ......... & $3,237 \quad 23$ & $580 \quad 50$ & ......... & $980 \quad 50$ & $2,807 \quad 73$ \\
\hline 41250 & 41250 & ........ & ......... & ….... & 41250 \\
\hline 40000 & 40000 & ........ & ........ & $\ldots \ldots$ & 40000 \\
\hline n...... & 2,00549 & 69050 & ......... & 69050 & 2,69599 \\
\hline$\ldots \ldots$ & $\mathrm{r}, 48550$ & 90775 & $\ldots \ldots$ & 90775 & $2,393=5$ \\
\hline$\ldots \ldots$ & 1,27400 & $x, 06487$ & $\ldots \ldots$ & $8,064 \quad 87$ & $2,33^{8} \quad 87$ \\
\hline ....... & $1,258 \quad 75$ & 91555 & ......... & 91555 & 2,17430 \\
\hline $\begin{array}{lll}387 & 04\end{array}$ & 387 of & $\ldots \ldots$ & $\ldots \ldots$ & $\ldots \ldots \ldots$ & $\begin{array}{lll}387 & 04\end{array}$ \\
\hline $374: 4$ & 37424 & ........ & $\$ 3^{8} 7 x$ & $38 \quad 73$ & 45295 \\
\hline$\ldots \ldots$ & 1,32400 & 1,14850 & $\ldots \ldots$ & $x, 14850$ & $x, 47350$ \\
\hline$\ldots \ldots$ & $x, 29650$ & 1,06774 & $\ldots \ldots$ & 1,06774 & $3,364 \quad 24$ \\
\hline n....... & 89700 & $x, 80498$ & ....... & $x, 20498$ & $2,00: \quad 98$ \\
\hline ........ & 3,69625 & $1,827: 2$ & ......... & $3,127 \quad 12$ & $3,823 \quad 37$ \\
\hline
\end{tabular}


$=$

Maintenance

Period, I906.

Laborers,
etc. Weekly

etc., Week:

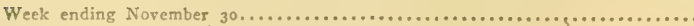

2,55800

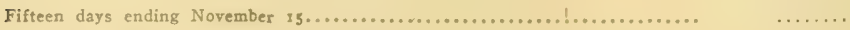

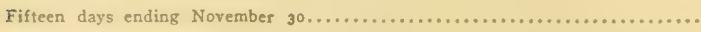

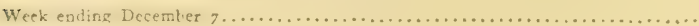

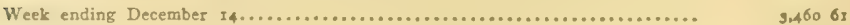

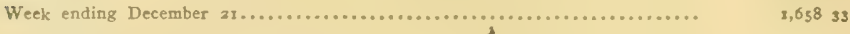

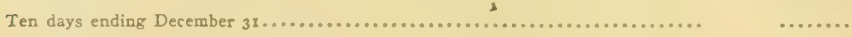

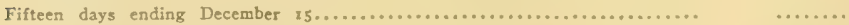

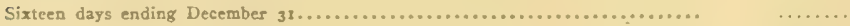

Totals............................................. \$54,451 73

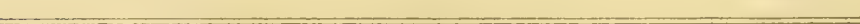


4.3

\begin{tabular}{|c|c|c|c|c|c|c|}
\hline \multirow{2}{*}{$\frac{- \text { Deficit. }}{\begin{array}{c}\text { Superintendent, } \\
\text { Foremen, etc., } \\
\text { Semi-monthly } \\
\text { Payroll. }\end{array}}$} & \multirow[b]{2}{*}{ Total. } & \multicolumn{2}{|c|}{$\begin{array}{c}\text { Carc of Trees in City Streets- } \\
\text { Deficit. }\end{array}$} & \multirow{2}{*}{\multicolumn{2}{|c|}{ Total. }} & \multirow[b]{2}{*}{$\begin{array}{l}\text { Revenue } \\
\text { Pond, } \\
\text { Iotal. }\end{array}$} \\
\hline & & $\begin{array}{l}\text { Laborers, } \\
\text { etc., Weekly } \\
\text { Payroll. }\end{array}$ & $\begin{array}{l}\text { Superintendent, } \\
\text { Foremen, etc,, } \\
\text { Semi-monthly } \\
\text { Payroll. }\end{array}$ & & & \\
\hline$\ldots \ldots \ldots$ & $\$ 2,55 \$ 00$ & $\$ 97500$ & $\ldots \ldots \ldots$ & $\$ 9750$ & 00 & $\$ 3.53300$ \\
\hline$\$ 412 \quad 50$ & 41250 & $\ldots \ldots \ldots$ & $\$ 13750$ & 137 & 50 & 5500.7 \\
\hline$x, 30500$ & 1,30500 & $\ldots \ldots \ldots$ & 13750 & I 375 & 50 & 1,44250 \\
\hline$\ldots \ldots$ & $2,977 \quad 37$ & $716 \quad 12$ & $\ldots \ldots$ & 716 & 12 & 3.69340 \\
\hline ......... & $3,4606 \mathrm{I}$ & $348 \quad 25$ & $\ldots \ldots \ldots$ & $344^{S}=$ & 25 & $3,808 \quad 80$ \\
\hline$\ldots \ldots \ldots$ & $1,658,33$ & 52458 & $\ldots \ldots \ldots$ & 5245 & $5^{8}$ & 2,18291 \\
\hline$\ldots \ldots \ldots$ & , . . . . & 404 or & ......... & 404 & 01 & 40401 \\
\hline $1,444 \times 9$ & 1,44419 & $\ldots \ldots \ldots$ & $\ldots \ldots$ & n.... & $\cdots$ & $1,444 \quad 10$ \\
\hline ........ & ......... & ........ & 5162 & 51 & .62 & S1 62 \\
\hline$\$ 6,35547$ & $\$ 60,80720$ & $\$ 16,30078$ & $\$ 36533$ & $\$ 16,666$ & II & $\$ 77,473 \quad 31$ \\
\hline
\end{tabular}


Payroll Schedule No. 4 B.

DEPARTMENT OF PARKS, BOROUGH OF THE BRONX.

Payments on account of payrolls during igo6 on account of payrolls for Superintendent, Foremen, Engineers, Laborers, etc., charged against Corporate Stock Funds for Construction and Improvemenit of Parks, etc.:

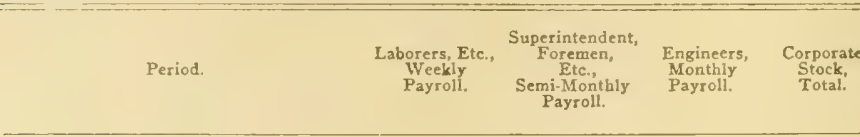

I906.

Five days ending January $5 . . \ldots \ldots \ldots \ldots$

Week ending January $12 \ldots \ldots \ldots \ldots \ldots$

Week ending January $19 . . . . . . \ldots . .$.

Week ending January $26 \ldots \ldots \ldots \ldots \ldots$.

Fifteen days ending January $15 \ldots . . . \ldots$.

Sixteen days ending January $3 x \ldots . . .$.

Month ending January $3 t . . . . . . . . . .$.

Week ending February 2..............

Week ending February 9..............

Week ending February $16 \ldots \ldots \ldots \ldots$.

Week ending February 23.............

Fifteen days ending February $35 \ldots \ldots \ldots$

Thirteen days ending February $28 \ldots \ldots$.

Month ending February $28 \ldots \ldots \ldots \ldots$.

Week ending March $2 \ldots \ldots \ldots \ldots \ldots$.

Week ending March $9 . . . \ldots \ldots \ldots \ldots$.

Week ending March $16 \ldots \ldots \ldots \ldots \ldots$

Week ending March a $3 \ldots \ldots \ldots \ldots \ldots$.

Week ending March $30 . . \ldots \ldots \ldots \ldots$.

Fifteen days ending March $\$ 5 \ldots \ldots \ldots$.

Sixteen days ending March 3 z..........

Month ending March $3 x \ldots . . . \ldots \ldots . . .$.

Week ending April $6 \ldots . . . \ldots \ldots . .$.

Week ending April $13 \ldots . . . \ldots \ldots . . .$.

Week ending April $20 . . . . . . . . . .$.

Week ending April a7................

Fifteen days ending April $85 . . . . . . .$.

Fifteen days ending Apsil $30 \ldots . . \ldots \ldots$

Month ending April 30 .
$\$ 2,0964$

$2,964 \quad 73$

41322

46962

.......

$\ldots \ldots$

......

$932 \quad 17$

1, $088 \quad 62$

3,51295

2.74284

…...

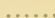

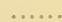

I, 836 og

$8,88,72$

$x, 71482$

$888 \quad 83$

3,63510

......

$\ldots \ldots$

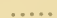

8,83353

3,628 20

3,06595

$2,9663 x$

…...

......
.....

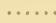

$\$ 2,09641$

3,96473

$413=2$

46962

$\begin{array}{lll}387 & 04\end{array}$

$258 \times 0$

10967

$932 \times 7$

1,08862

$x, 51295$

$I, 74284$

37499

37499

325 ox

f.....

.......

$3250 x$

$10000 \quad 10000$

..... $\quad x, 836$ o9

…. $\quad 1,88_{3} 72$

..... I.7 1442

-.....

…..

......

$888 \quad 83$

$x, 63510$

33866

(

33866

36134

36 I 34

.......

(.....

10000

10000

$x, 83353$

......

3,618 20

$\ldots \ldots$

......

3,06595

.....

2,966 38

40000

......

40000

45000

45000

...... 


\begin{tabular}{|c|c|c|c|c|}
\hline Period. & $\begin{array}{c}\text { Laborers, Etc., } \\
\text { Weekly } \\
\text { Payroll. }\end{array}$ & $\begin{array}{l}\text { Superintendent, } \\
\text { Foremen, } \\
\text { Etc., } \\
\text { Semi-Montbly } \\
\text { Payroll. }\end{array}$ & $\begin{array}{l}\text { Engineers, } \\
\text { Monthly } \\
\text { Payroll. }\end{array}$ & $\begin{array}{l}\text { Corporate } \\
\text { Stock, } \\
\text { Total. }\end{array}$ \\
\hline 1906. & & & & \\
\hline Week ending May $4 \ldots \ldots \ldots \ldots \ldots \ldots \ldots$ & a,559 as. & $\cdots \cdots$ & $\cdots \cdots$ & 2,55925 \\
\hline Week ending May $11 \ldots \ldots \ldots \ldots \ldots$ & 2,21621 & $\cdots \cdots$ & $\cdots \cdots$ & 2,21621 \\
\hline Week ending May $\mathbf{8}, \ldots \ldots \ldots \ldots \ldots$ & 2.92930 & $\cdots \cdots$ & $\cdots \cdots$ & 8,92936 \\
\hline Week ending May $25 \ldots \ldots \ldots \ldots \ldots . . . .$. & 3,18290 & … & $\cdots \cdots$ & 3,1829 \\
\hline Fifteen days ending May $15 \ldots \ldots \ldots \ldots$ & $\cdots \cdots$ & 33866 & $\cdots \cdots$ & 3386 \\
\hline Sixteen days ending May $31 \ldots \ldots \ldots \ldots$ & $\cdots \cdots$ & 36134 & $\cdots \cdots$ & $36 \times 3$ \\
\hline Month ending May $31 \ldots \ldots \ldots \ldots \ldots$ & $\cdots \cdots$ & $\cdots \cdots$ & 20000 & $200 \circ$ \\
\hline Week ending June,$\ldots \ldots \ldots \ldots \ldots \ldots$ & 2,32420 & $\cdots \cdots$ & $\cdots \cdots$ & 2,3242 \\
\hline Week ending June $8 \ldots \ldots \ldots \ldots \ldots \ldots$ & $3,056,32$ & $\cdots \cdots$ & $\cdots \cdots$ & 3,0563 \\
\hline Week ending June r $\ldots \ldots \ldots \ldots \ldots \ldots$ & $9, \times 79 \quad 83$ & $\cdots \cdots$ & $\cdots \cdots$ & 3,1791 \\
\hline Week ending June $32 \ldots \ldots \ldots \ldots \ldots . . . .$. & $2,188 \quad 57$ & $\cdots \cdots$ & $\cdots \cdots$ & $2,188 \quad 5$ \\
\hline Weck ending June $29 . \ldots \ldots \ldots \ldots \ldots$. & 2,94919 & $\cdots \cdots$ & $\cdots \cdots$ & $2,949 \quad \mathrm{I}$ \\
\hline Fifteen days ending June $15 \ldots \ldots \ldots \ldots$ & $\cdots \cdots$ & 50000 & $\cdots \cdots$ & 5000 \\
\hline Fifteen days ending June $30 \ldots \ldots \ldots \ldots$ & $\cdots \cdots$ & 50000 & $\cdots \cdots$ & $500 \circ$ \\
\hline Month ending June $30 \ldots \ldots \ldots \ldots \ldots$ & $\cdots \cdots$ & $\cdots \cdots$ & 10000 & 1000 \\
\hline Week ending July $6 \ldots \ldots \ldots \ldots \ldots \ldots$ & $2.547 \times 7$ & $\cdots \cdots$ & $\cdots \cdots$ & $2,547 \times$ \\
\hline Week ending July r $3 \ldots \ldots \ldots \ldots \ldots \ldots$ & $3.033 \quad 18$ & $\cdots \cdots$ & $\cdots \cdots$ & $3,033 \quad$ \\
\hline Week ending July $20 \ldots \ldots \ldots \ldots \ldots \ldots$ & $2,830 \quad 49$ & $\cdots \cdots$ & $\cdots \cdots$ & $2,830 \quad 4$ \\
\hline Week ending July $27 \ldots \ldots \ldots \ldots \ldots \ldots$ & 3,00684 & $\cdots \cdots$ & $\cdots \cdots$ & 3,0068 \\
\hline Fifteen days ending July $19 . . . \ldots \ldots \ldots$ & ..... & 48380 & $\cdots \cdots$ & $48_{3} 8$ \\
\hline Sixteen days ending July $31 . . . \ldots \ldots \ldots$ & $\cdots \cdots$ & 51620 & $\cdots \cdots$ & 5162 \\
\hline Month ending July $3 x \ldots \ldots \ldots \ldots \ldots$. & - w & $\cdots \cdots$ & 10000 & 1000 \\
\hline Week ending August $3 \ldots \ldots \ldots \ldots \ldots$ & $3,36 \times 25$ & $\cdots \cdots$ & $\cdots \cdots$ & $2,361=$ \\
\hline 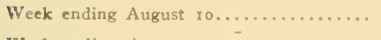 & $2.747 \times 5$ & $\ldots \ldots$ & $\cdots \cdots$ & $2,747=$ \\
\hline Week ending August $17 \ldots \ldots \ldots \ldots . . . .$. & 3,01745 & $\cdots \cdots$ & $\cdots \cdots$ & 3,0174 \\
\hline Week ending August $34 \ldots \ldots \ldots \ldots \ldots$ & $3,875 \quad 10$ & - w. & $\cdots \cdots$ & $2,875=$ \\
\hline Week ending August $31 \ldots \ldots \ldots \ldots \ldots$ & $2,893 \quad 45$ & $\cdots \cdots$ & $\cdots \cdots$ & 2,8934 \\
\hline Fifteen days ending August $15 \ldots \ldots \ldots$ & $\cdots \cdots$ & 48380 & $\cdots \cdots$ & 4838 \\
\hline Sixteen days ending August $31 \ldots \ldots \ldots$ & $\cdots \cdots$ & 51620 & $\cdots \cdots$ & 5162 \\
\hline Month ending August $3 x \ldots \ldots \ldots \ldots \ldots$ & $\cdots \cdots$ & $\cdots \cdots$ & 10000 & 1000 \\
\hline Wcek ending September $7 \ldots \ldots \ldots \ldots \ldots$ & 3,52120 & $\cdots \cdots$ & $\cdots \cdots$ & 2,5212 \\
\hline Week ending September $\$ 4 \ldots \ldots \ldots \ldots$ & $3,150 \times 22$ & $\cdots \cdots$ & $\cdots \cdots$ & $3,150=$ \\
\hline Week ending September $22 . \ldots . \ldots . .$. & 3,19589 & $\cdots \cdots$ & $\cdots \cdots$ & 3,1958 \\
\hline Week ending September $28 \ldots \ldots \ldots \ldots$. & $3,8,3503$ & ..... & ...... & 2,835 \\
\hline
\end{tabular}




\begin{tabular}{|c|c|c|c|c|}
\hline Period. & $\begin{array}{c}\text { Laborers, Etc., } \\
\text { Weekly } \\
\text { Rayroll. }\end{array}$ & $\begin{array}{c}\text { Superintendent, } \\
\text { Foremen, } \\
\text { Etc., } \\
\text { Semi-Monthly } \\
\text { Payroll. }\end{array}$ & $\begin{array}{l}\text { Engineers, } \\
\text { Monthly } \\
\text { Payroll. }\end{array}$ & $\begin{array}{l}\text { Corporate } \\
\text { Stock, } \\
\text { Total. }\end{array}$ \\
\hline
\end{tabular}

1906.

Fifteen days ending September $15, \ldots . .$. Fifteen days ending September $30 \ldots \ldots \ldots$ Month ending September $30 \ldots . . \ldots \ldots$.

Week ending October $5 \ldots \ldots \ldots \ldots \ldots \ldots$

Week ending October $12 \ldots . . \ldots \ldots . . .$.

Week ending October $19 . . . . . . . . .$.

Week ending October $26 \ldots \ldots \ldots \ldots . .$.

Fifteen days ending October $15 \ldots . . . .$.

Sixteen days ending October $3 x \ldots \ldots \ldots$

Month ending October $3 x \ldots . . \ldots \ldots \ldots$.

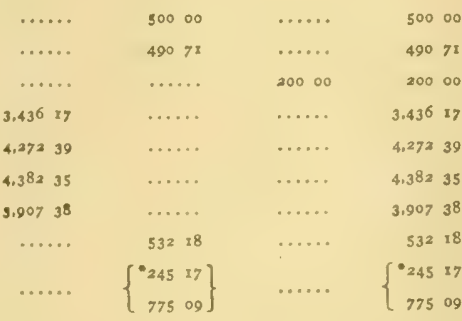

Week ending November $2, \ldots \ldots \ldots \ldots .$.

..... 20.2000000

Week ending November 9.............

\section{$4,320 \quad 33$}

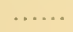

...... 4,32033

\section{$4,365 \quad 12$}

Week ending November $16 \ldots . . . . .$.

Week ending November $23 . . . \ldots . . . . .$.

$4,6 \geq 8,76$

$\ldots \ldots$

$\cdots \ldots$

4,36512

4.91787

$\ldots \ldots$

$\ldots \ldots$

$4,6 \times 8,76$

Week ending November $30 . . . . . . . .$.

4,775 o6

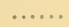

$\ldots \ldots$ 4,91787

\section{......}

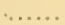

.....

4.77506

Fifteen days ending November r5.......

Fifteen days ending November $30 . . . .$.

Month ending November $30 . . . . . . .$.

$\ldots \ldots$

97500

$\ldots \ldots$

97500

......

$x, 02500$

Week ending December $7 \ldots . . . . . .$.

$5,691 \pm 9$

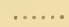

-......

1,02500

Week ending December $14 \ldots . . . . . .$.

\section{$6,474,43$}

$\left\{\begin{array}{rr}5.402 & 44 \\ 21 & 00\end{array}\right\}$

$5.946 \quad 72$

......

9980

20000 30000 $5.691 \times 9$ 6,47442

Week ending December ar............

Fifteen days ending December $15 . . . .$.

Sixteen days ending December $38 \ldots . . .$.

Month ending December $31 . . . \ldots \ldots . .$.

\section{t... $\quad 03884$}

$\ldots . .$.

.... $\left\{\begin{array}{rr}5,402 & 44 \\ 0 & 00\end{array}\right.$ 5,94672

$\ldots \ldots$

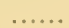
$99 \times 80$ 1,03884

$20000 \quad 20000$

$\begin{array}{lllll}\$ 53,78370 & \$ 13,16893 \quad \$ 1,70967 & \$ 168,66230\end{array}$ 

DEPARTMENT OF PARKS,

Summary showing payroll payments during 1906 for Superintendent, Engineers,

\section{Period Ending}

1906.

Five days inding January 5

Week ending January 12

Weck ending lanuary 19

Week ending January 26 .

Fifteen days ending January 15

Sixteen day ending January 31.

Month ending Tanuary $3 \mathrm{I}$.

Week w whing Trbriary 2.

Week ending February 9 .

Weck ending lebruary in

Wiek endus February z 3 .

Fifteen days ending February 15

Thirteen days ending February 28

Month endinz February as. . .

Week ending March 2.

Week en.hng March $9 .$.

Week ending March 36 .

Week ending March $23 .$.

Week ending March 30

Fiftecn days enciing March 15

Sixteen days ending March 31

Month ending March $3 t$.

Week ending Intil 6 .

Week ending April 13.

Week ending April 20.

Week ending April 27

Fifteen days ending April 15

Fifteen days ending April 30

Month ending April $30 .$.

Week ending May

Week ending May 
Schedule No. 5B.

BOROUGH OF THE BRONX.

Foremen, Gardeners, Ifcchanics, Laborcrs, ctc., charged against all accounts:

Budget Appropriation Accounts.

\begin{tabular}{|c|c|c|c|c|c|}
\hline $\begin{array}{c}\text { Maintenance } \\
\text { and Construction } \\
\text { Account. }\end{array}$ & $\begin{array}{l}\text { Forestry } \\
\text { WVork } \\
\text { Account. }\end{array}$ & $\begin{array}{l}\text { Total } \\
\text { l3udget } \\
\text { Charges. }\end{array}$ & $\begin{array}{l}\text { Special } \\
\text { Revenue } \\
\text { Bond Funds } \\
\text { for Deficit. }\end{array}$ & $\begin{array}{l}\text { Corporate Stock } \\
\text { Funds for } \\
\text { Improvement } \\
\text { of Parks, Eitc. }\end{array}$ & $\begin{array}{c}\text { Total } \\
\text { Against All } \\
\text { Accounts. }\end{array}$ \\
\hline$\$ 4,1$ So $=5$ & $\$ 19350$ & $\$ 4.37375$ & $\cdots \cdots \cdots$ & $\$ 2,096 \quad 4 \pi$ & $\$ 6,470 \quad 16$ \\
\hline $5.970 \quad 93$ & 29750 & $0,26 \mathrm{~S} \quad 43$ & $\ldots \ldots$ & 2,96473 & $9,233 \quad 16$ \\
\hline $3,199 \quad 37$ & $\ldots \ldots$ & 3.19937 & $\ldots \ldots$ & 41322 & 3,61259 \\
\hline 3.33974 & 18400 & $3,523 \quad 74$ & $\ldots \ldots \ldots$ & 46962 & $3.993 \quad 36$ \\
\hline 1,24135 & $30 \quad 99$ & $1,278 \quad 37$ & $\ldots \ldots$ & $\begin{array}{lll}387 & 04\end{array}$ & $I, 6654 \mathrm{I}$ \\
\hline $1,450+8$ & 3871 & $1,489 \quad 19$ & $\ldots \ldots \ldots$ & 25810 & $1.747 \quad 29$ \\
\hline$\ldots \ldots$ & $\ldots \ldots \ldots$ & $\ldots \ldots$ & $\ldots \ldots \ldots$ & 10967 & $\log 67$ \\
\hline $3.790 \quad 74$ & 11500 & $3.905 \quad 74$ & $\ldots \ldots \ldots$ & $932 \quad 17$ & 4,83791 \\
\hline $3.62+10$ & 13374 & $3.757 \quad 84$ & $\ldots \ldots \ldots$ & $1,0886 z$ & 4,84646 \\
\hline 2.80299 & $1 \$_{3} 74$ & $2,986 \quad 73$ & $\ldots \ldots$ & $\mathrm{I}, 51295$ & 4,49968 \\
\hline 2,87330 & 18673 & $3,060 \quad 03$ & $\ldots \ldots$ & 1,74284 & 4,80287 \\
\hline I, 398 I 3 & $40 \quad 17$ & $1,438 \quad 30$ & 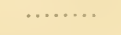 & $374^{\circ} 99$ & $x, 8 \mathrm{r} 3=9$ \\
\hline I, 21187 & 3483 & $I, 24670$ & $\ldots \ldots$ & 325 oI & $3,57 \times 71$ \\
\hline$\ldots \ldots$ & $\ldots \ldots$ & $\ldots \ldots$ & $\ldots \ldots$ & 10000 & 10000 \\
\hline 2.90606 & 17742 & $3,08_{3} 48$ & $\ldots \ldots \ldots$ & $x, 836 \circ 9$ & 4,91957 \\
\hline 2.93375 & 16293 & $3,096 \quad 68$ & $\ldots \ldots \ldots$ & $x, 8 S_{3} \quad 72$ & 4.98040 \\
\hline $2,912 \quad 50$ & $149 \quad 43$ & $3,061 \quad 93$ & $\ldots \ldots$ & 1,71482 & 4.77675 \\
\hline $2.965 \quad 37$ & 16522 & $3,130 \quad 59$ & . . . & $8888_{3}$ & 4,0194 \\
\hline $3.029 \quad 24$ & I 7860 & 3.20784 & $\ldots \ldots$. & $x, 635 \quad 10$ & $4,8,4294$ \\
\hline 1,26276 & 3629 & $x, 29905$ & $\ldots \ldots \ldots$ & $33^{8} 66$ & 7,6377 \\
\hline $1.4666 \mathrm{r}$ & $3^{S} 7 x$ & 1,50532 & $\ldots \ldots \ldots$ & $361 \quad 34$ & 3,8666 \\
\hline$\ldots \ldots$ & $\cdots \cdots \cdots$ & $\ldots \ldots \ldots$ & $\because \ldots \ldots$ & 10000 & 1000 \\
\hline $3.069 \times 2$ & 16430 & $3,23,42$ & $\ldots \ldots \ldots$ & $\mathrm{J}, 83353$ & 5,0669 \\
\hline 4,698 o9 & $\ldots \ldots \ldots$ & $4,698 \circ 9$ & $\ldots \ldots \ldots$ & $3,618 \quad 20$ & 8,316 ac \\
\hline $5.553 \quad 50$ & $\ldots \ldots$ & $5.553 \quad 50$ & $\ldots \ldots \ldots$ & 3,06595 & 8,6194 \\
\hline $5,127 \quad 59$ & $\ldots \ldots \ldots$ & 5,12759 & $\ldots \ldots \ldots$ & 2,96631 & 8,0939 \\
\hline 1,40500 & 3750 & $\mathrm{I}, 44250$ & $\ldots \ldots \ldots$ & 40000 & $x, 842 \quad 5$ \\
\hline 1,39250 & $\ldots \ldots$ & $x, 39250$ & $\ldots \ldots$ & 45000 & $x, 8425$ \\
\hline$\cdots \ldots$ & $\ldots \ldots \ldots$ & $\ldots \ldots \ldots$ & $\ldots \ldots$ & 10000 & . 1000 \\
\hline 6,10368 & $\ldots \ldots$ & $6,1 \circ 368$ & $\ldots \ldots \ldots$ & $2,559 \quad 25$ & 8,6629 \\
\hline 5,91423 & $\ldots \ldots$ & 5.91423 & 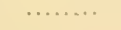 & 2,21621 & 8,1304 \\
\hline
\end{tabular}


Week ending May 18 ...

Weck emeler Yas :

Iifteet, lays enting May is

Sixteen days ending May 31

Mumth emlute M!ay 31 ....

Week ending June $\mathrm{I}$

Week ending June $x$

Week ending June 15.

Week ending June 22

Wek endrg I unte an.

Fifteen ilas exhere Tare

Fifteen days ending June 30

Month emine June 31 ..

Week endine Jaly o

Week ending Iuiy 13

Week enturg Iuly zo.

Week colning July :- .

Fifteen dayn cisleng Juty is.

Sixterm dass endime Iuly 3 i

Aronth wriling July 31

Weeh enderg Iuxu-t

Wiek exrase hew 1.

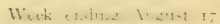

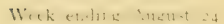

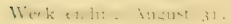

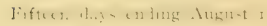

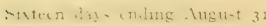

Month ending August 31 . . .

Week ending September ?

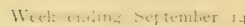

Week ending september 21 . .

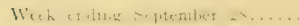

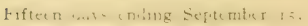

Fifteen has whing Sertember

Ximel. ewhe seytemter 3. 


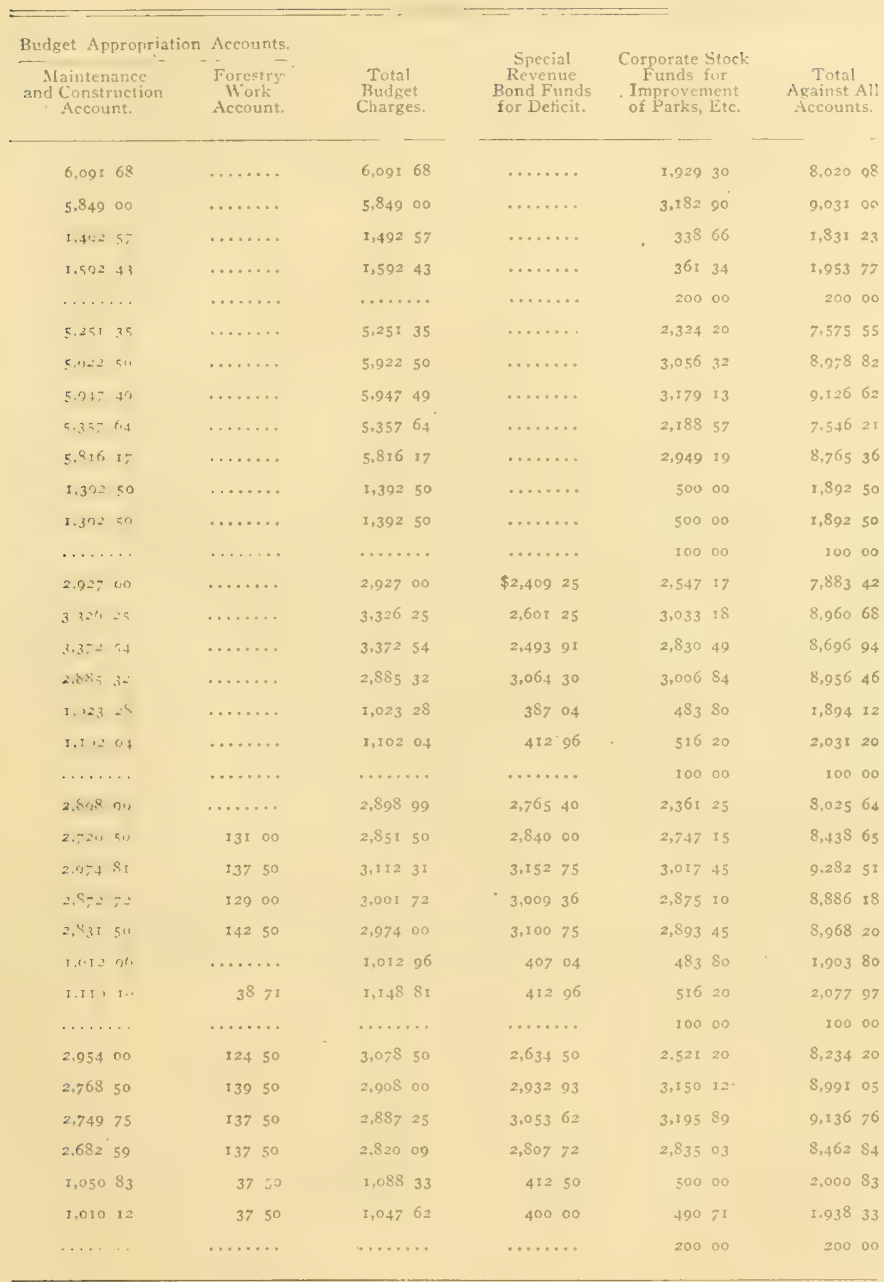




\section{Period Ending}

Week ending October

Week ending October

Week ending October

Week ending October it.

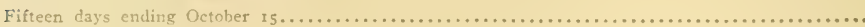

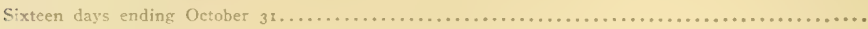

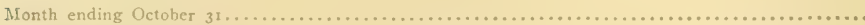

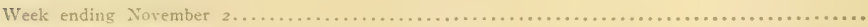

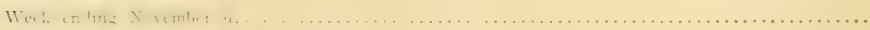

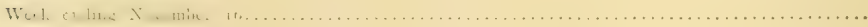

Weeh s nhm $\times$.

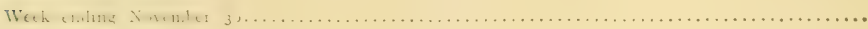

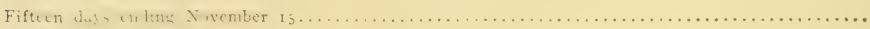

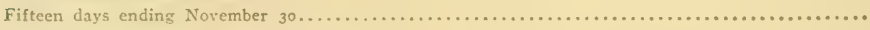

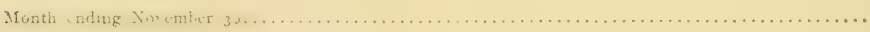

Week ending December 7 .

Week urding Nocumber it. . .

Week ending December z $\mathrm{x}$....

Ten days ending December 3 r....

Fifteen days ending December 15.

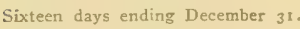

Month ending December $3 \mathrm{I}$..... 


\begin{tabular}{|c|c|c|c|c|c|}
\hline $\begin{array}{l}\text { Budget Appropria } \\
\text { Maintenance } \\
\text { and Construction } \\
\text { Account. }\end{array}$ & $\begin{array}{l}\text { Accounts. } \\
\text { Forestry } \\
\text { Work } \\
\text { Account. }\end{array}$ & $\begin{array}{c}\text { Total } \\
\text { Budget } \\
\text { Charges. }\end{array}$ & $\begin{array}{l}\text { Special } \\
\text { Revenue } \\
\text { Bond Funds } \\
\text { for Deficit. }\end{array}$ & $\begin{array}{c}\text { Corporate Stock } \\
\text { Funds for } \\
\text { Improvement } \\
\text { of Parks. Etc. }\end{array}$ & $\begin{array}{c}\text { Total } \\
\text { Against All } \\
\text { Accounts. }\end{array}$ \\
\hline $2.495 \quad 63$ & 10950 & $2,605 \mathrm{I} 3$ & 2,69599 & $3.436 \quad 17$ & 8,73729 \\
\hline 2,34200 & $\ldots \ldots \ldots$ & 2,34200 & $2.393 \quad 25$ & $4.272 \quad 39$ & 9.00764 \\
\hline $2.33900^{\circ}$ & $\ldots \ldots \ldots$ & 2,33900 & 2.33887 & $4.3^{82} \quad 35$ & $9,060 \quad 22$ \\
\hline $2,340 \quad 50$ & $\ldots \ldots$ & 2.340 .50 & $2,174 \quad 30$ & $3.907 \quad 38$ & $8.422 \times 8$ \\
\hline 1.08295 & $36 \quad 29$ & 1,11924 & $\begin{array}{lll}387 & 04\end{array}$ & $532 \quad 18$ & $2.038 \quad 46$ \\
\hline $3,011 \quad 72$ & $\ldots \ldots$ & 1,01172 & 41295 . & $x, 020^{\circ}=6$ & 2,44493 \\
\hline$\ldots \ldots \ldots$ & $\ldots \ldots$ & $\ldots \ldots$ & $\ldots \ldots \ldots$ & 20000 & 20000 \\
\hline $2,347 \quad 52$ & $\ldots \ldots \ldots$ & $2,347 \quad 52$ & 2,47250 & 4.31033 & $9,130 \quad 35$ \\
\hline $2,355 \quad 12$ & $\ldots \ldots$ & 2,355 i2 & 2,36424 & $4,365 \quad 12$ & $9,084 \quad 48$ \\
\hline 1,19298 & 18700 & $I, 37998$ & $2,00 \times 98$ & $4,618,76$ & 8.00072 \\
\hline$\ldots \ldots$ & 20400 & 20400 & $3,823 \quad 37$ & 4.91787 & $8,945 \quad 24$ \\
\hline$\ldots \ldots \ldots$ & 15500 & 15500 & 3.53300 & $4,775 \quad 06$ & 8,463 of \\
\hline $1, I 19 \quad 16$ & $\ldots \ldots \ldots$ & I, II9 I 6 & 55000 & 97500 & $2,644 \quad 16$ \\
\hline$\ldots \ldots$ & 5000 & $50 \quad 00$ & 1,44250 & 1,02500 & 2.51750 \\
\hline$\ldots \ldots$ & $\cdots \cdots$ & $\ldots \ldots$ & $\ldots \ldots$ & 20000 & 20000 \\
\hline$\ldots \ldots \ldots$ & 16050 & $360 \quad 50$ & $3.693 \quad 49$ & $5,691 \quad 19$ & $9.345 \times 8$ \\
\hline$\ldots \ldots \ldots$ & 14826 & 14826 & $3,808 \quad 86$ & $6,474 \quad 42$ & $10,431 \quad 54$ \\
\hline 1,79991 & $\ldots \ldots \ldots$ & 1,79991 & 2,18291 & $5.423 \quad 44$ & $9.406 \quad 26$ \\
\hline $5,978 \quad 16$ & $\ldots \ldots \ldots$ & $5,978 \quad 16$ & 404 or & $5.946 \quad 72$ & $12,328 \quad 89$ \\
\hline$\ldots \ldots$ & $4^{8} \quad 3^{8}$ & $4^{8} 3^{8}$ & $1,444 \quad 19$ & 99180 & 2,48437 \\
\hline$x, 571 \quad 45$ & $\ldots \ldots$ & $1,571 \quad 45$ & 5162 & 1,03884 & 2,661 9I \\
\hline$\ldots \ldots$ & $\ldots \ldots$ & $\ldots \ldots \ldots$ & $\ldots \ldots$ & $200 \quad 00$ & 20000 \\
\hline$\$ 204,179$ or & $\$ 4,84695$ & $\$ 209,02596$ & $\$ 77,4733^{x}$ & $\$ 168,66230$ & $\$ 455,161 \quad 57$ \\
\hline
\end{tabular}


Payroll Scihedule No. 6B.

DEPARTMENT OF PARKS, BOROUGH OF THE BRONX.

Showing payroll payments, January I to August 3I, I907, for scrvices of Superinitendent, Engincers, Foremen, Laborers, etc., charged against Budget Appropriation Accounts, Maintenance and Construction:

\begin{tabular}{|c|c|c|c|}
\hline Period Ending & $\begin{array}{l}\text { Laborers, etc., } \\
\text { Weekly } \\
\text { Payroll. }\end{array}$ & $\begin{array}{c}\text { Superintendent, } \\
\text { Foremen, } \\
\text { etc., } \\
\text { Semi-Monthly } \\
\text { Payroll. }\end{array}$ & Total. \\
\hline Four days ending January $4 \ldots \ldots \ldots \ldots \ldots \ldots \ldots \ldots \ldots \ldots$ & $\$ 4,080 \quad 18$ & $\cdots \cdots \cdots$ & $\$ 4,080 \times 8$ \\
\hline Week ending January $11, \ldots \ldots \ldots \ldots \ldots \ldots \ldots \ldots \ldots \ldots \ldots \ldots \ldots$ & $7,888 \quad I_{3}$ & $\ldots \ldots \ldots$ & $7,888 \quad 13$ \\
\hline 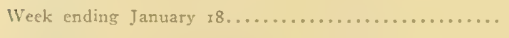 & $5,8 \times 31$ & n....... & $5,8103^{x}$ \\
\hline 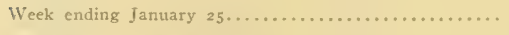 & $4.593 \quad 12$ & $\ldots \ldots \ldots$ & $4.593 \quad 12$ \\
\hline Intues days enting Tannary $15, \ldots \ldots \ldots \ldots \ldots \ldots \ldots$ & $\ldots \ldots$ & $\$ 2,01256$ & 2,01256 \\
\hline Sixtern days ending Jannary $31 \ldots \ldots \ldots \ldots \ldots \ldots$ & $\ldots \ldots$ & $2,176 \quad 37$ & 2,17637 \\
\hline Muntls ending Ianuary $31 \ldots \ldots \ldots \ldots \ldots \ldots \ldots \ldots \ldots$ & $\ldots \ldots$ & $\ldots \ldots$ & ........ \\
\hline Week ending February $x . . . \ldots \ldots$. & 8,56749 & $\ldots \ldots \ldots$ & 8,56749 \\
\hline 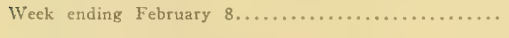 & 5.96625 & $\cdots \cdots \cdots$ & $5,966 \quad 25$ \\
\hline Week ending February $15 \ldots \ldots \ldots \ldots \ldots \ldots \ldots \ldots \ldots \ldots$ & 3,02146 & $\ldots \ldots \cdots$ & $3,02 \times 46$ \\
\hline 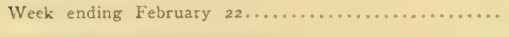 & 3,25402 & $\cdots \cdots \cdots$ & 3,25402 \\
\hline Fifteen days ending February $15 \ldots \ldots \ldots$. & $\cdots \cdots$ & 2,19898 & 2,19898 \\
\hline Thirteen days ending February $28 \ldots \ldots \ldots \ldots \ldots \ldots \ldots$ & $\cdots \cdots$ & 1,93555 & 1,93855 \\
\hline Month ending Feliruars $28, \ldots \ldots \ldots$. & $\cdots \cdots$ & $\ldots \ldots \ldots$ & ......... \\
\hline 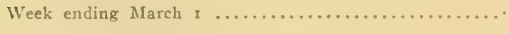 & $3.9377 \mathrm{I}$ & $\cdots \cdots \cdots$ & $3.937 \quad 78$ \\
\hline 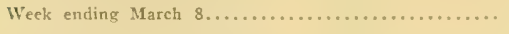 & 3.52968 & $\ldots \ldots \ldots$ & 3.52968 \\
\hline 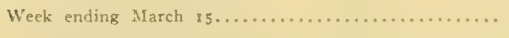 & 3,60702 & $\ldots \ldots \ldots$ & 3,60702 \\
\hline 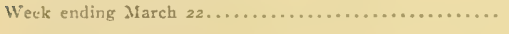 & $3,617 \quad 39$ & $\cdots \cdots \cdots$ & $3,6 \pm 7 \quad 39$ \\
\hline 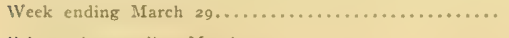 & $4,173 \quad 74$ & $\cdots \cdots \cdots$ & 4,17374 \\
\hline 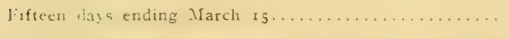 & $\cdots \cdots$ & 2,18521 & 2,18521 \\
\hline Sixteen days ending March $3 z \ldots \ldots \ldots \ldots \ldots \ldots \ldots$ & $\cdots \cdots$ & 2,33459 & 2,33459 \\
\hline Month ending March $32 \ldots \ldots \ldots \ldots \ldots \ldots \ldots \ldots \ldots \ldots \ldots \ldots \ldots \ldots$ & (...... & $\cdots \cdots \cdots$ & $\ldots \ldots \ldots$ \\
\hline Week ending April $5 \ldots \ldots \ldots \ldots$ & $4,035 \quad 50$ & $\cdots \cdots+$ & 4,03550 \\
\hline 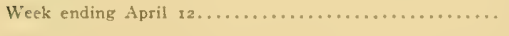 & 4,10175 & $\cdots \cdots \cdots$ & 4,10175 \\
\hline Week ending Arril $19 . \ldots \ldots \ldots$. & $4.390 \quad 05$ & n..... & $4,390 \quad 05$ \\
\hline 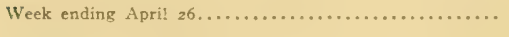 & $4,687 \geq 6$ & $\cdots \cdots \cdots$ & 4,68756 \\
\hline Fifteen days ending April $55 \ldots \ldots \ldots \ldots \ldots \ldots \ldots$ & $\cdots \cdots$ & $2,347 \quad 48$ & 2,34748 \\
\hline Fifteen days ending April $30, \ldots \ldots \ldots \ldots \ldots \ldots \ldots \ldots$ & ...... & 2,34250 & 2,342 so \\
\hline 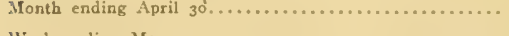 & $\cdots \cdots$ & $\cdots \cdots \cdots$ & $\cdots \cdots \cdots$ \\
\hline 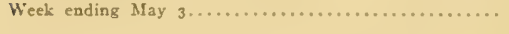 & 6,92165 & ........ & 6,93265 \\
\hline
\end{tabular}




\begin{tabular}{|c|c|c|c|}
\hline Period Ending & $\begin{array}{l}\text { Laborers, etc, } \\
\text { Weekly } \\
\text { Payroll. }\end{array}$ & $\begin{array}{l}\text { Superintendent, } \\
\text { Foremen, } \\
\text { etc., } \\
\text { Semi-Monthly } \\
\text { Payroll. }\end{array}$ & Total. \\
\hline Week ending May ro....... & 6,03140 & $\ldots \ldots \ldots$ & 6,03140 \\
\hline Week ending May $17, \ldots \ldots$. & $6,795 \quad 40$ & $\ldots \ldots \ldots$ & $6,795 \quad 40$ \\
\hline 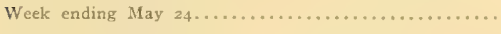 & 7,22854 & $\ldots \ldots \ldots$ & 7,22854 \\
\hline 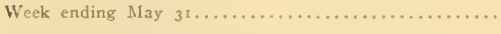 & 5,504 o5 & $\cdots \cdots \cdots$ & 5.50405 \\
\hline Fifteen days ending May $r 5 \ldots \ldots \ldots \ldots \ldots \ldots \ldots \ldots \ldots \ldots$ & $\cdots \cdots$ & $2,327 \quad 13$ & $2,327 \quad 13$ \\
\hline Sixteen days ending May 3 r...... & $\ldots \ldots$ & $2,431 \quad 25$ & $2,431 \quad 25$ \\
\hline Muntle ending Mfay $31 \ldots \ldots$. & $\ldots \ldots$ & $\ldots \ldots \ldots$ & ........ \\
\hline Week ending June $7 \ldots \ldots \ldots$. & 4,72085 & $\cdots \cdots \cdots$ & 4,72085 \\
\hline 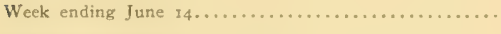 & $5,162 \quad 30$ & $\cdots \cdots \cdots$ & $5,16 z 30$ \\
\hline Week enling Iune $21 \ldots \ldots \ldots$ & 4.51249 & $\ldots \ldots$ & 4.51249 \\
\hline Werk ending June $2 \$$........ & 3.50100 & $\cdots \cdots \cdots$ & 3.59800 \\
\hline Fifteen days ending June $15 \ldots$ & $\cdots \cdots$ & 1,70500 & 1,70500 \\
\hline Fifteen days ending June $30 \ldots \ldots \ldots \ldots \ldots \ldots \ldots \ldots$ & $\cdots \cdots$ & 1,65500 & 1,65500 \\
\hline Menth entung Junce $31 \ldots \ldots$. & $\cdots \cdots$ & $\ldots \ldots \ldots$ & $\ldots \ldots \ldots$ \\
\hline Week endung Jily $5 \ldots \ldots \ldots$. & 3.52100 & $\cdots \cdots \cdots$ & 3.59100 \\
\hline Wuk ctulung July tz, . . . . . & $3,752,75$ & $\ldots \ldots \ldots$ & 3.75275 \\
\hline Eight days ending July $20 \ldots \ldots$. & $3.5 \times 3 \mathrm{I} 2$ & $\cdots \cdots \cdots$ & $3.5 \times 3 \quad 12$ \\
\hline Six days ending July $26 \ldots \ldots \ldots$ & 2,42250 & $\cdots \cdots \cdots$ & 2,42250 \\
\hline Fifteen days ending July $15 \ldots$. & $\ldots \ldots$ & $\mathrm{r}, 48_{3} \quad 7 \mathrm{r}$ & $\mathrm{r}, 4^{8} 37 \mathrm{r}$ \\
\hline Sixteen days ending July $3 \mathrm{r} . . . .$. & $\cdots \cdots$ & 1,386 of & $x, 386$ o6 \\
\hline 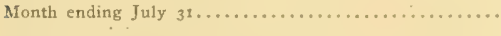 & $\cdots \cdots$ & $\cdots \cdots \cdots$ & $\cdots \cdots \cdots$ \\
\hline Week ending August $2 \ldots \ldots \ldots$. & 3,00575 & $\cdots \cdots \cdots$ & 3,00575 \\
\hline 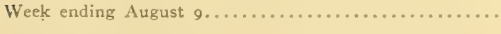 & $2,686 \quad 62$ & $\cdots \cdots \cdots$ & $2,686 \quad 62$ \\
\hline Week ending August $16 \ldots \ldots \ldots$. & 2,69537 & $\cdots \cdots \cdots$ & $2,695 \quad 37$ \\
\hline Week ending August $23 \ldots \ldots \ldots$ & 2,33637 & $\cdots \cdots \cdots$ & $2,336 \quad 37$ \\
\hline Week ending August $30 \ldots . . .$. & $2,311 \$ 5$ & n..... & 2,31255 \\
\hline Fifteen days ending August $15 \ldots \ldots \ldots \ldots \ldots \ldots \ldots \ldots$ & $\cdots \cdots$ & 1,23856 & $\mathrm{r}, 33856$ \\
\hline Sixteen days ending August $31 \ldots \ldots \ldots \ldots \ldots \ldots \ldots \ldots \ldots$ & $\cdots \cdots$ & $1,321 \quad 44$ & 1,32144 \\
\hline 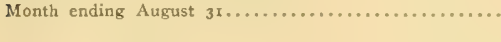 & $\cdots \cdots$ & ........ & (n...... \\
\hline Total. & . $\$ 156,04367$ & $\$ 31,077 \quad 39$ & 187,121 of \\
\hline
\end{tabular}


Payoli. Schedule No. $7 \mathrm{D}$

DEPARTMENT OF PARKS, BOROUGH OF THE BRONX.

Shorming payroll payments, January I to August 3I, I907. for serices of Superintendent, Engineers, Foremen, Laborers, ctc., charged against Budget Appropriation Account, Forestry Work:

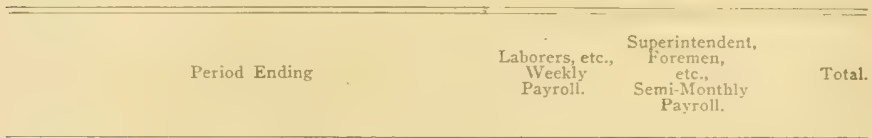

1907

Four days ending January $4 \ldots \ldots \ldots \ldots \ldots \ldots \ldots \ldots$

I89 75

$65 \quad 73$

Week ending January $18 \ldots \ldots \ldots \ldots \ldots \ldots \ldots \ldots \ldots$

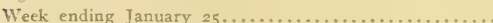

Fifteen days ending January $15 \ldots \ldots \ldots \ldots \ldots \ldots \ldots$

Sixteen days ending January $31 \ldots \ldots \ldots \ldots \ldots \ldots \ldots$

M:nuth cnding Tanuary $31 \ldots \ldots \ldots \ldots \ldots \ldots \ldots \ldots \ldots$

Week ending February

Week ending February $8, \ldots \ldots \ldots \ldots \ldots \ldots$

Week ending February r $5 \ldots \ldots \ldots \ldots \ldots \ldots \ldots \ldots \ldots$.

Week ending February $22, \ldots \ldots \ldots \ldots \ldots \ldots \ldots \ldots$

Fifteen days ending February $.55 \ldots \ldots \ldots \ldots \ldots \ldots$

Thirteen days ending February $28 \ldots \ldots \ldots \ldots \ldots \ldots$

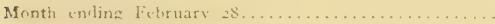

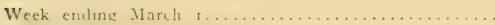

Weck unding March $8 \ldots \ldots \ldots \ldots \ldots \ldots \ldots \ldots \ldots \ldots$

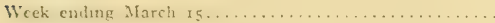

Week ending March $23 \ldots \ldots \ldots \ldots \ldots \ldots \ldots \ldots \ldots . . . \ldots \ldots$

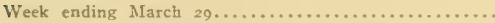

Fifteen days ending March 15

Sixteen days ending March 3

Month ending March 31 .

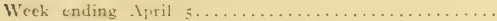

Week ending April $12 \ldots \ldots \ldots \ldots \ldots \ldots \ldots \ldots \ldots \ldots$

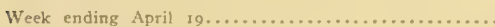

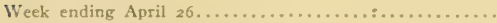

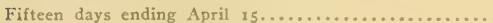

Fifteen days ending April $30 \ldots \ldots \ldots \ldots \ldots \ldots \ldots \ldots$

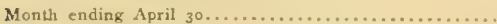

\begin{tabular}{|c|c|c|c|}
\hline$\ldots \ldots \ldots$ & & $\$ 95$ & 500 \\
\hline$\ldots \ldots \ldots$ & & 189 & 75 \\
\hline$\ldots \ldots \ldots$ & & 65 & 73 \\
\hline$\ldots \ldots$ & & 135 & 00 \\
\hline$\$ 4838$ & & 48 & 38 \\
\hline $51 \quad 62$ & & 51 & 62 \\
\hline . . . . . . . & & $\cdots \cdots$ & 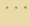 \\
\hline$\ldots \ldots \ldots$ & & I 80 & 00 \\
\hline$\ldots \ldots \ldots$ & & 142 & 50 \\
\hline$\cdots \cdots$ & & 50 & 00 \\
\hline$\ldots \ldots \ldots$ & & 54 & 00 \\
\hline $\begin{array}{ll}53 & 57\end{array}$ & $\checkmark$ & 53 & 57 \\
\hline $46 \quad 43$ & & 46 & 43 \\
\hline$\ldots \ldots \ldots$ & & & $\cdots$ \\
\hline$\ldots \ldots$ & & 60 & 00 \\
\hline$\ldots \ldots$ & & 60 & 00 \\
\hline$\ldots \ldots \ldots$ & & Es & 00 \\
\hline$\ldots \ldots \ldots$ & . & 60 & 00 \\
\hline$\ldots \ldots \ldots$ & & 60 & 00 \\
\hline $.48 \quad 38$ & & 48 & 38 \\
\hline 5262 & & 51 & 62 \\
\hline$\cdot \ldots \ldots$ & & & $\cdots$ \\
\hline$\cdots \quad \cdots$ & & 60 & 00 \\
\hline$\cdots \ldots \ldots$ & & 50 & 00 \\
\hline$\cdots \cdots$ & & 60 & 00 \\
\hline$\cdots \cdots$ & & 70 & 50 \\
\hline $50 \quad 00$ & & 50 & 00 \\
\hline $50 \quad 00$ & & 50 & 00 \\
\hline$\ldots \ldots \ldots$ & & & \\
\hline
\end{tabular}




$\begin{array}{ccc}\text { Period Ending } & \begin{array}{c}\text { Laborers, etc., } \\ \text { Weekly } \\ \text { Payroll. } \\ \text { Forementent, } \\ \text { ete., } \\ \text { Semi-Monthly. } \\ \text { Payroll. }\end{array}\end{array}$ Total.

Werk eniling May

Herke entimg Mas

Week ending May 24

Wick thiti.s May

Fiftertl doy eribus May I5

Sixteen days ending May $3 \mathrm{r}$

Month ending May 31 .

.....

$4^{5} \quad 3^{8}$

Wecte cndink Iune :-

Wecti exhling Itane $1+$.

Week ending June 21

Weck enting fune is.

Fifteen days ending June 15

Iifteen days enting Tune 30 .

Munth ending June 30

Weck enling Tuly 5

Weck ending Iuly 12

Week enting Iuly 20 .

Weck inding Iuly 20

Fifteen days ending Iuly is

Sixtecn days ending July $3 \mathrm{I}$

Munth ending July 3

Week ending August 2

Week ending August 9.

Weck ending dugust 16

Weck endug Auguit 23

Weck ending August 30 .

Fifteen days ending August 15.

Sixteen days ending August 3

Munth ending . Iugust 3 I. 
Payroll Schedule No. $8 \mathrm{~B}$.

DEPARTMENT OF PARKS, BOROUGH OF THE BRONX.

Shoucing payroll payments, January I to August 3I, 1907, for scrvices of Superintendent, Engineers, Foremen, Laborers, etc., charged against Budget Appropriation Account, Care of Trees in City Streets:

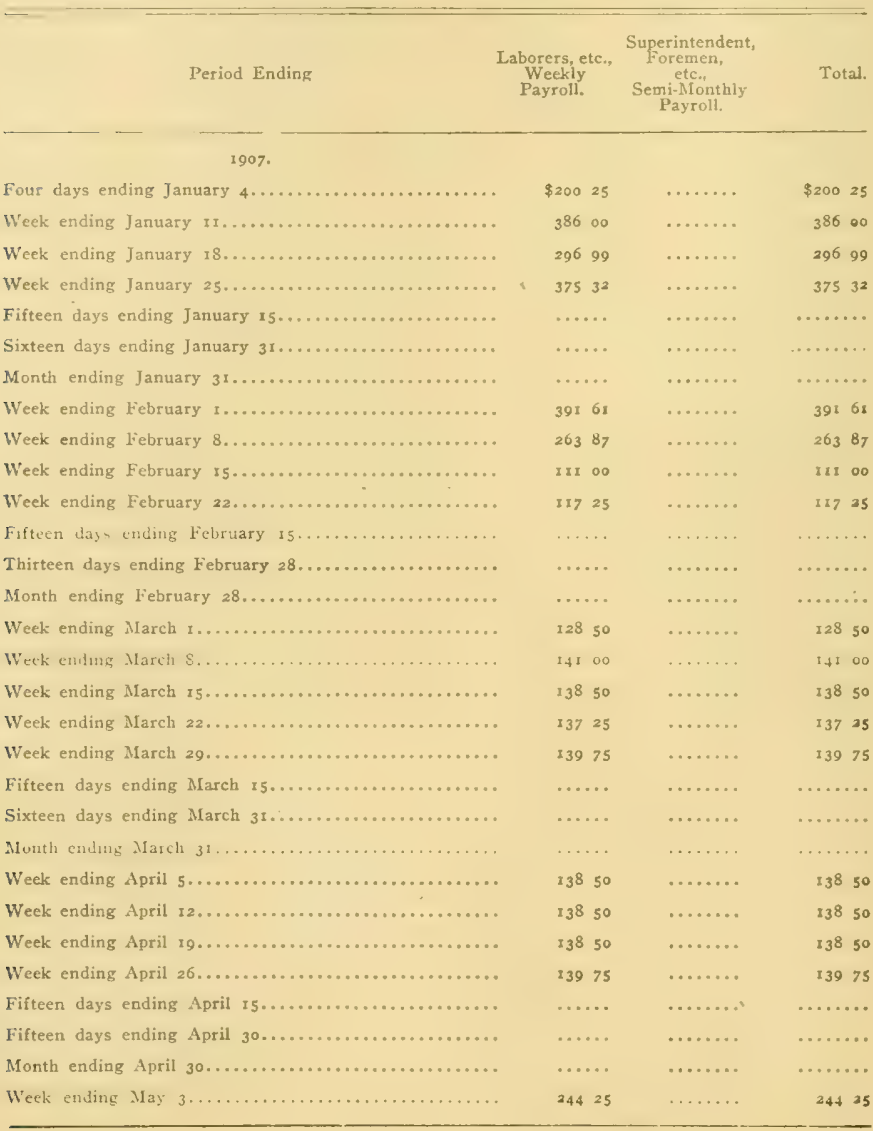




\begin{tabular}{|c|c|c|c|}
\hline Period Ending & $\begin{array}{l}\text { Laborers, etc., } \\
\text { Weekly } \\
\text { Payroll. }\end{array}$ & $\begin{array}{c}\text { Superintendent, } \\
\text { Foremen, } \\
\text { etc., } \\
\text { Semi-Minthly } \\
\text { Payroll. }\end{array}$ & Total. \\
\hline Week ending May $10 \ldots \ldots \ldots$. & $2 * 550$ & $\ldots$ & 2550 \\
\hline 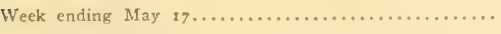 & 24300 & ….... & 24300 \\
\hline 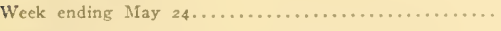 & 24175 & $\ldots \ldots \ldots$ & 24275 \\
\hline 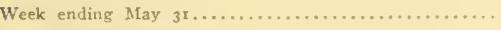 & 22350 & ........ & 22350 \\
\hline Fifteen days ending May $15, \ldots$. . & . . . . & $\ldots \ldots$ & (....... \\
\hline 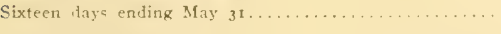 & $\cdots \cdots$ & $\ldots \ldots \ldots$ & $\therefore \quad \cdots$ \\
\hline Montb ending May 3 r............ & $\ldots$ & . . ..... & .. . . \\
\hline 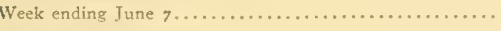 & 30425 & $\ldots \ldots \ldots$ & 30425 \\
\hline Week ending Iune $14 \ldots . . .$. . & 38425 & $\ldots \quad \cdot$ & $3^{8}+25$ \\
\hline 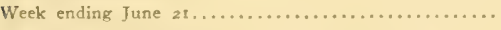 & 37950 & $\ldots \ldots \ldots$ & 37950 \\
\hline 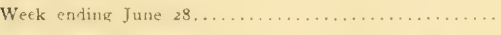 & 41450 & $\ldots \ldots \cdots$ & 41450 \\
\hline 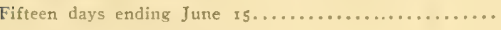 & ....... & $\$ 5000$ & 5000 \\
\hline Fifteen days ending June $30 \ldots \ldots \ldots \ldots \ldots \ldots \ldots \ldots$ & $\ldots \ldots$ & 5000 & 5000 \\
\hline 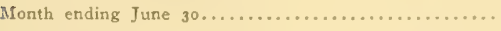 & ....... & ......... & ........ \\
\hline 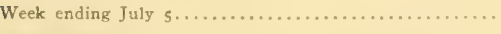 & 35962 & $\therefore \cdots \cdots$ & 35962 \\
\hline Week ending July $12 \ldots . \ldots$. & $4+1$ ș. & $\ldots \ldots \ldots$ & $4+150$ \\
\hline Week ending July $20 . \ldots \ldots \ldots$. & $7274_{12}$ & $\ldots \ldots$ & $\because 2762$ \\
\hline Week enting July $25 \ldots \ldots \ldots \ldots \ldots$ & 529511 & $\cdots \cdots$ & 52. 50 \\
\hline Fifteen days ending July $15 \ldots \ldots \ldots \ldots \ldots \ldots \ldots \ldots$ & $\cdots \cdots$ & $4^{8} 3^{8}$ & $483^{8}$ \\
\hline Sixteen days ending July $3 t \ldots \ldots \ldots \ldots \ldots \ldots \ldots \ldots$ & ....... & I16 10 & 11610 \\
\hline 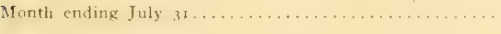 & $\ldots \ldots$ & $\cdots \cdots \cdots$ & $\cdots \cdots \cdots$ \\
\hline Week ending August $2 \ldots \ldots \ldots \ldots \ldots \ldots \ldots \ldots \ldots \ldots \ldots \ldots$ & 60375 & $\cdots \cdots \cdots$ & 60375 \\
\hline Week ending August $9 \ldots \ldots \ldots \ldots \ldots \ldots \ldots \ldots \ldots \ldots \ldots$ & 62600 & $\cdots \cdots \cdots$ & 62600 \\
\hline 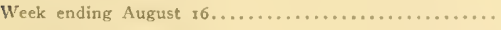 & 59675 & ........ & 59675 \\
\hline 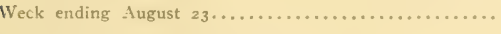 & 64075 & ........ & 64075 \\
\hline 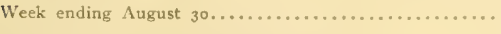 & 61950 & $\cdots \cdots \cdots$ & 61950 \\
\hline Fifteen days ending August $15 \ldots \ldots \ldots \ldots \ldots \ldots \ldots \ldots \ldots$ & ...... & 10886 & 10886 \\
\hline Sixteen days ending August $3 x \ldots \ldots \ldots \ldots \ldots \ldots \ldots$ & …. & II 614 & 11614 \\
\hline \multirow[t]{2}{*}{ 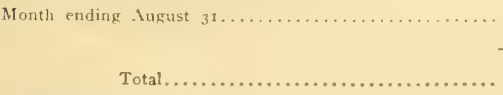 } & $\cdots \cdots$ & $\cdots \cdots \cdots$ & $\cdots+\cdots$ \\
\hline & $\$ x x, 168$ o3 & $\$ 48948$ & $\$ 11,65751$ \\
\hline
\end{tabular}


Payroll Schiedule No. 9 B.

\section{DEPARTIENT OF PARKS, BOROUGH OF THE BRONX.}

Shoung payroll payments, Jamury I to August 3I, 190\%, for scrices of Superintendent, Engincers, Foremen, Laborers, etc., charged against Corporate Stock Appropriations authorized for the construction and improvement of parks. parkways, boulezards, driz'es, ctc.:

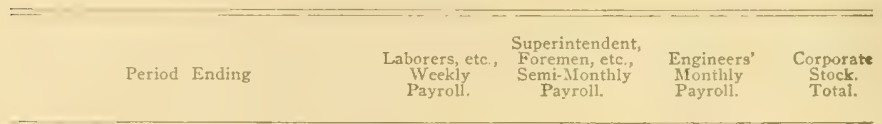

J96\%.

Week ending January 4

Week ending January $17 \ldots \ldots \ldots \ldots \ldots$

Weck ending January $18 \ldots . \ldots \ldots \ldots \ldots$

Muh sndme Tanury $=5 \ldots \ldots \ldots \ldots \ldots$

Fifteen days ending January $15 \ldots \ldots \ldots$.

Sixteen days ending January $31 \ldots . . .$.

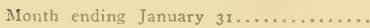

Weck ending February I..............

Week ending February $8 \ldots \ldots \ldots \ldots \ldots \ldots$

Week ending February $15 \ldots \ldots \ldots \ldots \ldots$.

Week ending February $22 \ldots \ldots \ldots \ldots \ldots$.

Fifteen days ending February $15 \ldots \ldots \ldots$.

Thirteen days ending February $28 \ldots \ldots$.

Month ending February $28 \ldots \ldots \ldots \ldots \ldots$

Week ending March $1 \ldots \ldots \ldots \ldots \ldots \ldots .$.

Weck ending March $8 \ldots \ldots \ldots \ldots \ldots \ldots$

Week ending March $15 \ldots \ldots \ldots \ldots \ldots \ldots$

Week ending March $22 \ldots \ldots \ldots \ldots \ldots \ldots$.

Week ending March $29 . \ldots \ldots \ldots \ldots \ldots$.

Fifteen days ending March $15 \ldots . . .$.

Sixteen days ending March $3 \mathrm{r} \ldots \ldots \ldots \ldots$

Month ending March $32 \ldots . . \ldots \ldots \ldots$

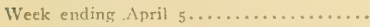

Week ending April $12 \ldots \ldots \ldots \ldots \ldots \ldots$.

Week ending April $19 . \ldots \ldots \ldots \ldots \ldots$.

Week ending April 26 .

Fifteen days ending April $15 \ldots \ldots \ldots .$.

Fifteen days ending April $30 . \ldots \ldots \ldots \ldots$

Month ending April $30 . . . . . . . . . .$.

\begin{tabular}{|c|c|c|c|c|}
\hline$\$ 1,343$ & 50 & $\ldots \ldots$ & $\ldots \ldots$ & $\$ 1,343$ \\
\hline 2,217 & 37 & $\ldots \ldots$ & $\ldots \ldots$ & 2,217 \\
\hline $1,39^{\circ}$ & 05 & $\ldots \ldots$ & $\ldots \ldots$ & 1,390 \\
\hline I. $S_{3 I}$ & $G_{2}$ & $\ldots \ldots$ & $\ldots \ldots$ & $1.8,31$ \\
\hline$\ldots \ldots$ & $\cdots$ & $\$ 447 \quad 52$ & $\ldots \ldots$ & 447 \\
\hline$\ldots \ldots$ & .. & 47748 & $\ldots \ldots$ & 477 \\
\hline$\ldots \ldots$ & $\cdots$ & $\ldots \ldots$ & $-\$ 29355$ & 293 \\
\hline 1,585 & 24 & $\ldots \ldots$ & $\ldots \ldots$ & $x, 585$ \\
\hline 858 & 87 & $\ldots \ldots$ & $\ldots \ldots$ & 858 \\
\hline 605 & I8 & $\ldots \ldots$ & $\ldots \ldots$ & 605 \\
\hline 338 & 50 & $\cdots \cdots$ & $\ldots \ldots$ & $33^{8}$ \\
\hline$\ldots \ldots$ & $\cdots$ & 44195 & $\ldots \ldots$ & 441 \\
\hline$\cdots \cdots$ & $\cdots$ & 24376 & $\ldots \ldots$ & 243 \\
\hline$\ldots \ldots$ & $\cdots$ & $\ldots \ldots$ & 30000 & 300 \\
\hline 422 & 94 & $\ldots \ldots$ & $\cdots \cdots$ & 422 \\
\hline 283 & $2 \mathrm{I}$ & $\ldots \ldots$ & $\ldots \ldots$ & 283 \\
\hline 253 & 30 & $\ldots \ldots$ & $\ldots \ldots$ & 253 \\
\hline 253 & 30 & $\ldots \ldots$ & $\ldots \ldots$ & 253 \\
\hline 94 & Do & $\ldots \ldots$ & $\ldots \ldots$ & 94 \\
\hline$\ldots \ldots$ & $\cdots$ & 15724 & $\ldots \ldots$ & $\times 57$ \\
\hline$\ldots \ldots$ & $\cdots$ & 13537 & $\ldots \ldots$ & 135 \\
\hline$\ldots \ldots$ & $\cdots$ & $\ldots \ldots$ & 30000 & 300 \\
\hline 90 & 50 & $\ldots \ldots$ &,$\ldots \ldots$ & 90 \\
\hline 88 & 50 & $\ldots \ldots$ & $\ldots \ldots$ & 88 \\
\hline 76 & 50 & $\ldots \ldots$ & $\ldots \ldots$ & 76 \\
\hline 166 & 50 & $\cdots \ldots$ & $\cdots \ldots$ & 166 \\
\hline$\ldots \ldots$ & $\cdots$ & $50 \quad 00$ & $\ldots \ldots$ & 50 \\
\hline$\ldots \ldots$ & $\cdots$ & 5000 & $\cdots$ & 50 \\
\hline$\ldots$. & $\cdots$ & $\ldots \ldots$ & $256 \quad 67$ & 256 \\
\hline
\end{tabular}




\begin{tabular}{|c|c|c|c|c|c|}
\hline Period Ending & $\begin{array}{l}\text { Laborers, etc., } \\
\text { Weekly } \\
\text { Payroll. }\end{array}$ & $\begin{array}{l}\text { Superintendent, } \\
\text { Foremen, etc., } \\
\text { Semi-Monthly } \\
\text { Payroll. }\end{array}$ & $\begin{array}{l}\text { Engineers' } \\
\text { Monthly } \\
\text { Payroll. }\end{array}$ & $\begin{array}{c}\text { Corporate } \\
\text { Stock. } \\
\text { Total. }\end{array}$ & ate \\
\hline Week ending May $3 \ldots \ldots \ldots \ldots \ldots \ldots$ & $123 \quad 04$ & $\ldots \ldots$ & $\cdots \cdots$ & 12304 & \\
\hline 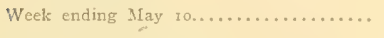 & 20100 & $\cdots \cdots$ & $\cdots \cdots$ & 20100 & $\infty$ \\
\hline Week ending May $17 . \ldots \ldots \ldots \ldots \ldots \ldots$ & 22425 & $\cdots \cdots$ & $\cdots \cdots$ & 22425 & 25 \\
\hline Week ending May $24 \ldots \ldots \ldots \ldots \ldots \ldots . . . .$. & 32975 & $\cdots \cdots$ & $\cdots \cdots$ & 32975 & 75 \\
\hline Week ending May $31 . . . \ldots \ldots \ldots \ldots \ldots . . . .$. & 1,79325 & $\cdots \cdots$ & $\cdots \cdots$ & 1.79325 & 25 \\
\hline Fifteen day ending May $15 \ldots \ldots \ldots \ldots$. & $\cdots \cdots \cdots$ & 6048 & ..... & 6049 & 48 \\
\hline Sixteen days ending May 3 I............. & $\cdots \cdots \cdots$ & $116 \times 4$ & - w. & 11614 & 14 \\
\hline Month endirg May $3 x \ldots \ldots \ldots \ldots \ldots \ldots$ & $\cdots \cdots \cdots$ & $\cdots \cdots$ & $I_{51} \quad 62$ & 1566 & 62 \\
\hline Week ending June $7 \ldots \ldots \ldots \ldots \ldots \ldots$ & 1,84321 & $\cdots \cdots$ & $\cdots \cdots$ & $1,8+3 x+$ & 21 \\
\hline Week ending June r $4 \ldots \ldots \ldots \ldots \ldots \ldots$ & $2,44^{2} 29$ & $\cdots \cdots$ & $\cdots \cdots$ & 2,44228 & 20 \\
\hline 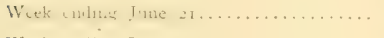 & $212-5<3$ & … & $\cdots \cdots$ & $2, y+5,25$ & 23 \\
\hline Week ending June $28 \ldots \ldots \ldots \ldots \ldots \ldots$ & $4,074 G_{5}$ & $\cdots \cdots$ & $\cdots \cdots$ & $4,074,6$ & 65 . \\
\hline Fifteen days ending June $15 \ldots \ldots \ldots \ldots$ & $\cdots \cdots \cdots$ & 76250 & $\cdots \cdots$ & 7625 & 50 \\
\hline lifteen days ending June $30 \ldots \ldots \ldots \ldots$ & $\cdots \cdots \cdots$ & 81250 & $\cdots \cdots$ & 8125 & 50 \\
\hline Month ending Tune $30 \ldots \ldots \ldots \ldots \ldots . . .$. & $\cdots \cdots+$ & $\cdots \cdots$ & 55750 & 5575 & 50 \\
\hline Week ending July $5, \ldots \ldots \ldots \ldots \ldots \ldots$ & 3,16870 & $\cdots \cdots$ & $\cdots \cdots$ & 3,1687 & 70 \\
\hline Week ending July $12 \ldots \ldots \ldots \ldots \ldots \ldots$ & $3.840 \quad 40$ & $\cdots \cdots$ & $\cdots \cdots$ & 3,8404 & 40 \\
\hline Week ending July $20 \ldots \ldots \ldots \ldots \ldots \ldots$ & 5,00884 & $\cdots \cdots$ & $\cdots \cdots$ & 5,0088 & 84 \\
\hline Week ending July $26 \ldots \ldots \ldots \ldots \ldots \ldots$ & $4,026 \quad 37$ & …. & - $\cdots$ & 4,0263 & 37 \\
\hline Fifteen days ending July $55 \ldots \ldots \ldots \ldots \ldots$ & $\cdots \cdots \cdots$ & 90390 & $\cdots \cdots$ & 9039 & 90 \\
\hline Sixteen days ending July $3 x \ldots \ldots \ldots \ldots$ & $\cdots \cdots \cdots$ & $\$, 07100$ & $\cdots \cdots$ &, $\pm 071 \circ$ & $\infty$ \\
\hline Month ending July $31, \ldots \ldots \ldots \ldots \ldots$. & $\cdots \cdots \cdots$ & $\cdots \cdots$ & 55750 & 5575 & 50 \\
\hline Week ending August $2 \ldots \ldots \ldots \ldots \ldots \ldots$ & 4,60880 & $\cdots \cdots$ & $\cdots \cdots$ & 4,6088 & So \\
\hline Week ending August $9 \ldots \ldots \ldots \ldots . . .$. & $4,89 \times 28$ & $\cdots \cdots$ & … & $4.891=$ & 28 \\
\hline Week ending August $r 6 \ldots \ldots \ldots \ldots \ldots$ & 5.52975 & $\cdots \cdots$ & $\cdots \cdots$ & 5.5297 & 75 \\
\hline Week ending - Iugust $23 \ldots \ldots \ldots \ldots \ldots$. & $5,843 \quad 49$ & $\cdots \cdots$ & $\cdots \cdots$ & 5.8 .43 & 49 \\
\hline Week ending August $30 \ldots \ldots \ldots \ldots \ldots$ & $5.67 \times 58$ & $\cdots \cdots$ & $\cdots \cdots$ & 5,671 & 58 \\
\hline Fifteen days ending August $15 \ldots \ldots \ldots$. & $\cdots \cdots \cdots$ & $1,088 ' 57$ & $\cdots \cdots$ & 1,088 & 57 \\
\hline Sixtcen days ending August $3 x \ldots \ldots \ldots$. & $\cdots \cdots \cdots$ & 1,16143 & $\cdots \cdots$ & $x, 161$ & 43 \\
\hline Montli ending August $32 \ldots \ldots \ldots \ldots \ldots$ & $\cdots \cdots \cdots$ & $\cdots \cdots$ & 55121 & 551 & $2 \mathrm{I}$ \\
\hline Total...................... & $\$ 08,44496$ & $\$ 7,97984$ & $\$ 2,968$ os & $\$ 79.392$ & 85 \\
\hline
\end{tabular}


Payroll Schedule No. ioB.

DEPARTMENT OF PARKS, BOROUGH OF THE BRONX.

Summary showing payroll payments, January I to August 31, 1907, for services of Superintendent, Enginecrs, Foremen, Laborers, etc., charged against Budget Appropriations and Corporate Stock Accounts:

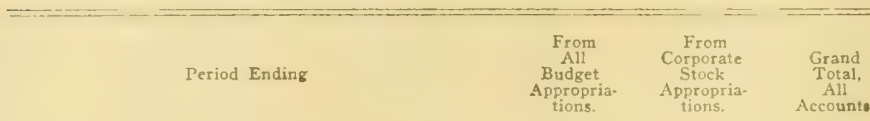

1907.

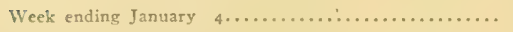

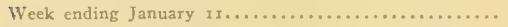

$\$ 4,37543$

8,46388

$6,173 \quad 03$

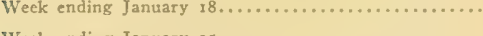

-

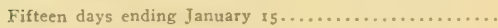

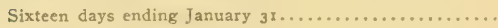

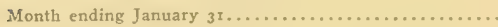

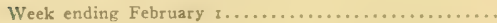

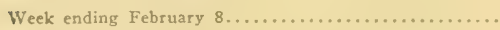

Week ending February $15 \ldots \ldots \ldots \ldots \ldots \ldots \ldots \ldots \ldots . . . \ldots \ldots$

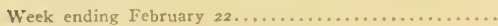

Fifteen days ending February $55 \ldots \ldots \ldots \ldots \ldots \ldots \ldots$

Thirteen days ending February $38 \ldots \ldots \ldots \ldots \ldots \ldots \ldots$

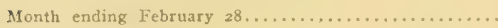

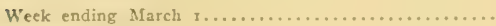

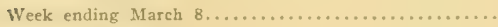

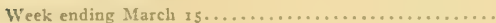

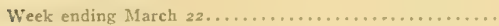

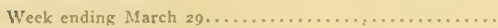

Fifteen days ending Mareh $15, \ldots \ldots \ldots \ldots \ldots \ldots \ldots$,

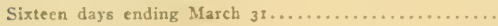

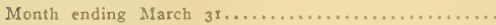

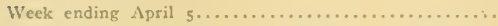

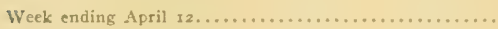

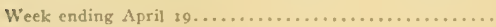

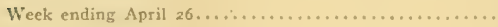

Fifteen days ending April $15 \ldots \ldots \ldots \ldots \ldots \ldots \ldots \ldots \ldots$

Fifteen days ending April $30 \ldots \ldots \ldots \ldots \ldots \ldots \ldots \ldots$

$\begin{array}{rrrr}\$ 1,343 & 50 & \$ 5,718 & 93 \\ 1,217 & 37 & 10,681 & 25 \\ 1,390 & 05 & 7,563 & 08 \\ 1,831 & 62 & 6,935 & 06 \\ 447 & 52 & 2,508 & 46 \\ 477 & 48 & 2,705 & 47 \\ 293 & 55 & 293 & 55 \\ 1,585 & 24 & 10,724 & 34 \\ 858 & 87 & 7,231 & 49 \\ 605 & 18 & 3,787 & 64 \\ 338 & 50 & 3,763 & 77 \\ 441 & 95 & 2,694 & 50 \\ 243 & 76 & 2,221 & 74 \\ 300 & 00 & 300 & 00 \\ 422 & 94 & 4,549 & 19 \\ 283 & 21 & 4,013 & 89 \\ 253 & 30 & 4,058 & 82 \\ 253 & 30 & 4,067 & 94 \\ 94 & 00 & 4,467 & 49 \\ 157 & 24 & 2,390 & 83 \\ 135 & 37 & 2,521 & 58 \\ 300 & 00 & 300 & 00 \\ 90 & 50 & 4,324 & 50 \\ 88 & 30 & 4,378 & 75 \\ 76 & 50 & 4,665 & 05 \\ 166 & 50 & 5,063 & 91 \\ 50 & 00 & 2,447 & 48 \\ 50 & 00 & 2,442 & 50\end{array}$




\begin{tabular}{cccc} 
From & From \\
Period Ending & $\begin{array}{c}\text { All } \\
\text { Corporate } \\
\text { Stock } \\
\text { Appropria. } \\
\text { tions. }\end{array}$ & $\begin{array}{c}\text { Appropria- } \\
\text { tions. }\end{array}$ & $\begin{array}{c}\text { Total } \\
\text { All } \\
\text { All }\end{array}$ \\
\hline
\end{tabular}

1907.

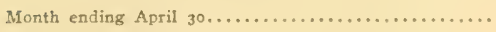

\begin{tabular}{|c|c|c|c|c|c|}
\hline$\ldots \ldots$ & $\cdots$ & 256 & 67 & 256 & 67 \\
\hline 7,301 & 90 & 123 & 04 & 7.424 & 94 \\
\hline 6,337 & 90 & 201 & oo & $6.53^{8}$ & 90 \\
\hline 7,158 & 40 & 224 & 25 & $7 \cdot 382$ & 65 \\
\hline $7,590=$ & 29 & 329 & 75 & 7,020 & 04 \\
\hline 5.7275 & 55 & 1,793 & 25 & 7,520 & 80 \\
\hline 2,375 & $5 I$ & 60 & 48 & 2,435 & 99 \\
\hline 2,4828 & 87 & 116 & $\mathrm{I}_{4}$ & 2,599 & or \\
\hline$\ldots \ldots$ & $\cdots$ & I5I & 62 & $15 I$ & 62 \\
\hline 5,025 & 10 & $x, 843$ & $2 \mathrm{I}$ & 6,868 & 31 \\
\hline 5,5465 & 55 & 2,442 & 29 & 7,988 & 84 \\
\hline 4,8919 & 99 & 2,925 & 23 & 7,817 & 22 \\
\hline 4,005 & so & 4,074 & 65 & 8,080 & IS \\
\hline$t, 755$ & 00 & 762 & 50 & 2,517 & 50 \\
\hline 1,705 & 00 & 812 & 50 & 2,517 & 50 \\
\hline$\cdots \cdots$ & $\cdots$ & 557 & 50 & 557 & 50 \\
\hline 3.950 & 62 & $3, \pm \in 8$ & 70 & 7.741 & 32 \\
\hline $4,194=$ & 25 & 3,840 & 40 & 8.012 & 65 \\
\hline $4,240 ?$ & 74 & 5,008 & 84 & 9,249 & $5^{8}$ \\
\hline 2,952 & 00 & 4,026 & 37 & 6,978 & 37 \\
\hline 1,532 & 09 & 903 & 90 & 2,435 & 90 \\
\hline$x, 502$ & 16 & $I, 07 I$ & oo & 2,573 & 16 \\
\hline$\cdots \cdots$ & $\cdots$ & 557 & 50 & $\$ 57$ & 50 \\
\hline 3,6095 & 50 & 4,608 & So & 8,218 & 30 \\
\hline 3,312 & 62 & $4.89 r$ & 28 & 8,203 & 90 \\
\hline 3,292 & 12 & 5.529 & 75 & 8,821 & 87 \\
\hline 2,977 & 12 & 5,843 & 49 & 8,820 & $6 t$ \\
\hline 2,931 & 05 & $5,67 x$ & 58 & 8,602 & 63 \\
\hline$I, 3474$ & 42 & $x, 0 S S$ & 57 & 2,435 & 99 \\
\hline 1,437 & 58 & $x, 16 x$ & 43 & 2,599 & or \\
\hline$\ldots \ldots$ & $\cdots$ & $55 \mathrm{I}$ & 21 & $55^{I}$ & 21 \\
\hline- & - & - & - & & \\
\hline $1,20 \mathrm{~S}$ & 05 & $\$ 79,392$ & $8_{5}$ & 80,600 & 90 \\
\hline
\end{tabular}

Week ending May 3

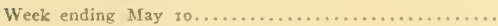

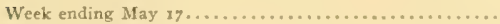

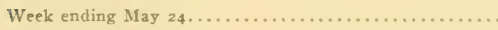

Week ending May 3 r. . .

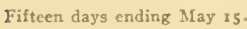

Sixteen days ending May $3 \mathrm{z}$....

Month ending May $3 x$

Week ending June 7

Week ending June $t_{4}$

Week ending June 21

Week ending June 28 ...

Fifteen days ending June 15

Vifteen days ending June 30.

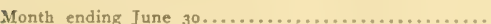

Week ending july $5, \ldots \ldots \ldots \ldots \ldots \ldots \ldots \ldots \ldots$

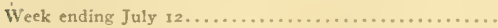

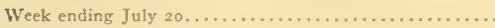

Week ending July 26

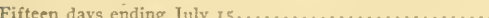

Sixteen days ending July $31 \ldots \ldots \ldots \ldots \ldots \ldots \ldots \ldots$

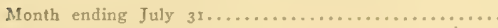

Week ending August 2

Week ending August 9

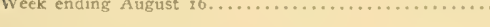

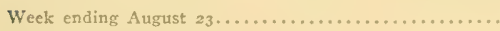

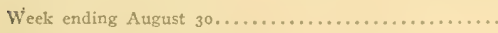

Fifteen days ending August $15 \ldots \ldots \ldots \ldots \ldots \ldots \ldots$

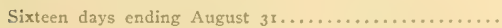

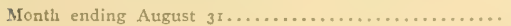


PAykoll. Schedule No. IIB.

DEPARTMENT OF PARKS, BOROUGH OF THE BRONX.

- Statement shoaring payroll paynents during Igo6 for hired teans, horses and carts from Budget Appropriation Account, Maintenance and Construction:

\begin{tabular}{|c|c|c|c|c|}
\hline Period Ending. & $\begin{array}{l}\text { Horses } \\
\text { and Carts. }\end{array}$ & Teams. & Total. & \\
\hline & & & & \\
\hline trive days ending January $5 \ldots \ldots \ldots \ldots \ldots \ldots \ldots \ldots \ldots \ldots \ldots$ & $\$ 30000$ & $\$ 486$ o0 & $\$ 786$ oo & \\
\hline Week ending January $x 2 \ldots \ldots \ldots \ldots \ldots \ldots \ldots \ldots \ldots \ldots \ldots \ldots \ldots$ & 43650 & 71325 & 1,14975 & 75 \\
\hline Week ending January $19 \ldots \ldots \ldots \ldots \ldots$. & $\cdots \cdots \cdots$ & ….... & …... & \\
\hline 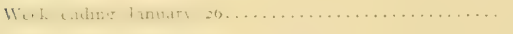 & 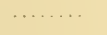 & $\ldots \ldots \ldots$ & $\cdots \cdots$ & . \\
\hline Week ending February $2, \ldots \ldots \ldots \ldots \ldots \ldots \ldots \ldots \ldots \ldots \ldots \ldots$ & I6 50 & $I_{3} 50$ & $30 \mathrm{oc}$ & $\infty$ \\
\hline Week ending Eebruary $9 \ldots \ldots \ldots \ldots \ldots \ldots \ldots \ldots \ldots \ldots \ldots \ldots$ & 450 & 1350 & 18 or & oo \\
\hline Week ending February $16 \ldots \ldots \ldots \ldots \ldots \ldots \ldots \ldots \ldots \ldots \ldots \ldots$ & $\cdots \cdots \cdots$ & 2700 & a) 0 & 00 \\
\hline Week ending February $23 \ldots$. & 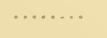 & 2700 & 2700 & $\infty$ \\
\hline Week ending March $2 \ldots \ldots \ldots \ldots \ldots \ldots \ldots \ldots \ldots \ldots \ldots \ldots \ldots \ldots \ldots \ldots \ldots$ & $\cdots \cdots+$ & 2700 & 27 oc & oo \\
\hline Week ending March $9 . . . .$. . & $\ldots \ldots \ldots$ & 2475 & 2475 & 75 \\
\hline Week ending Warch $16 \ldots . .$. & 2400 & 2700 & 51 or & $\infty 0$ \\
\hline Week ending March $23 \ldots . .$. & 1500 & 2700 & 420 & 00 \\
\hline Week ending March $30 \ldots . .$. & 28 ool & 2700 & 45 or & 00 \\
\hline Week endirg April 6....... & 1800 & 3700 & 45 or & 00 \\
\hline 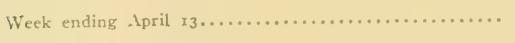 & 4874 & $1676 t$ & 2163 & 35 \\
\hline 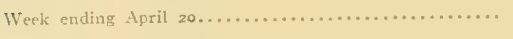 & 9000 & 24300 & $333 \circ$ & 00 \\
\hline 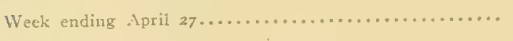 & 9975 & 30371 & 4034 & 46 \\
\hline Week ending Miay 4 . . . . . . . . . . . . . . . . . . . . . . . & 27375 & 67624 & 9499 & 99 \\
\hline 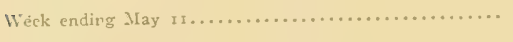 & .27262 & 52922 & 8018 & 84 \\
\hline Week ending May $18 . . . \ldots \ldots \ldots$ & $2 \% 000$ & $640 \quad 12$ & 9101 & 12 \\
\hline Week ending May $25 \ldots \ldots \ldots \ldots$. & 14400 & 59175 & 7357 & 75 \\
\hline Week ending June $1 \ldots \ldots \ldots \ldots$. & 16049 & 58048 & 7408 & 87 \\
\hline 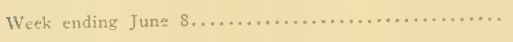 & 23600 & $78_{3} 00$ & 999 o & 00 \\
\hline 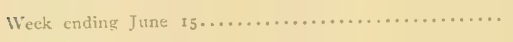 & 21300 & 79425 & 5.0072 & 25 \\
\hline 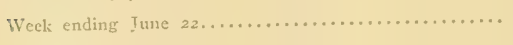 & 16874 & 599 10 & 7678 & 84 \\
\hline 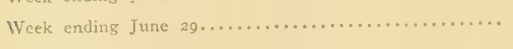 & 36400 & 83925 & 3,1032 & 25 \\
\hline Week ending July $6 \ldots \ldots \ldots \ldots \ldots$ & 6000 & 40500 & 4650 & oo \\
\hline Week ending Iuly $13 \ldots \ldots$ & 7050 & 46800 & $53^{8} 5$ & 50 \\
\hline Week ending July $20 \ldots \ldots$. & $936 I$ & $461 \times 7$ & 5597 & -8 \\
\hline Weck ending July $27 \ldots$. . & 6824 & $435 \quad 33$ & $503=$ & 57 \\
\hline Weck ending August $3 \ldots$ & 6000 & 36225 & 422 & 25 \\
\hline 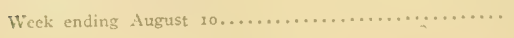 & 7200 & 47250 & $5+4=$ & +50 \\
\hline
\end{tabular}


65

\section{Period Ending}

Horses

Teams.

Total.

1906

Week ending August 17.

Week ending August 24 .

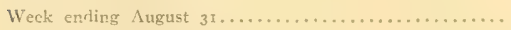

Week ending September

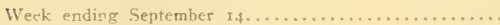

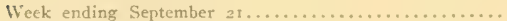

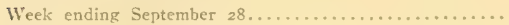

Week ending October 5

Week ending October r $2 \ldots \ldots \ldots \ldots \ldots \ldots \ldots \ldots \ldots \ldots$

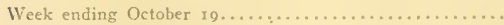

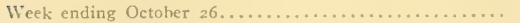

Week ending November $2, \ldots \ldots \ldots \ldots \ldots \ldots \ldots \ldots \ldots$

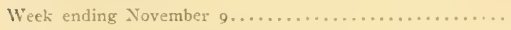

Week ending November $16 \ldots \ldots \ldots \ldots \ldots \ldots \ldots \ldots . . . \ldots \ldots$

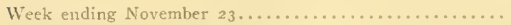

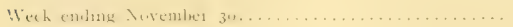

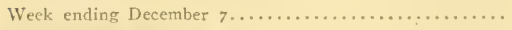

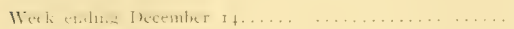

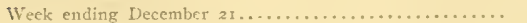

Ten days, ending December $3 r \ldots \ldots \ldots \ldots \ldots \ldots \ldots \ldots$

\begin{tabular}{rrr}
7825 & 15754 & 23579 \\
24612 & 32872 & 57484 \\
\cline { 4 - 4 } & $\$ 14.9 \$ 37$ & $\$ 19,49012$
\end{tabular}

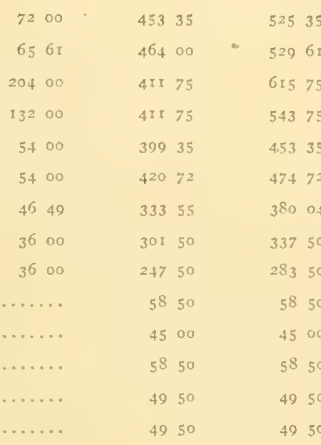


PAYRoll Schedtle No. $12 B$

DEPARTIENT OF PARKS, BOROUGH OF THE BRONX.

Statencut shoteing payroll payments during 1906 for hircd tcams, horses and carts from Budget Appropriation Account, Forestry IIork, ctc.:

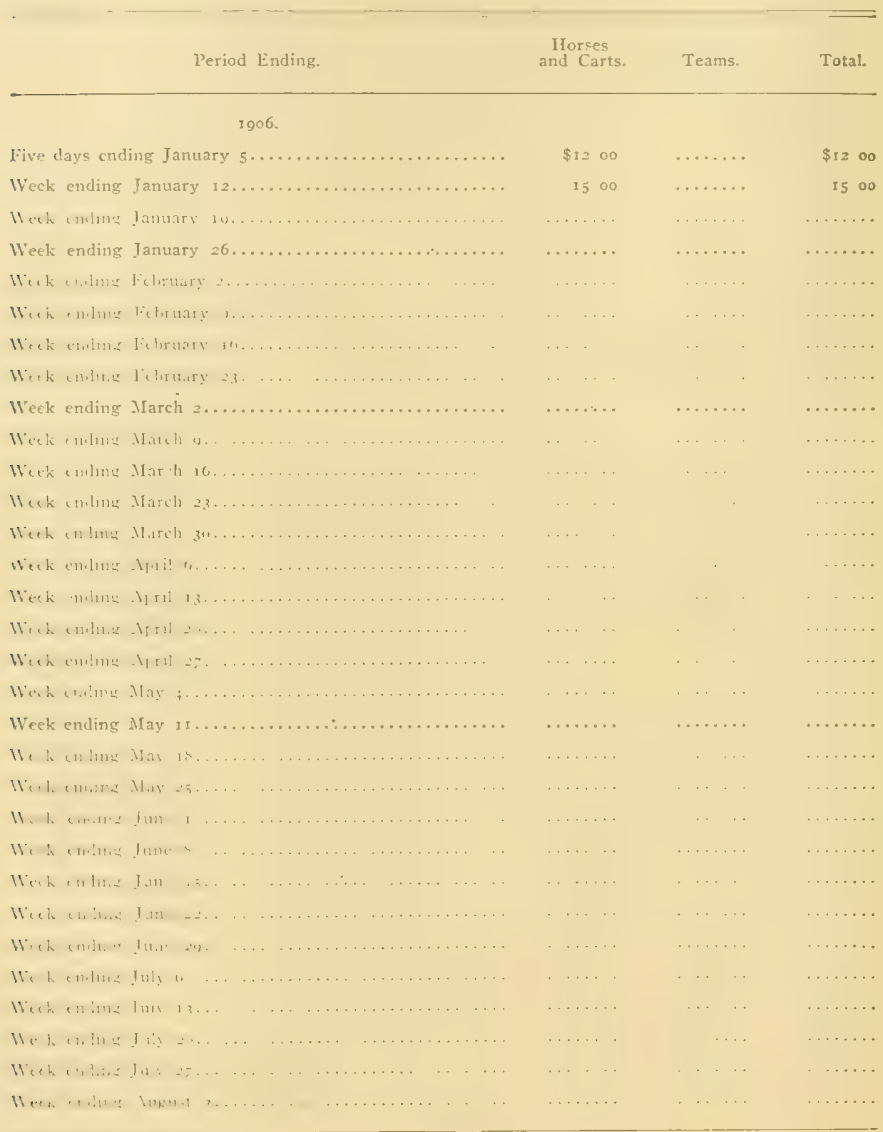




\section{7}

Period Ending.

1906.

Week cndimg Atuguat In.

Waek ending August 17.

Week ending August 24

Weck endrag August $3 \mathrm{I}$.

Wieck ending seritember

Weck ending September $r$

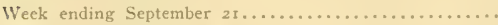

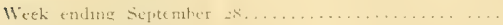

Week indmu o bet sher 5 . .

Wick ewling (ktulur 1

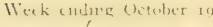

lleek ening Get its $\mathrm{r}$ : 0

Week euding November

Weck ending November 9

Week nnding November 16

Wetk ending November 2.3

Week ending November $30 \ldots$

Werk ending December 7

Week ending Necember 14 ..

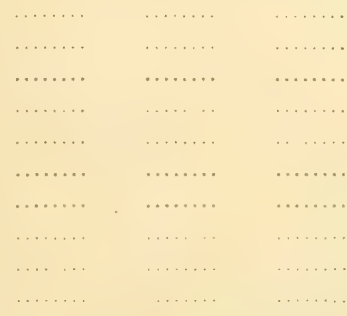

Wieh cuilute lecember 21 .

Iend das endeng thecriber 31 .

Total. 
Pajroll Schedule No. i3B.

DEPARTAENT OF PARKS, BOROUGH OF THE BRONX.

Scheduls of payroll payments during Igc6 for hircd teams, horses and carts from Special Rerenue Bond Fund, to meet deficiencics in Budget Appropriation Accont:

Period Ending.

1906.

I 116 days endune Jamuary 5 .

Wich. whin:e Jamuary

Wich andine Tamuary io.

Week ending January 26

Week cuting Fetruary $=\ldots \ldots \ldots \ldots \ldots \ldots \ldots \ldots \ldots$

Wech collink fehruary $0 \ldots \ldots \ldots \ldots \ldots \ldots \ldots \ldots \ldots$

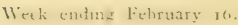

Wiek unlme Fithuary 2,3

Week unling Mareh 2.

Week ending March 9

Weak enslung Warkh t6.

Wuk emline March :3.

Wiek eming Warch 3

Ileek uning ipril o.

Week ending April I 3

Week culius ipril an.

Wut cmluth Ifril z-

Werk chliug May + .

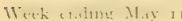

Ween emlung Mhy ts

Week ending May 25

Wiels anlue lane

Wiech it dine imu is

Week ending June 15

Wuk a onlan at ! un:

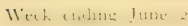

Week ending July 6

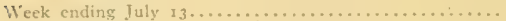

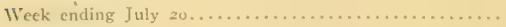

Week ending Iuly 27

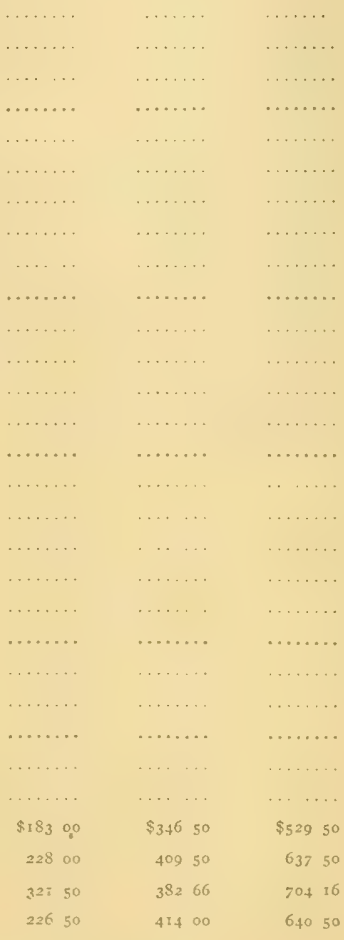




Ilorses
Period Ending. $\quad$ Carts. Teams. Total.

1906

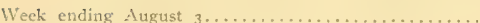

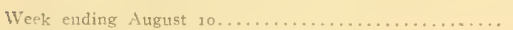

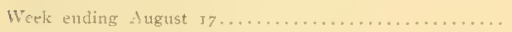

$\begin{array}{lll}17625 & 32373 & 49068 \\ 20400 & 40275 & 60675 \\ 21600 & 39487 & 61087 \\ 20847 & 39316 & 60163 \\ 20400 & 41175 & 61575 \\ 16125 & 37350 & 53475 \\ 16500 & 34650 & 51150 \\ 17500 & 31500 & 49000 \\ 13575 & 22611 & 36186 \\ 9900 & 20925 & 30825 \\ 7200 & 13050 & 20250 \\ 5100 & 19800 & 24900 \\ 4500 & 15975 & 20475 \\ 5175 & 19911 & 25086 \\ 5400 & 17100 & 22500 \\ 1.0 & .12 & 2\end{array}$

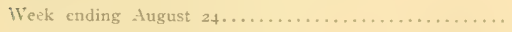

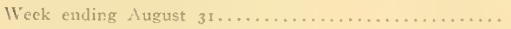

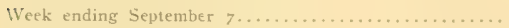

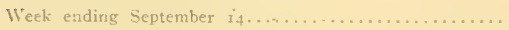

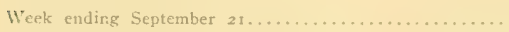

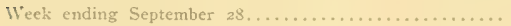

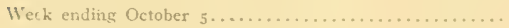

Week erding October rz, .....................

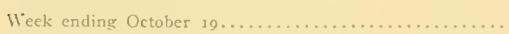

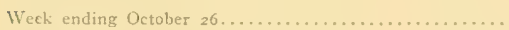

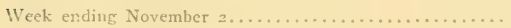

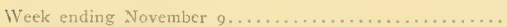

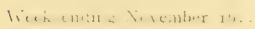

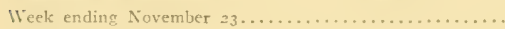

$\begin{array}{lll}\ldots \ldots \ldots & 2700 & 2700 \\ \ldots \ldots \ldots & 2700 & 2700\end{array}$

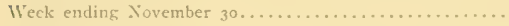

$\begin{array}{lll}5731 & 2025 \quad 7756\end{array}$

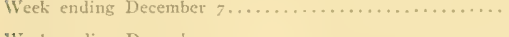

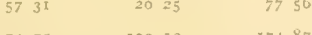

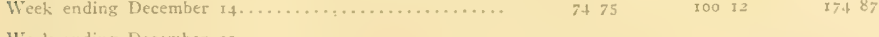

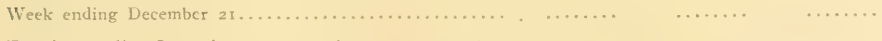

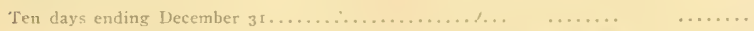


Payroli Schedule No. i 4 B.

DEPARTMENT OF PARKS, BOROUGH OF THE BRONX.

Statement shoreving payroll payments during 1906 for hired tcams, horses and carts, from Special Revenue Bond Fund, "Care of Trees in City Strects":

Period Ending.

1026 .

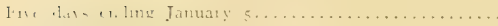

Whek ending January 12.

Theek ending January ig

Wish \& T lu.g Iistuas?

Weeh ot hift lebruar?

With whiss Felimary

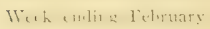

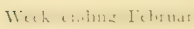

Welv enlute Marde =

Wieti endine Marelt a

Week ending March I6

Week ending March 23

Week ending March 30

Wiek andest bril t.

Wiak amlak Ipril 13.

Week ending $\Lambda$ pril 2

Wieek ending April 27

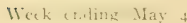

Week exitns May

Week ending May is

Wiek anling May :

Wiech coulutit Inne i

Weeh enderts Jume :

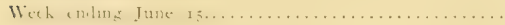

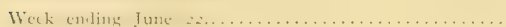

Week ending June 29

Wich thling Iuly (

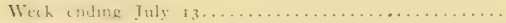

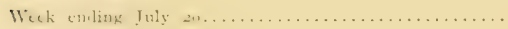

Wech crumg July $2, \ldots \ldots \ldots \ldots \ldots \ldots \ldots \ldots \ldots \ldots \ldots \ldots$
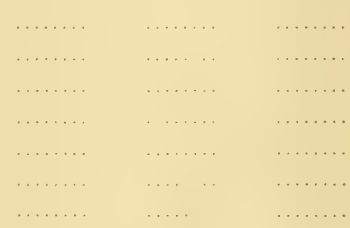

.......

$\ldots \ldots$
$\ldots \ldots$

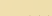
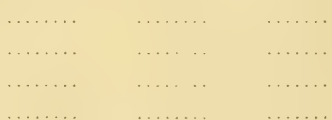

.....

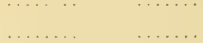

. $2 \ldots$

$\ldots \ldots$

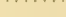

......

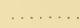

$\ldots$

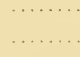

$\ldots \ldots$

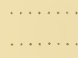

.......
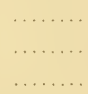

.......
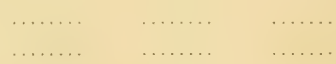


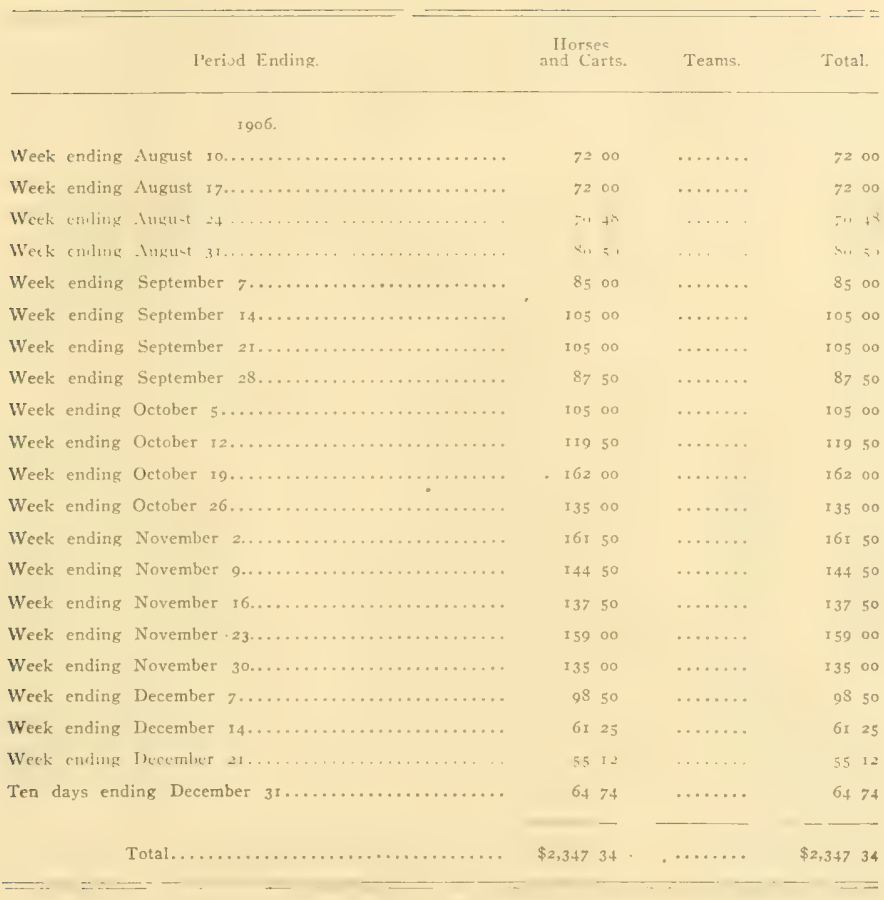


Payroli. SCHEdUle No. I513.

DEPARTAENT OF PARKS, BOROUGH OF THE BRONX.

Statement showing payroll payments during 1906 for hired tcams, horses and carts, from Corporate Stack Funds for the Construction and Improz'cment of Parks, Parkatu's, Boulerards, Drives, cte.:

$=$

Period Ending.

1906

Five days ending January 5 .

Week ending January $x 2 \ldots \ldots \ldots \ldots \ldots \ldots \ldots \ldots \ldots$

Week (nhlum famati is

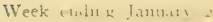

Week ending liebruary $2 . \ldots \ldots$

Week ending February $9 \ldots \ldots \ldots \ldots \ldots \ldots \ldots \ldots \ldots \ldots$

Weck ending February $16 \ldots \ldots \ldots \ldots \ldots \ldots \ldots \ldots \ldots$

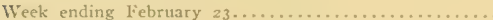

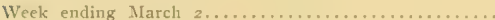

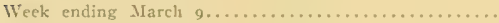

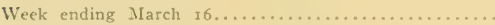

Weet ending March $23 \ldots \ldots \ldots \ldots \ldots \ldots \ldots \ldots \ldots . \ldots \ldots \ldots$

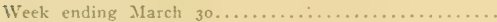

Week ending $\mathrm{ipril} 6 \ldots \ldots \ldots \ldots \ldots \ldots \ldots \ldots \ldots \ldots \ldots \ldots \ldots \ldots \ldots$

Week ending April r $3 \ldots \ldots \ldots \ldots \ldots \ldots \ldots \ldots \ldots \ldots \ldots$

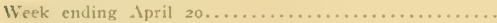

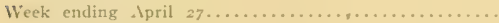

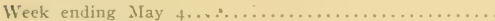

Weck ending May 1 M. . . . . . . . . . . . . . .

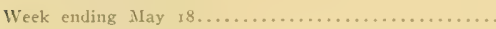

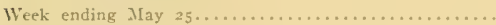

Week ending June $1 \ldots \ldots \ldots \ldots \ldots \ldots \ldots \ldots \ldots \ldots \ldots$

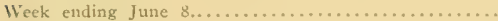

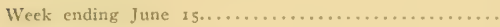

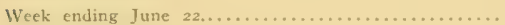

Week ending June $29, \ldots \ldots \ldots \ldots \ldots \ldots \ldots \ldots \ldots \ldots$

Week ending July $6 \ldots \ldots \ldots \ldots \ldots \ldots \ldots \ldots \ldots$

Week ending July $13 \ldots \ldots \ldots \ldots \ldots \ldots \ldots \ldots \ldots \ldots$

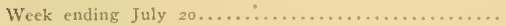

Week ending July 27 .
Ilorses

and Carts.

Teams.

Total.

$\begin{array}{rrrr}\$ 10125 & \$ 41987 & \$ 52112 \\ 15148 & 57618 & 72766\end{array}$

.....

\begin{tabular}{|c|c|c|c|c|}
\hline 75 & 00 & 450 & 00 & 120 \\
\hline 141 & 00 & 1327 & 75 & 273 \\
\hline 153 & oo & I $35 \mathrm{C}$ & 00 & . 288 \\
\hline$\cdots$ & $\cdots$ & I5 53 & 00 & I 53 \\
\hline 190 & 50 & 1845 & 50 & 375 \\
\hline 156 & 00 & $1 S_{4} 5$ & 50 & $3+0$ \\
\hline 226 & 00 & $336=$ & 37 & 462 \\
\hline 39 & 75 & 2137 & 73 & 253 \\
\hline 96 & oo & $33^{8}$ & 62 & 434 \\
\hline I 59 & 00 & 500 & 62 & 659 \\
\hline 162 & 75 & 823 & 98 & 986 \\
\hline 172 & 50 & 9315 & 50 & 1,104 \\
\hline 204 & 00 & 8.406 & 61 & 1,044 \\
\hline 87 & $\infty$ & $704=$ & 24 & 791 \\
\hline 62 & 62 & 763 & 73 & 826 \\
\hline 60 & 00 & 643 & 50 & 203 \\
\hline 249 & 00 & $1,032=$ & 74 & $\mathrm{I}, 28 \mathrm{I}$ \\
\hline 148 & 50 & 810 & 68 & 959 \\
\hline 194 & 25 & 940 & 50 & 1,134 \\
\hline 198 & 00 & 818 & 00 & 1,016 \\
\hline 130 & 59 & 658 & 69 & 789 \\
\hline 185 & 99 & 930 & 92 & $1,1 \geq 6$ \\
\hline 165 & 00 & 802 & 68 & 967 \\
\hline 387 & 50 & 969 & 50 & 1,157 \\
\hline 227 & 09 & 965 & 65 & 1,192 \\
\hline 185 & 62 & 967 & 28 & 1,152 \\
\hline
\end{tabular}




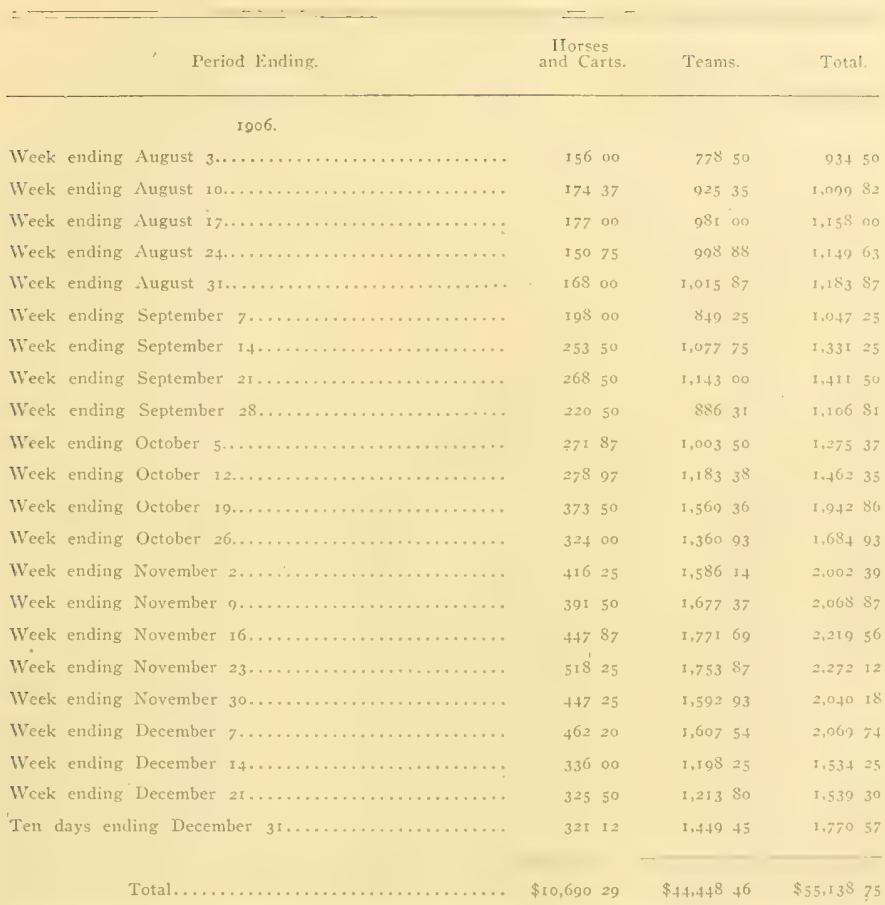


Payroll Schedule No. i6B.

\section{DEPARTMENT OF PARKS, BOROUGH OF THE BRONA.}

Summary showing payroll pajments during 1906 for hired tcams, horses and carts. ctc., charged against all Budget, Spccial Rezenue Bond and Corporate Stock Accounts:

\begin{tabular}{|c|c|c|c|c|}
\hline Period Ending & $\begin{array}{c}\text { From } \\
\text { Budget } \\
\text { Appropria- } \\
\text { tions. }\end{array}$ & $\begin{array}{l}\text { From } \\
\text { Revenue } \\
\text { Bond } \\
\text { Accounts. }\end{array}$ & $\begin{array}{l}\text { From } \\
\text { Corporate } \\
\text { Stock } \\
\text { Accounts. }\end{array}$ & $\begin{array}{l}\text { From } \\
\text { All } \\
\text { Accounts }\end{array}$ \\
\hline I906. & & & & \\
\hline Five days ending January $5 \ldots \ldots \ldots \ldots \ldots$ & $\$ 70800$ & $\cdots \cdots$ & $\$ 521 \quad 12$ & $\$ 1,31912$ \\
\hline Week ending January $12 \ldots \ldots \ldots \ldots \ldots \ldots$ & 1,16475 & $\cdots \cdots$ & 72766 & $1,892 \quad 42$ \\
\hline 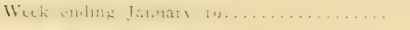 & $\ldots \ldots$ & … & - . . & . $\ldots . .$. \\
\hline 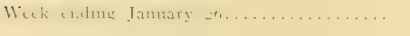 & $\cdots \cdots$ & & $\cdots$ & $\cdots \cdot$ \\
\hline Week ending February $2 \ldots \ldots \ldots \ldots \ldots$ & 3000 & $\cdots \cdots$ & 82000 & I50 of \\
\hline Week ending February $9 \ldots \ldots \ldots \ldots \ldots$ & I8 00 & $\cdots \cdots$ & 27375 & 29175 \\
\hline Week ending February $16 \ldots \ldots \ldots \ldots \ldots$ & 2700 & $\cdots \cdots$ & 28800 & 315 or \\
\hline Week ending February $23 \ldots \ldots \ldots \ldots \ldots$ & 2700 & $\cdots \cdots$ & 15300 & 180 or \\
\hline Week ending Mareh $2 \ldots . . . \ldots .$. & 3700 & $\cdots \cdots$ & 37500 & 402 of \\
\hline Week ending March $9 . \ldots \ldots \ldots \ldots \ldots \ldots$ & $2+75$ & $\cdots \cdots$ & 34050 & 36525 \\
\hline Week ending March I6....... & 5100 & $\cdots \cdots$ & 46237 & $5+33:$ \\
\hline Week ending March $23 \ldots \ldots \ldots \ldots \ldots \ldots$ & 4200 & $\cdots \cdots$ & 25348 & 29548 \\
\hline Week ending March $30 \ldots$. & 4500 & $\cdots \cdots$ & $43+62$ & 4796 \\
\hline Week ending April $6 \ldots . .$. . & 4500 & $\cdots \cdots$ & 65962 & $70+6$ \\
\hline Week ending April r $3 \ldots \ldots \ldots \ldots \ldots \ldots \ldots$ & 21635 & $\cdots \cdots$ & 98673 & 1,203 of \\
\hline Week ending April 20... & 33300 & $\cdots \cdots$ & $x, 10400$ & 1,437 of \\
\hline Week ending April $27 \ldots$. & 40346 & $\cdots \cdots$ & 1,04461 & $1,4+48$ o \\
\hline Week ending May $4 \ldots$. . & 94999 & $\cdots \cdots$ & 79024 & $1,7+12$ \\
\hline Week ending May Ix..... & Sor 84 & $\cdots \cdots$ & 82635 & $x, 628$ is \\
\hline Week ending May $18 \ldots . .$. & $910 \quad 12$ & $\cdots \cdots$ & 70350 & 3,6136 \\
\hline Week ending May $25 \ldots \ldots \ldots \ldots \ldots \ldots \ldots$ & 73575 & $\cdots \cdots$ & $1,28 \mathrm{I} 74$ & 2,0174 \\
\hline Week ending June $1 . . . \ldots \ldots \ldots \ldots \ldots . . . .$. & $7+097$ & $\cdots \cdots$ & 95918 & 1,7001 \\
\hline Week ending June $8, \ldots .$. & 99900 & $\cdots \cdots$ & 1,13475 & 2,1337 \\
\hline Week ending June $15, \ldots \ldots \ldots \ldots \ldots \ldots \ldots$ & $1,007 \quad 25$ & $\cdots \cdots$ & 1,01600 & 2,0232 \\
\hline Week ending June $22, \ldots \ldots \ldots \ldots \ldots \ldots$ & 76784 & $\cdots \cdots$ & $789 \quad 28$ & $x, 557 \times$ \\
\hline Week ending June $29 \ldots \ldots \ldots \ldots \ldots$ & 1,10325 & $\cdots \cdots$ & $1,1169 \mathrm{I}$ & 2,220 I \\
\hline Week ending July $6 \ldots \ldots \ldots \ldots \ldots \ldots \ldots$ & 46500 & $\$ 529 \quad 50$ & 96768 & $\mathrm{x}, 962 \mathrm{I}$ \\
\hline Week ending July $13 \ldots \ldots \ldots \ldots \ldots \ldots$ & 53850 & 63750 & $x, 15700$ & $2,333 \circ$ \\
\hline Wheek ending Jaly $20, \ldots \ldots \ldots \ldots \ldots \ldots$ & 55978 & 70416 & 1,19274 & $2,456 \quad 6$ \\
\hline Week ending July $27 \ldots \ldots \ldots \ldots \ldots \ldots$ & $503 \quad 57$ & 71100 & 1,15290 & $2,367,4$ \\
\hline
\end{tabular}




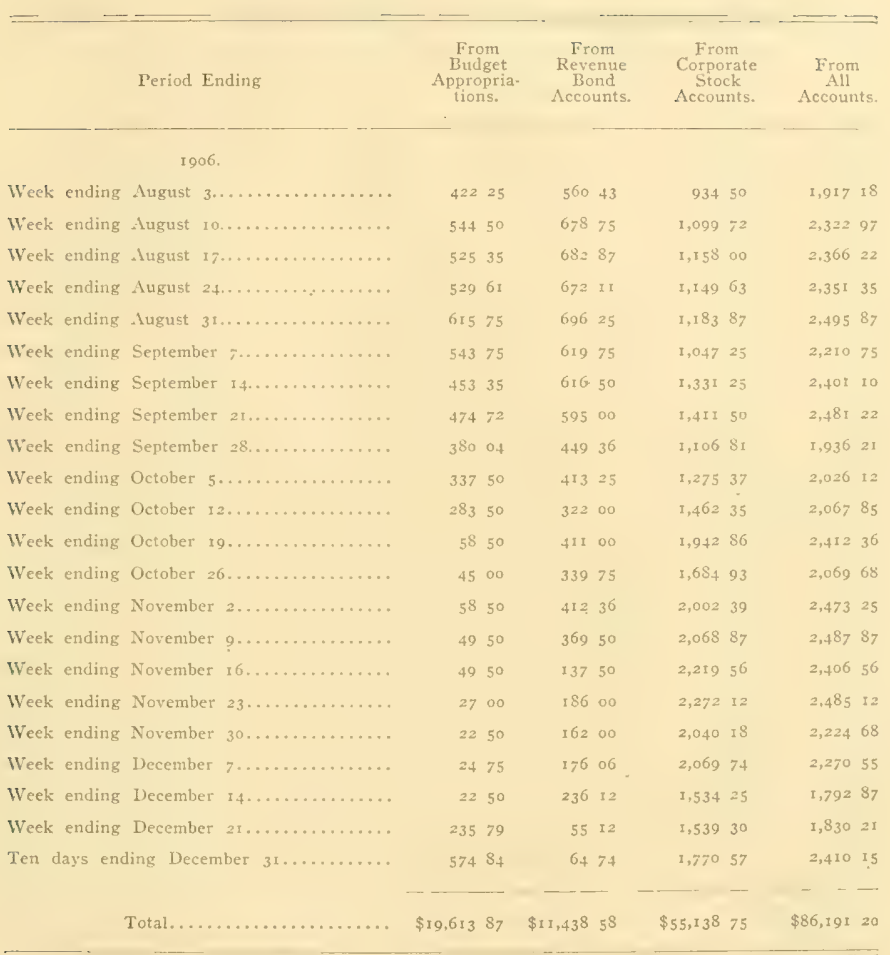


Pajkoll Schedule No. i7B.

DIPARTMENT OF PARKS, BOROUGH OF THE IBRONX.

Showing payroll paymonts, January i to August 30, 1907, for hired teams, horses and carts, charged against Budget Appropriation Account, Maintenance and Construction:

Period Ending

1907.

Four days ending January + ta

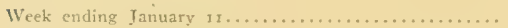

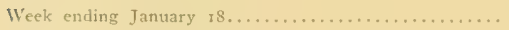

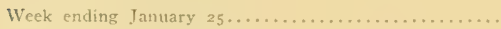

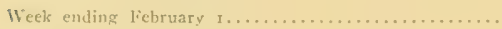

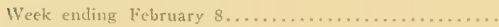

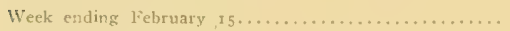

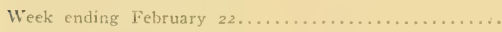

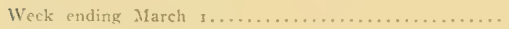

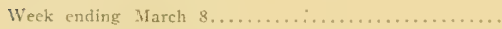

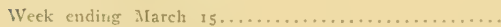

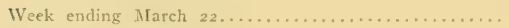

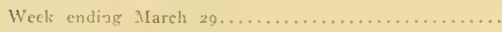

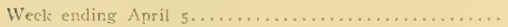

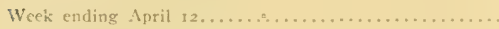

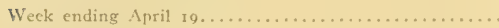

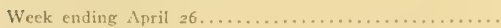

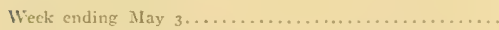

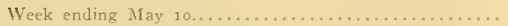

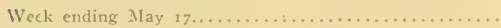

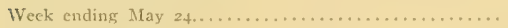

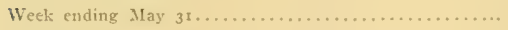

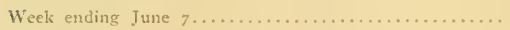

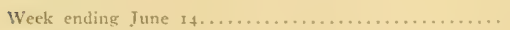

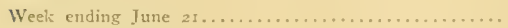

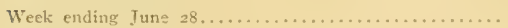

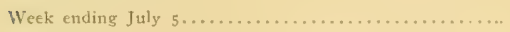

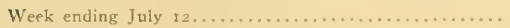

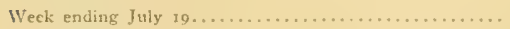

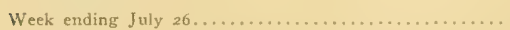

Hirses
and Carts.

Teams.

Total.

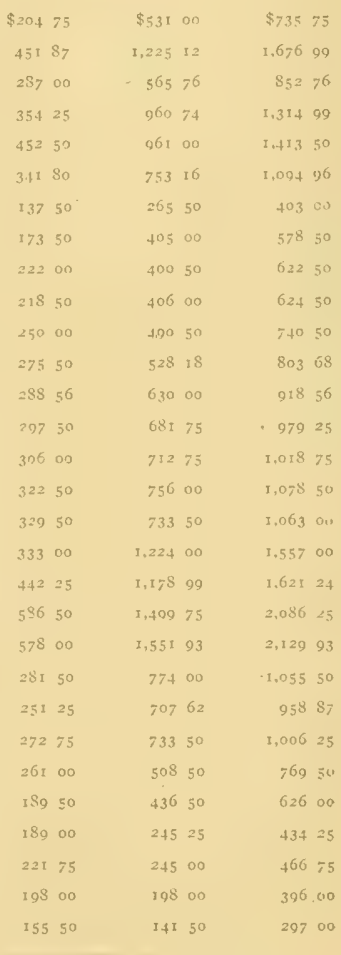




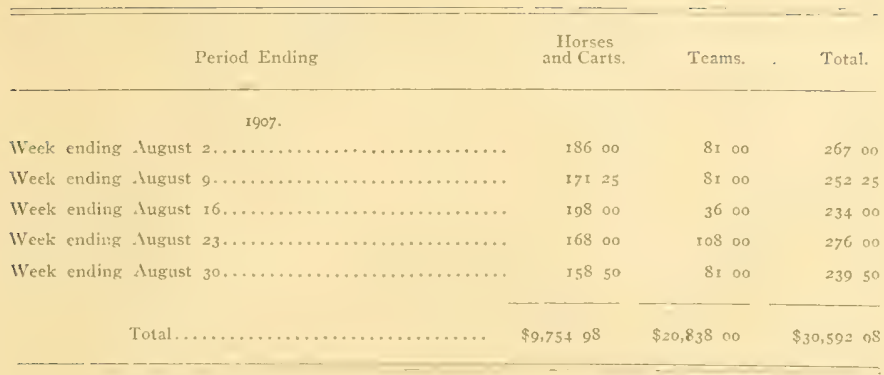

Payroll Schedule No. isB.

DEPARTMENT OF PARKS, BOROUGH OF THE BRONX.

Showing payroll paymonts, January I to August 30, 1907, for hired teans, horses and carts, charged against Budget Appropriation Account, Forestry Work:

\begin{tabular}{|c|c|c|c|}
\hline Period Ending. & $\begin{array}{l}\text { Horses } \\
\text { and Carts. }\end{array}$ & Teams. & Total. \\
\hline 1907. & & & \\
\hline Fonr days ending January $4 \ldots \ldots \ldots \ldots \ldots \ldots \ldots \ldots \ldots \ldots$ & $\ldots \ldots \ldots$ & $\$ 1350$ & $\$ 135 n$ \\
\hline Week ending January is.... & $\ldots \ldots \ldots$ & 1800 & 18 on \\
\hline We k embing Janualy is........ & $\cdots \cdots \cdots$ & $45+$ & 45 \\
\hline Weck ending January $25 \ldots \ldots \ldots \ldots \ldots \ldots \ldots \ldots \ldots \ldots \ldots$ & ........ & 2250 & 2250 \\
\hline Weak collus Februaty t.... & & $\ldots \ldots \ldots$ & . . . . . \\
\hline Weck emline lelorway s, .............. & $\cdots$ & . $\cdots \cdots$ & $\cdots \cdot$ \\
\hline Week enting February $1=$. & & $\cdots \cdots \cdots$ & $\cdots$ \\
\hline Werk cmoling lebruars $\therefore$... & & . $\cdots \cdots$ & ........ \\
\hline Week emilung Mareli 1 ........ & n..... & $\ldots \ldots \ldots$ & $\cdots \cdots$ \\
\hline 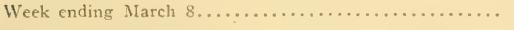 & . $\ldots \ldots$ & $\ldots \ldots \ldots$ & $\cdots \cdots$ \\
\hline 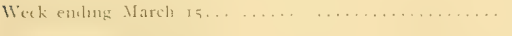 & $\ldots \ldots \ldots$ & $\ldots \ldots \ldots$ & $\ldots \ldots \ldots$ \\
\hline 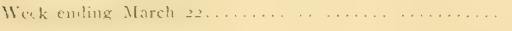 & $\ldots \ldots \ldots$ & . $\ldots \ldots$ & $\ldots \ldots$ \\
\hline Wek (molng March it).... & & $\cdots \cdots$ & $\ldots \ldots$ \\
\hline 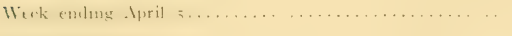 & $\ldots \ldots \ldots$ & …... & . . . . \\
\hline 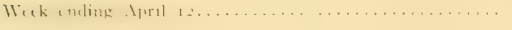 & & $\ldots \ldots$ & ... \\
\hline 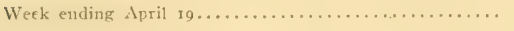 & ........ & $\ldots \ldots \ldots$ & ........ \\
\hline Week ending $\lambda_{\text {pril }} 26 \ldots \ldots \ldots \ldots \ldots \ldots \ldots \ldots \ldots \ldots \ldots \ldots \ldots \ldots \ldots \ldots$ & $\ldots \ldots \ldots$ & 1350 & 1350 \\
\hline 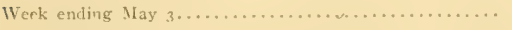 & $\ldots \ldots \ldots$ & 1575 & 1575 \\
\hline
\end{tabular}




\begin{tabular}{cccc}
\hline Period Ending & $\begin{array}{c}\text { Horses } \\
\text { and Carts, }\end{array}$ Teams. & Total. \\
Mr. & &
\end{tabular}

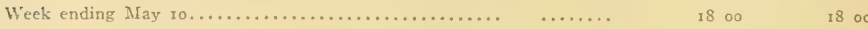

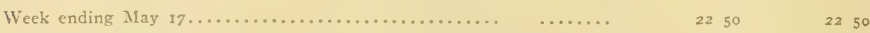

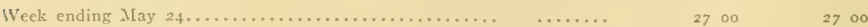

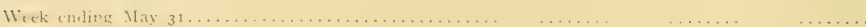

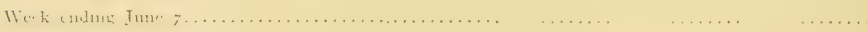

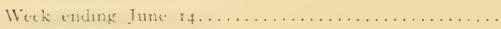

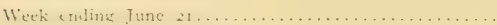

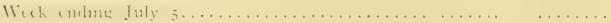

Wien enlug Tuly 12

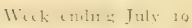

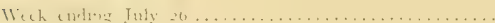

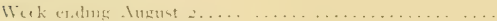

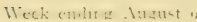

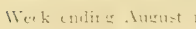

Week ending August 23

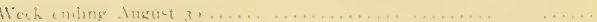

r.tal.

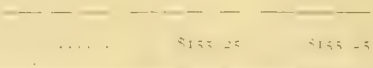

Payroll Schedtle No, igli

DEPARTMENT OF PARKS, BOROUGH OF THE BRONX.

Shozing payroll payments, January I to Augusi 30, 1907, for hired teams, horses and carts, charged against Budget Appropriation Account, Care of Trees in City Streets:

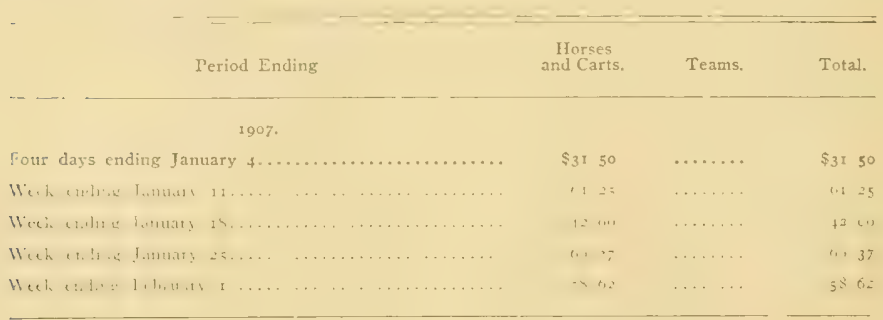




\begin{tabular}{|c|c|c|c|}
\hline Period Ending & $\begin{array}{c}\text { Horses } \\
\text { and Carts. }\end{array}$ & Teams. & Total. \\
\hline 1907. & & & \\
\hline 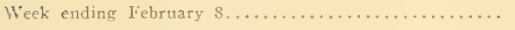 & 28 no & $\ldots \ldots \ldots$ & 2800 \\
\hline Week ending February $15 \ldots \ldots \ldots \ldots \ldots \ldots \ldots \ldots \ldots \ldots \ldots \ldots \ldots \ldots$ & Io 50 & $\cdots \cdots \cdots$ & to 50 \\
\hline Week ending February $22 \ldots \ldots \ldots \ldots \ldots \ldots \ldots \ldots \ldots \ldots \ldots \ldots \ldots \ldots \ldots \ldots \ldots$ & $2 \pi 00$ & ........ & 2100 \\
\hline 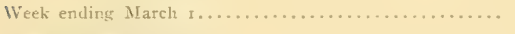 & I4 00 & $\ldots \ldots \ldots$ & 1400 \\
\hline 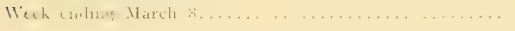 & $1+\ldots$ & $\ldots \ldots$ & $2+m+1$ \\
\hline 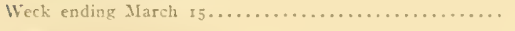 & 2500 & $\ldots \ldots \ldots$ & 2100 \\
\hline 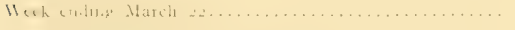 & $\therefore \quad$, & $\ldots \ldots \ldots$ & $-1<0$ \\
\hline 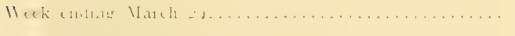 & $\therefore \ldots$ & $\cdots \cdots$ & $\therefore \leqslant$ \\
\hline 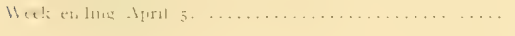 & $\therefore \ldots$ & $\cdots \cdots \cdots$ & $-1 \quad \cdots$ \\
\hline Week ending April r $2, \ldots \ldots \ldots \ldots \ldots \ldots \ldots \ldots \ldots \ldots \ldots \ldots \ldots$ & 2100 & ........ & $2 \mathrm{I} 00$ \\
\hline Week ending April $19 \ldots \ldots \ldots \ldots \ldots \ldots \ldots \ldots \ldots \ldots \ldots \ldots \ldots \ldots$ & 1750 & $\ldots \ldots \ldots$ & 1750 \\
\hline 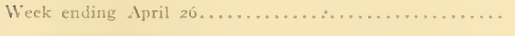 & 2100 & $\cdots \cdots$ & 2100 \\
\hline Wieh ending May $3 \ldots \ldots \ldots$. & $1-\ldots$ & $\cdots \quad \cdots$ & $+3 \quad 13$ \\
\hline 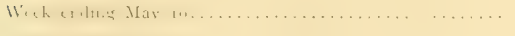 & $3 \cdots$ & $\cdots \ldots \ldots$ & 354 \\
\hline 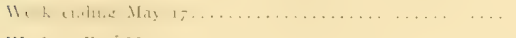 & if t 2 & ........ & ti 12 \\
\hline 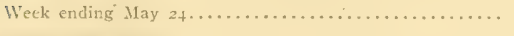 & 4200 & $\cdots \cdots \cdots$ & 4200 \\
\hline 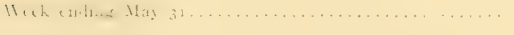 & $1=\ldots$ & $\ldots \ldots$ & +260 \\
\hline Week ending June $7 \ldots \ldots \ldots$. & 5600 & $\cdots \cdots \cdots$ & 5600 \\
\hline 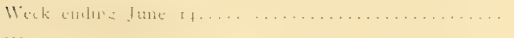 & $6,3 \cdots$ & & $\because \cdot$ \\
\hline Week ending June $21 \ldots \ldots \ldots \ldots \ldots \ldots \ldots \ldots \ldots \ldots \ldots \ldots \ldots \ldots \ldots$ & 5075 & …... & 5075 \\
\hline 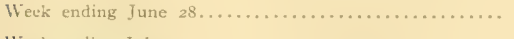 & 5950 & ….... & 5950 \\
\hline 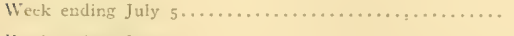 & 5075 & $\cdots \cdots \cdots$ & 5075 \\
\hline 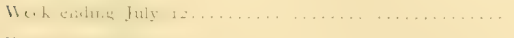 & (1; $\cdots \cdot$ & $\cdots \cdots$ & 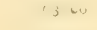 \\
\hline 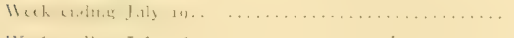 & $\therefore \cdots$ & $\cdots \cdots$ & $-\cdots u$ \\
\hline Week ending Jily $26 \ldots \ldots \ldots \ldots \ldots$ & 5250 & $\$ 3250$ & 7500 \\
\hline Week ending lugust $2 \ldots \ldots \ldots \ldots \ldots \ldots \ldots \ldots \ldots \ldots \ldots \ldots \ldots \ldots \ldots$ & 6300 & 2700 & $90 \quad 00$ \\
\hline Week ending August $9 \ldots \ldots \ldots \ldots \ldots \ldots \ldots \ldots \ldots \ldots \ldots \ldots$ & 1300 & 2700 & $90 \mathrm{cu}$ \\
\hline 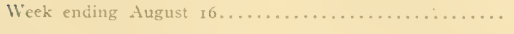 & 6,300 & 2700 & 9000 \\
\hline Week ending lugust $=3 \ldots \ldots \ldots \ldots \ldots \ldots \ldots \ldots \ldots \ldots \ldots$ & 6300 & 2700 & $90 \quad 00$ \\
\hline Week ending August $30 \ldots \ldots \ldots \ldots \ldots \ldots \ldots \ldots \ldots \ldots \ldots \ldots \ldots \ldots \ldots$ & 5775 & 2475 & 8250 \\
\hline Total.......... & $\$ 1,460 \quad 36$ & $\$ 155=5$ & $\$ 1,61561$ \\
\hline
\end{tabular}


Payroll Schedtle No. 2013.

DEPARTMENT OF PARKS, BOROUGH OF THE BRONX.

Showing payroll paymcnts, January $x$ to August 3I, 1907, for hircd tcams, horses and carts, charged against Corporatc Stock Accounts, for Construction of Parks, Parkways, Boulciards, Driz'cs, ctc.:

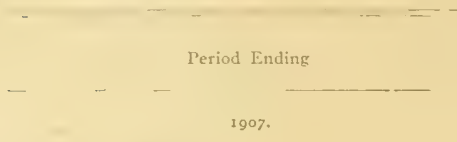

Four days ending January

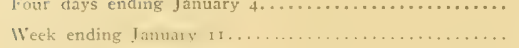

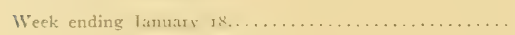

Week ending I anuary $25 \ldots \ldots \ldots \ldots \ldots \ldots \ldots \ldots \ldots \ldots$

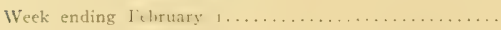

Week ending likhmary $\ldots \ldots \ldots \ldots \ldots \ldots \ldots \ldots \ldots \ldots$

Week ending lebrusty $15 \ldots \ldots \ldots \ldots \ldots \ldots \ldots \ldots \ldots$

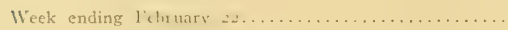

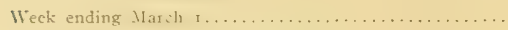

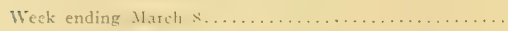

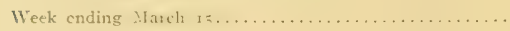

Week ending Marili $22 \ldots \ldots \ldots \ldots \ldots \ldots \ldots \ldots \ldots \ldots$

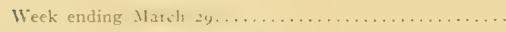

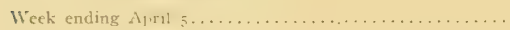

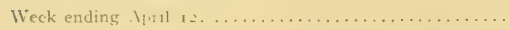

Week ending . Ipril rg.......................

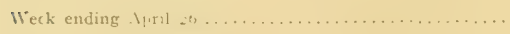

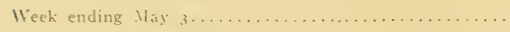

Horses

and Carts.

Teams.

Total.

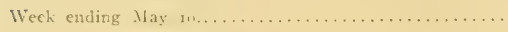

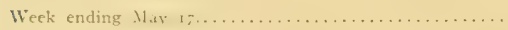

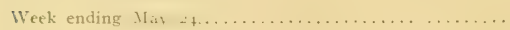

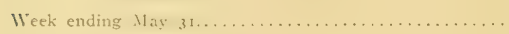

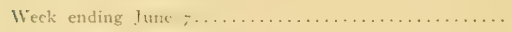

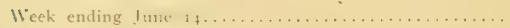

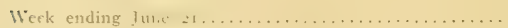

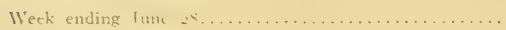

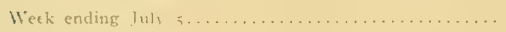

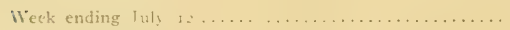

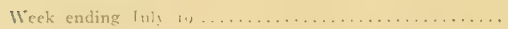

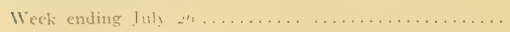

\begin{tabular}{|c|c|c|c|c|}
\hline$\$ 72$ & 00 & $\$ 456$ & 75 & $\$ 528$ \\
\hline 105 & 00 & $78 \mathrm{I}$ & 99 & 886 \\
\hline 56 & 25 & 308 & 47 & 364 \\
\hline 108 & 00 & 614 & 25 & 722 \\
\hline 93 & 00 & 501 & 75 & 594 \\
\hline 33 & 00 & 209 & 25 & 282 \\
\hline 18 & oo & I 48 & 50 & 166 \\
\hline 9 & 00 & 27 & 00 & 36 \\
\hline 9 & 00 & 54 & 00 & $6_{3}$ \\
\hline 6 & oo & 49 & 50 & 55 \\
\hline 3 & eo & 27 & oo & 30 \\
\hline 9 & 00 & 27 & 00 & 36 \\
\hline$\cdots$ & $\cdots$ & 27 & 00 & 27 \\
\hline$\cdots$ & $\cdots$ & 27 & 00 & 27 \\
\hline$\cdots$ & $\cdots$ & 27 & 00 & 27 \\
\hline$\cdots \cdots$ & $\cdots$ & 27 & 00 & 27 \\
\hline$\cdots \cdots$ & $\cdots$ & 27 & 00 & 27 \\
\hline 18 & 00 & 103 & 50 & 121 \\
\hline$\ldots$ & $\cdots$ & $\ldots \ldots$ & $\cdots$ & $\ldots$ \\
\hline$\cdots \cdots$ & $\cdots$ & $\cdots \ldots$ & & \\
\hline 18 & $\infty 0$ & I 57 & 50 & 175 \\
\hline 276 & oo & 1,070 & 75 & 1,346 \\
\hline 277 & so & $9+2$ & 74 & 1,220 \\
\hline 283 & 50 & 930 & 62 & 1,214 \\
\hline 291 & 50 & I. $3^{6}{ }_{3}$ & 50 & 1,655 \\
\hline 332 & 50 & 1,375 & 27 & 1,707 \\
\hline 297 & $50^{\circ}$ & 1,356 & 00 & 1,653 \\
\hline 341 & 50 & 1.590 & 62 & 1,932 \\
\hline 473 & oo & 1,716 & $8 \pi$ & 2,189 \\
\hline 3.31 & 50 & 1.365 & 75 & 1,697 \\
\hline
\end{tabular}




\section{$8 I$}

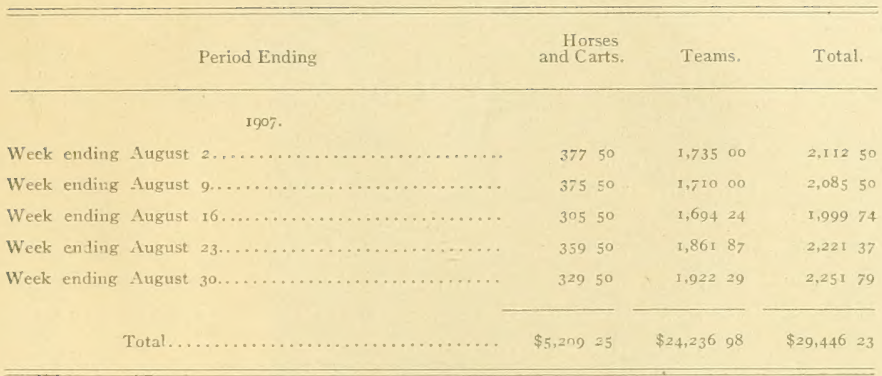

Payroll Schedule No. $2 \mathrm{iB}$.

\section{DEPARTMENT OF PARKS, BOROUGH OF THE BRONX.}

Summary showing payroll payments, January I to August 30 , 1907, for hired teams, "horses and carts, charged against Budget Appropriation and Corporate Stock Accounts:

\begin{tabular}{|c|c|c|c|}
\hline Period Ending & $\begin{array}{c}\text { From } \\
\text { Budget } \\
\text { Appropria- } \\
\text { tions. }\end{array}$ & $\begin{array}{c}\text { From } \\
\text { Corporate } \\
\text { Stock } \\
\text { Accounts. }\end{array}$ & $\begin{array}{c}\text { Grand } \\
\text { Total, } \\
\text { All } \\
\text { Accounts. }\end{array}$ \\
\hline Four days ending January 4 . & $\$-80=5$ & & $5 x=300-5$ \\
\hline Week ending January $x \mathrm{x}, \ldots$ & $x, 75624$ & 88699 & $2,643 \quad 23$ \\
\hline Week ending January $18 \ldots$ & 89926 & 36472 & 1,26398 \\
\hline Week ending January $25 \ldots \ldots \ldots \ldots \ldots \ldots \ldots \ldots \ldots \ldots \ldots \ldots \ldots$ & 1,39786 & $722 \quad 25$ & $2,120 \quad 11$ \\
\hline Week ending February r..... & $x, 472 \quad 12$ & 59475 & 2,06687 \\
\hline Week ending February $8 \ldots$. & 1,12296 & 24225 & 1,36521 \\
\hline Week ending February $15 \ldots$. & 41350 & 16650 & 580 oo \\
\hline Week ending February $22 \ldots \ldots \ldots \ldots \ldots \ldots \ldots \ldots \ldots \ldots \ldots \ldots \ldots \ldots$ & 59950 & 36 oo & 63550 \\
\hline Week ending March $1, \ldots \ldots$. & 63650 & 6300 & 69950 \\
\hline Week ending March $8 \ldots \ldots \ldots$. & 63850 & 5550 & 69400 \\
\hline Week ending March $15 \ldots .$. & 76150 & 30 oo & 79150 \\
\hline 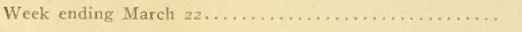 & 82468 & 3600 & 86068 \\
\hline Week ending March $29 . . . \ldots$. & 93956 & 2700 & 96656 \\
\hline Week ending April $5 \ldots . .$. & $\mathrm{I}, 00025$ & 2700 & 1,02725 \\
\hline Week ending April 12.... & 1,03975 & 2700 & 1,06675 \\
\hline Week ending April $19 \ldots \ldots \ldots \ldots \ldots \ldots . . . . .$. & 1,096 oo & 2700 & 1,12300 \\
\hline Week ending April $26 \ldots \ldots \ldots \ldots \ldots$ & 1,09750 & 2700 & 1,12450 \\
\hline
\end{tabular}




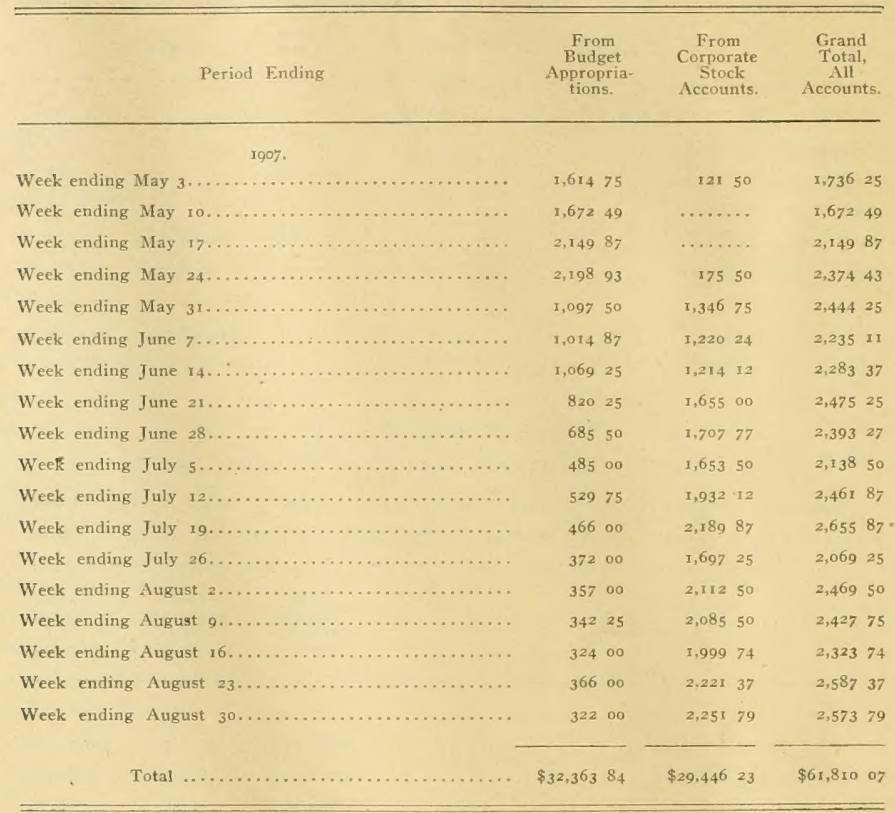




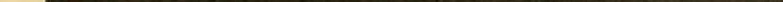


LIBRARY OF CONGRESS

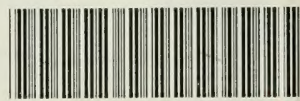

00030700107 